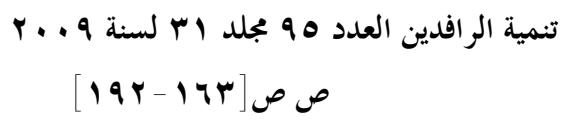

$$
\begin{aligned}
& \text { ساي محمد مقداد } \\
& \text { باحث اقتصادي - قسم الأبحاث والدراسات } \\
& \text { وزارة المالية }
\end{aligned}
$$

$$
\begin{aligned}
& \text { الدكتور محمد إيراهيم مقداد } \\
& \text { أستاذ مشارك في الاقتصاد- قسم الاقتصاد } \\
& \text { الجامعة الإسلامية- غزة }
\end{aligned}
$$

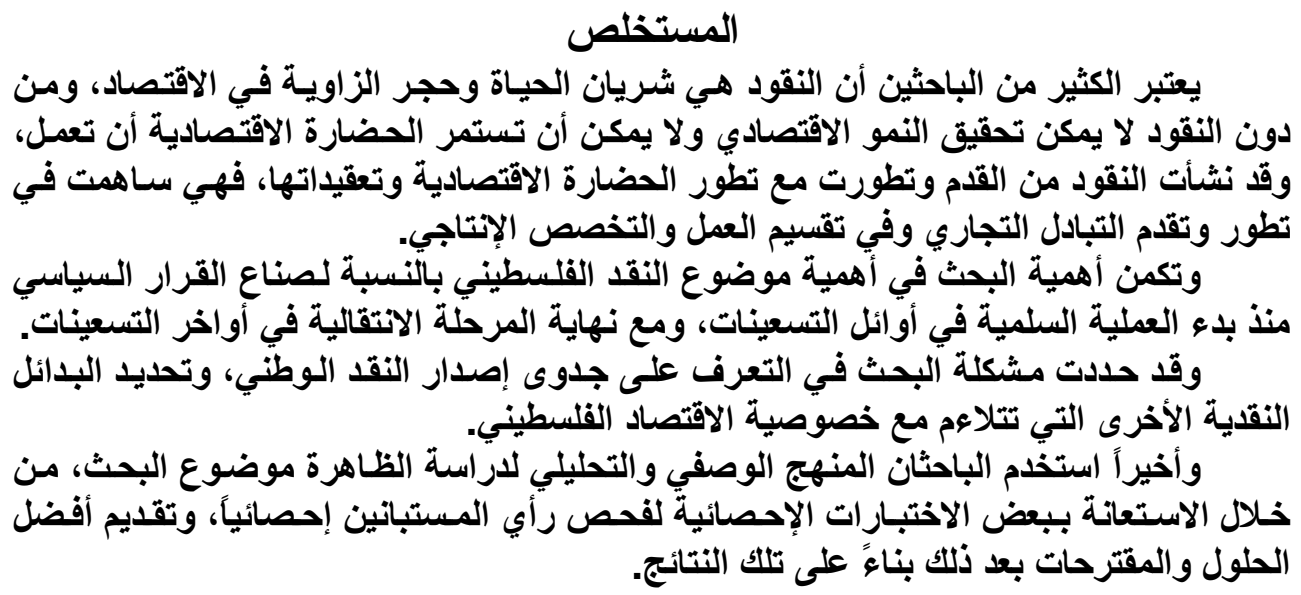

\title{
Release of National Funding in Palestine and the Available Substitutive Funding
}

\author{
Mohammed I. Mokdad (PhD) \\ Associate professor of Economics \\ Department of Economics \\ Islamic university - Gaza
}

\section{Sami M. Mokdad}

Economic Researcher

Department of Research and Studies

Ministry of Finance

\section{Abstract}

Many researchers consider money as the cornerstone of economy, without money growth can not be achieved and civilization can not be sustained as well. Money released during old ages and developed within the development of economic civilization and complexities of work and production system. The importance of the research has been presented in terms of Palestinian funds according to the political decision making since the

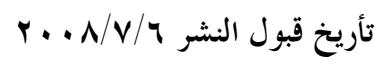

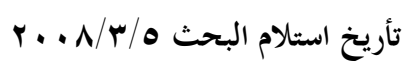


eve of peace process during 1970s and provisional operation during 1990s. The problem of the paper has been identified to show the schedule of national funding, and other available substitutive funding suitable for privacy of Palestinian economy. Descriptive and analytical approaches have been used to study this phenomenon. Statistical tests have been identified as well to examine the opinions and present the best solutions and suggestions.

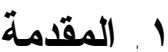

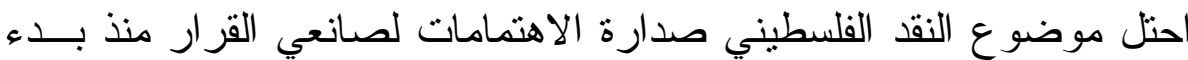

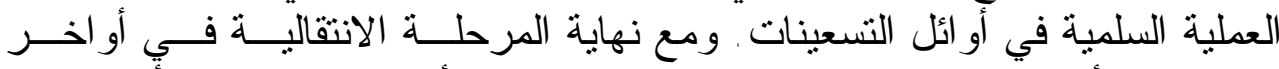

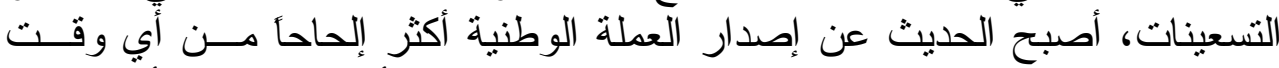

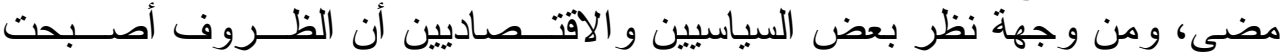

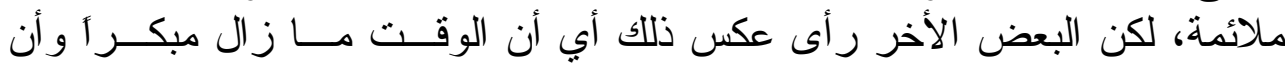

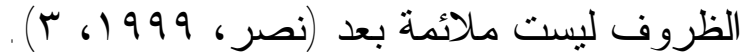

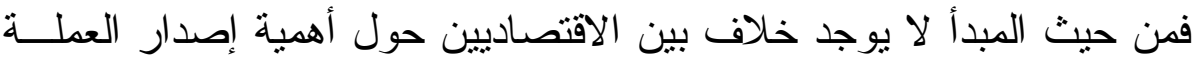

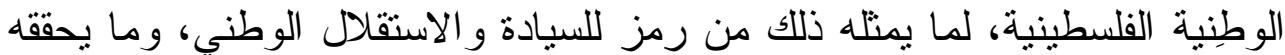

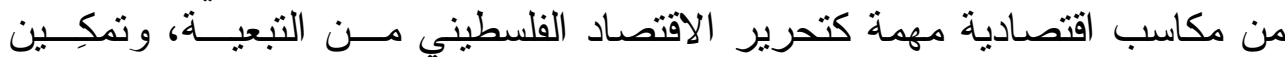

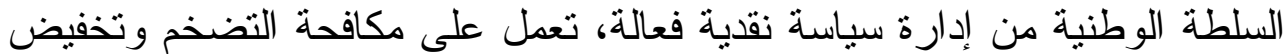

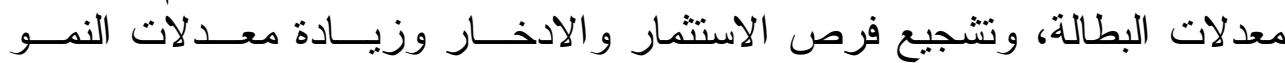
الاقتصادي في فلسطين.

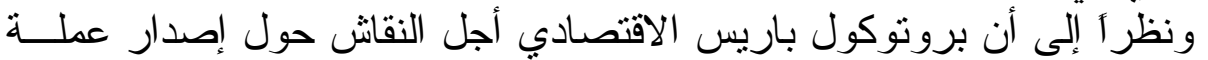

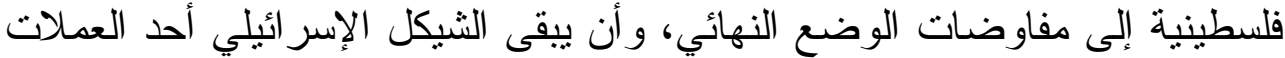

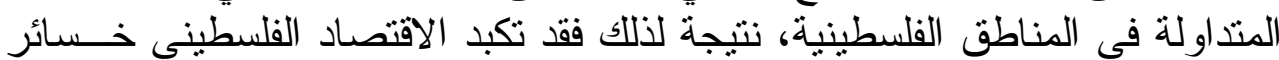

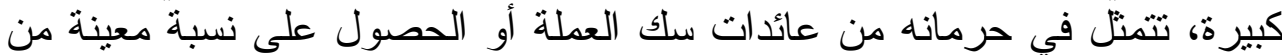

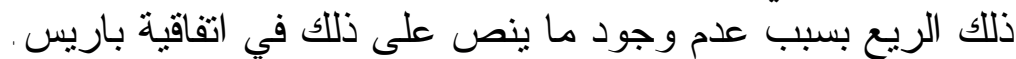

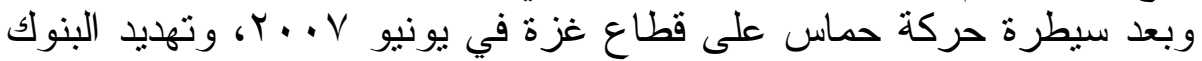

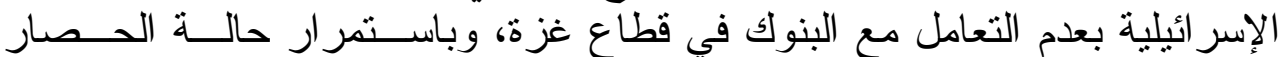

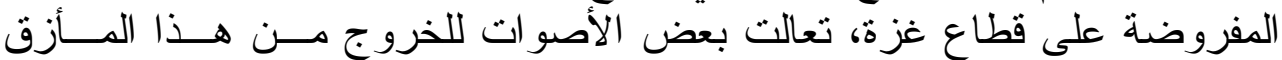

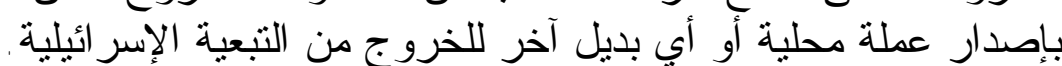

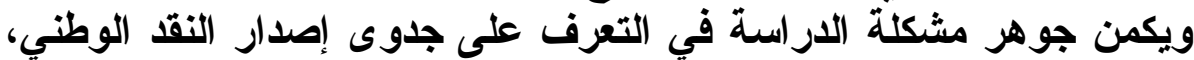

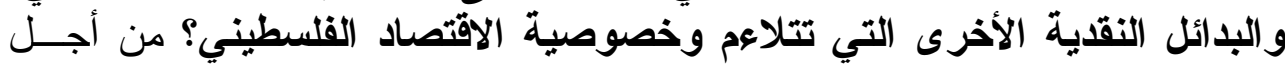

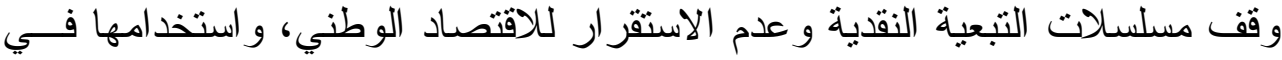

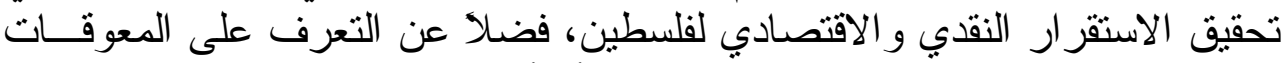

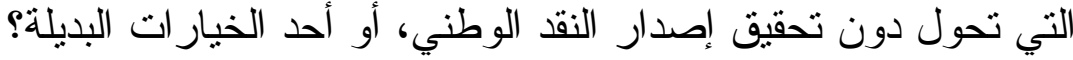

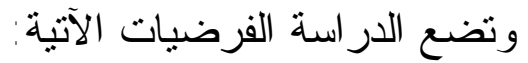

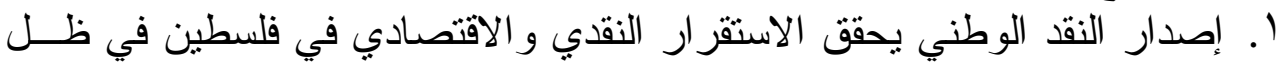
الأوضاع الحالية القائمة. r. توجد عدة بدائل تشهم في التغلب على مشكلة عدم إصدار نقد فلسطيني. 


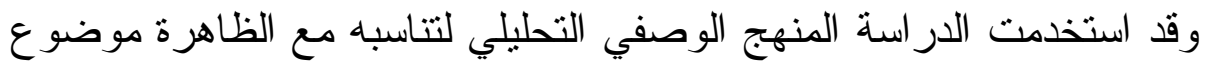

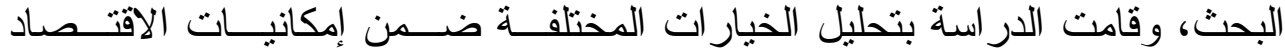

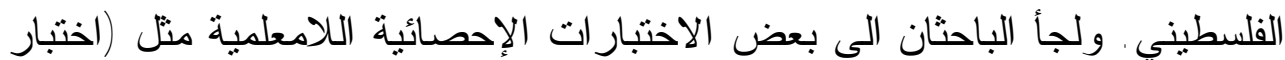

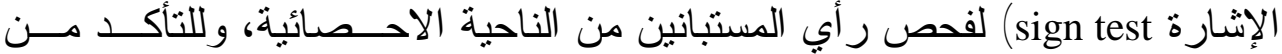

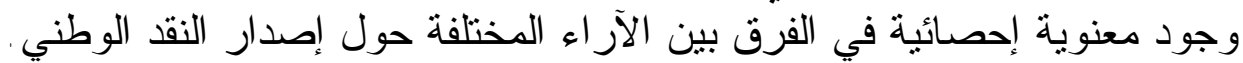

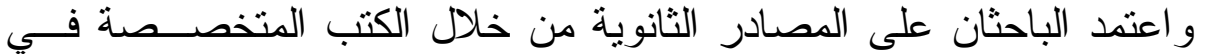

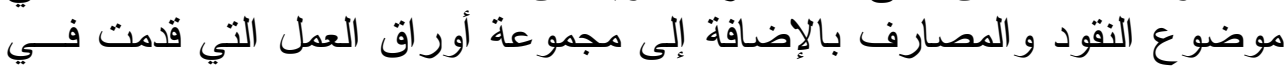

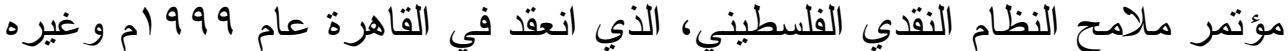

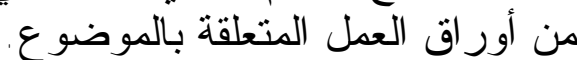

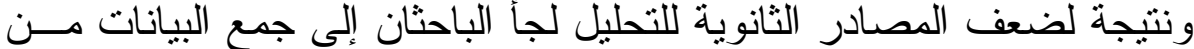

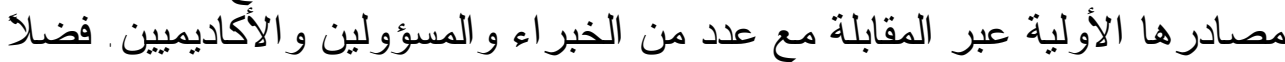

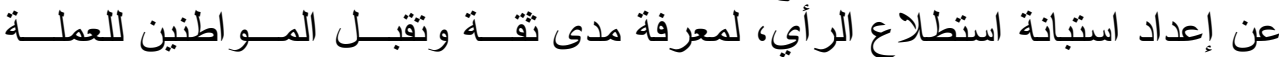

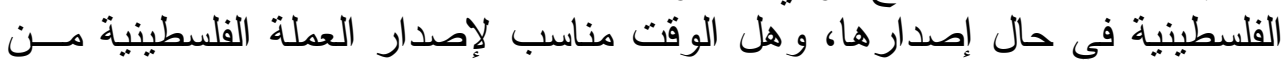

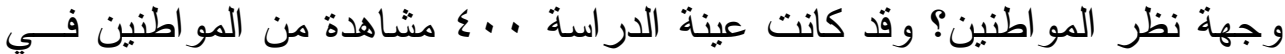
قطاع غزة، نم اختيار ها بطريقة صدفية.

\section{أولاً - مفهوم النقود و السياسة النقدية}

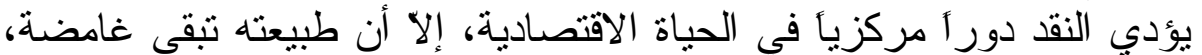

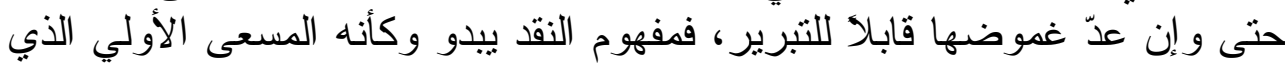

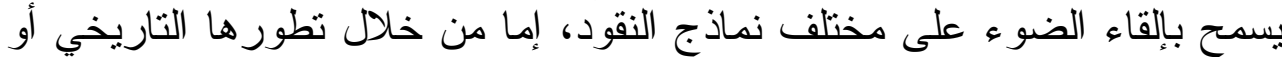

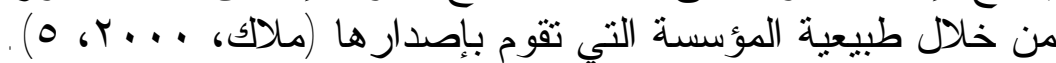

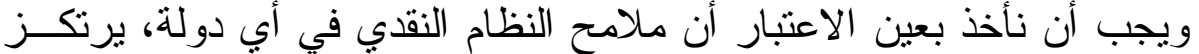

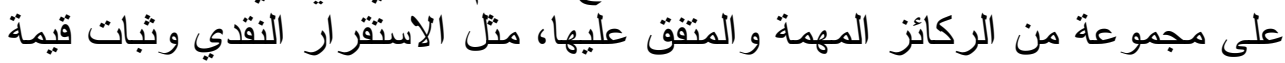

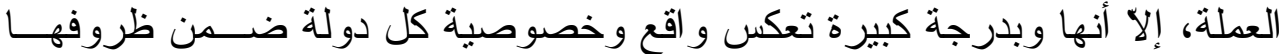

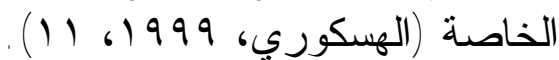

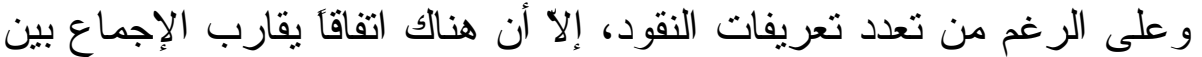

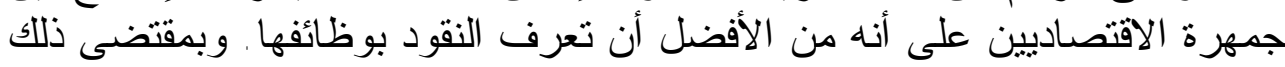

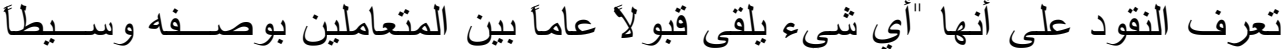

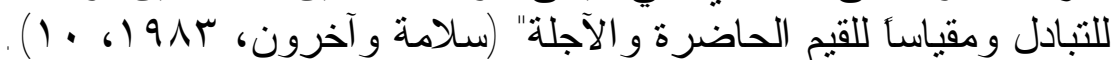

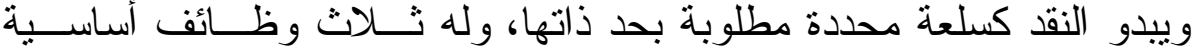

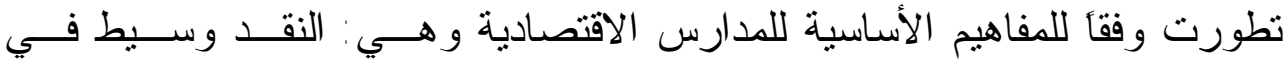

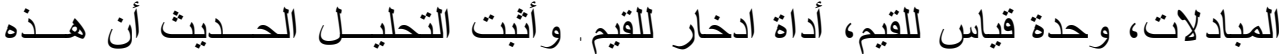




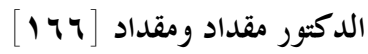

الوظائف تتضح عبر خاصية أساسية للنقد تتمثل في كونه يشكل حـصر أ للـسيولة

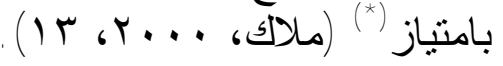

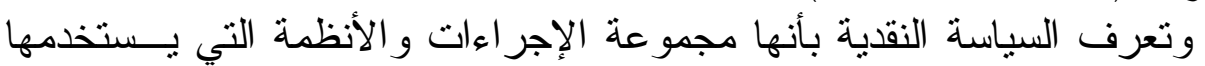

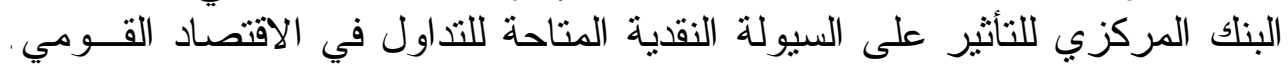

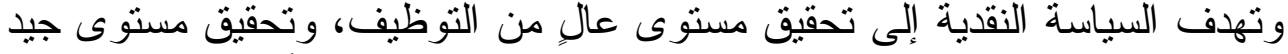

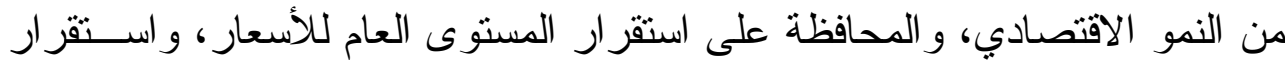

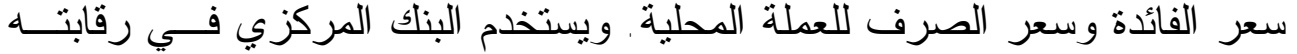

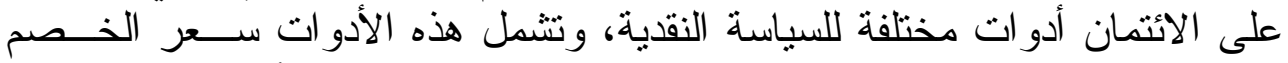

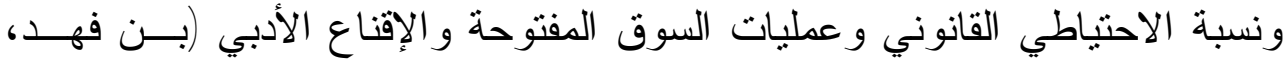
(r)

ثانياً - التطورات النقدية و المصرفية في فلسطين مر النظام النقدي في فلسطين بالعديد من المر احل، فئل فخلال الاتنداب البريطاني

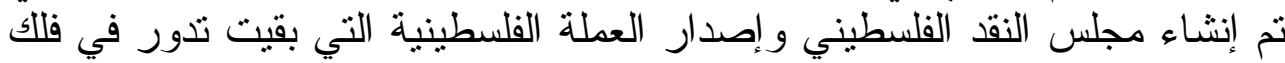

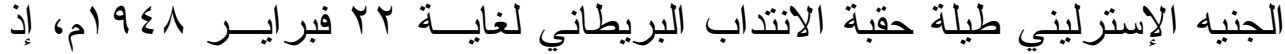

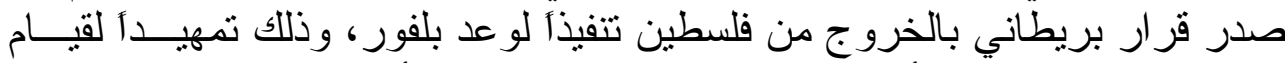

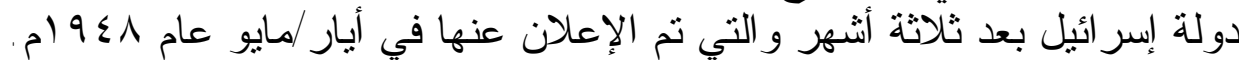

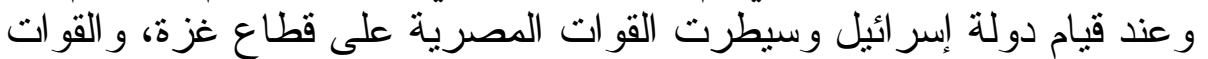

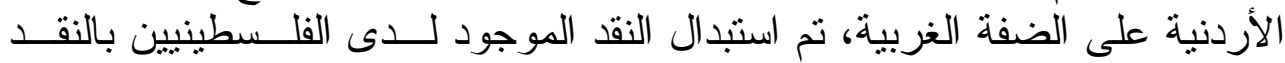

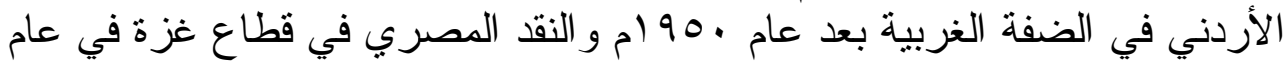

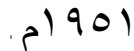

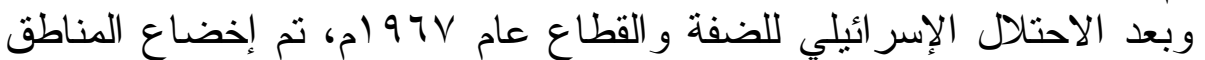

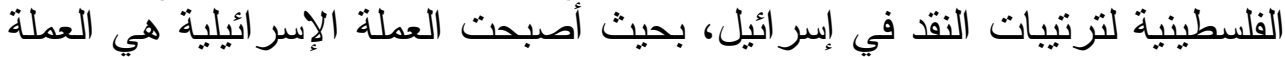
القانونية المعتمدة في تسوية المدفو عات التهات

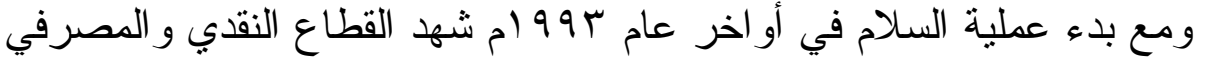

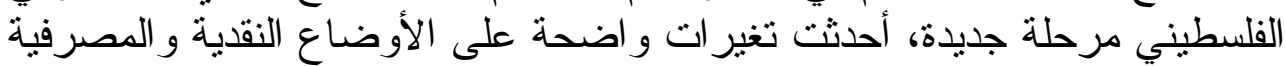

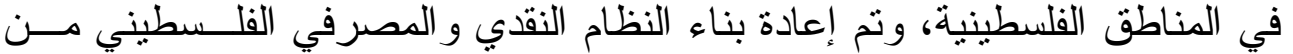

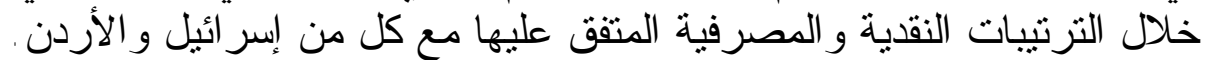

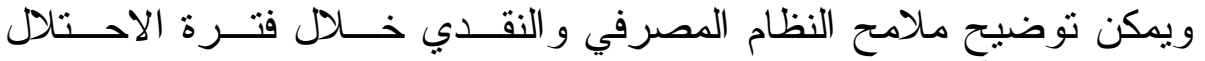

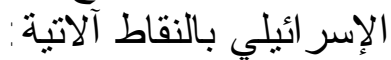

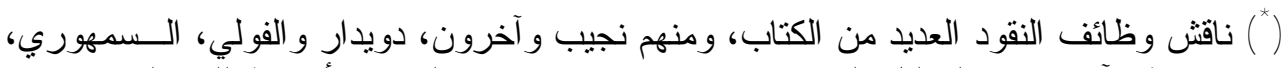

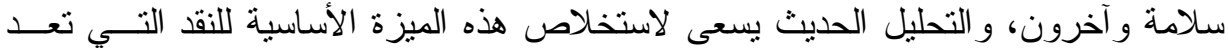

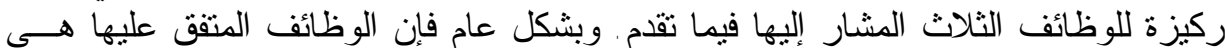
الني تم مناقشتها في هذا السياق. 
1 . غياب سلطة نقدية مركزية يخضع لها النظام النقدي لضمان الاستقرار النقدي

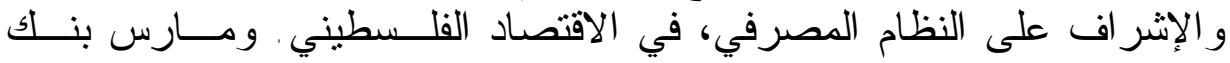

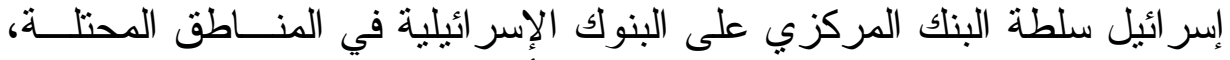

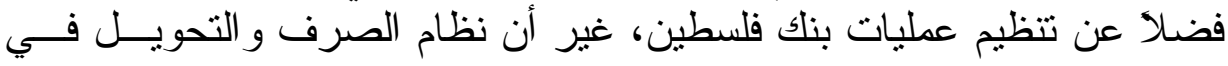

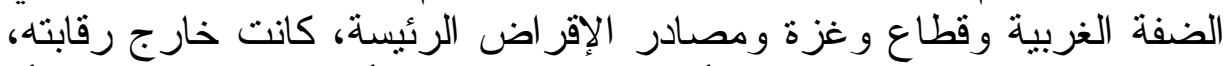

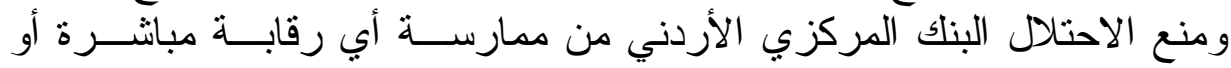

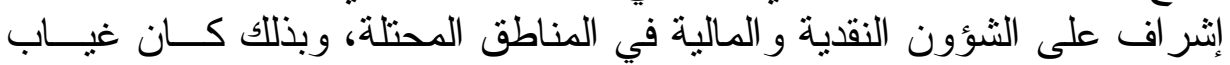

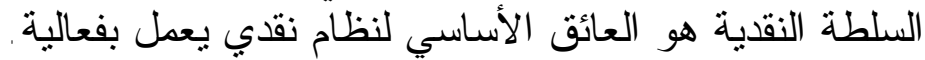

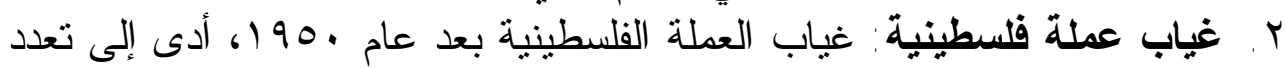

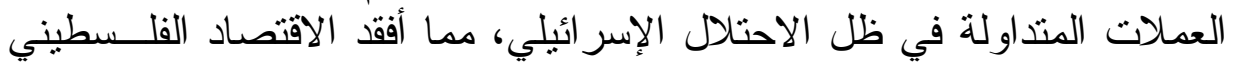

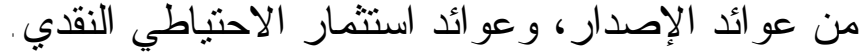

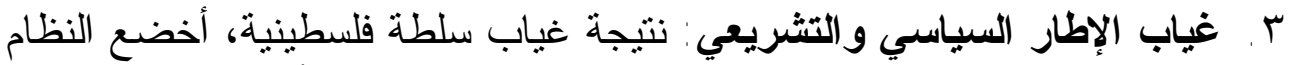

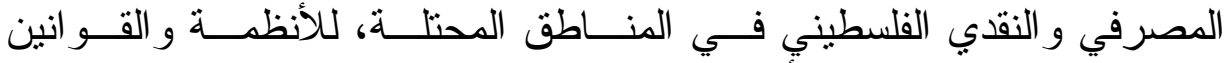

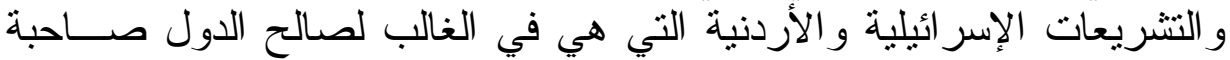

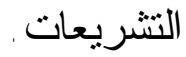

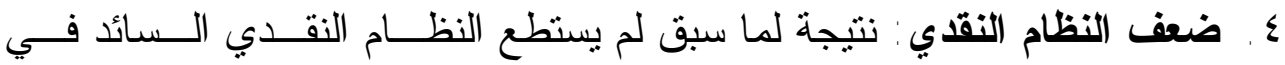

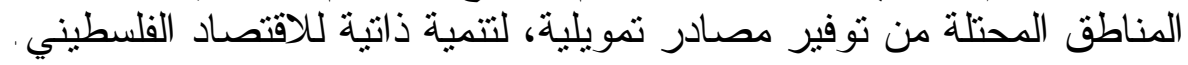

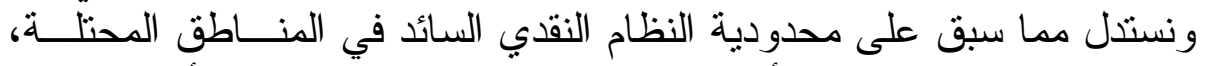

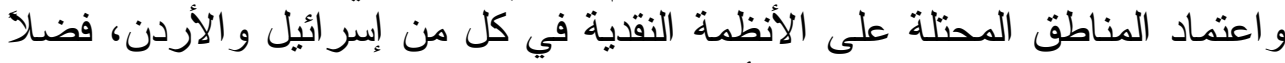

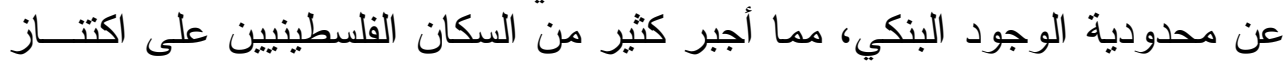

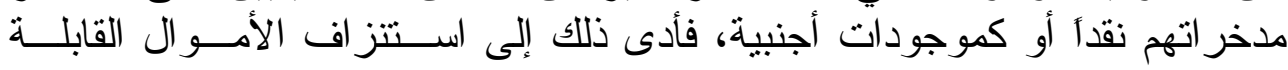
ل اللاستثمار في السوق المحلي.

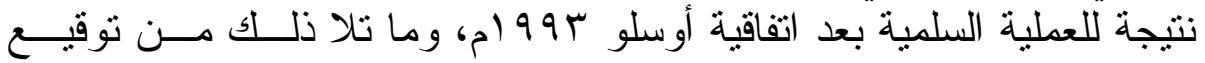

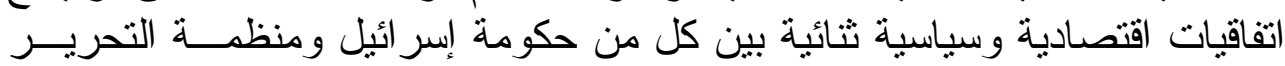

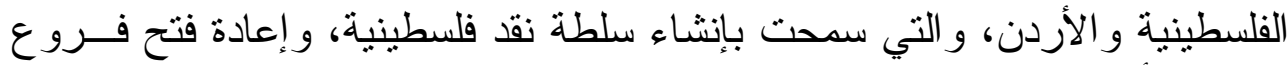

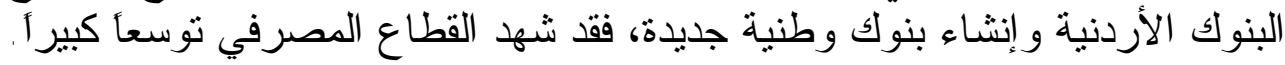

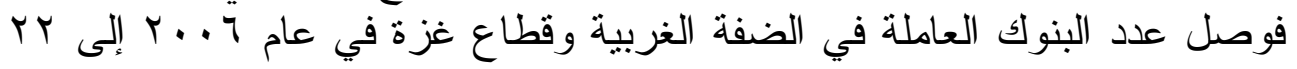

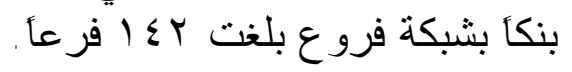

ثالثاً - العملات الأجنبية في الاقتصاد الفلسطيني

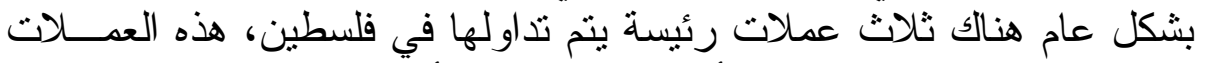

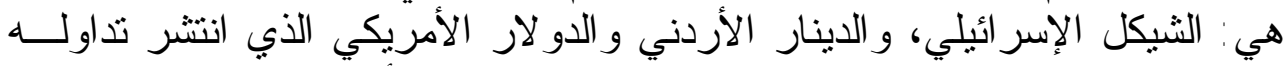

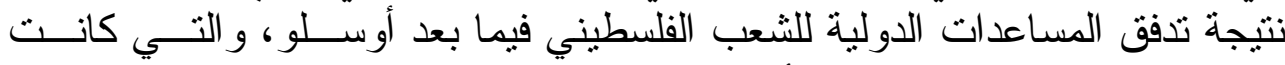
محكومة في معظمها بالدو لار الأمريكي. 


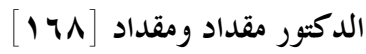

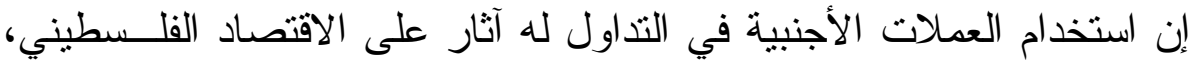

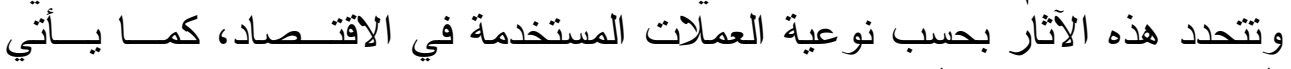

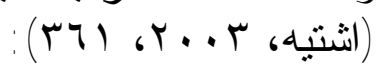

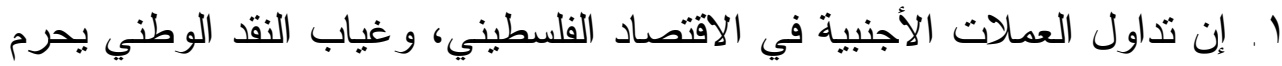

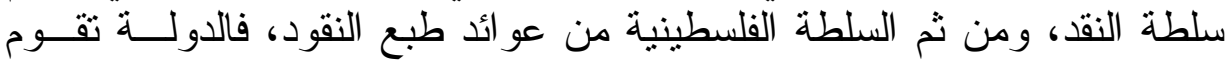

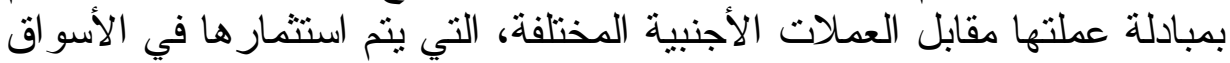

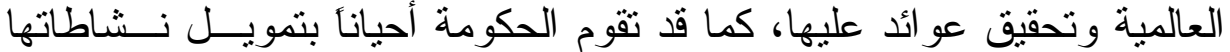

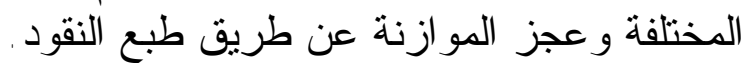

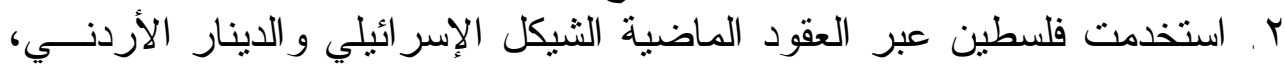

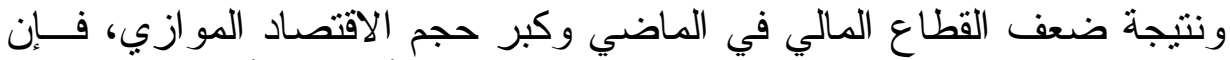

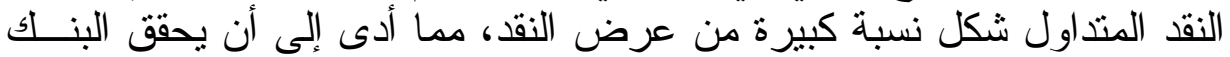

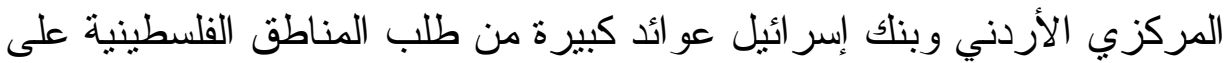

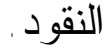

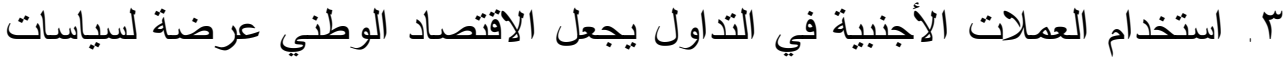

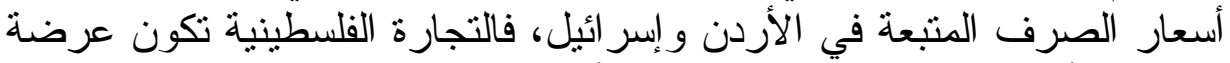

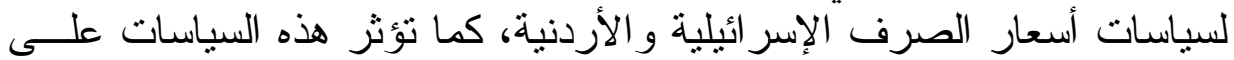

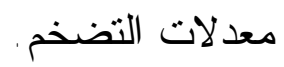

ء . استخدام العملات الأجنبية في التداول في فلسطين أدى إلى تسمية السلع المختلفة

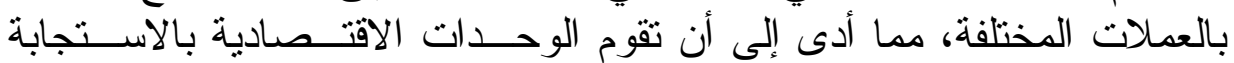

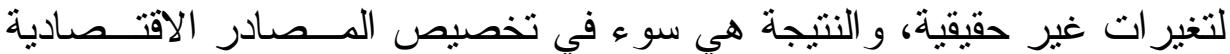

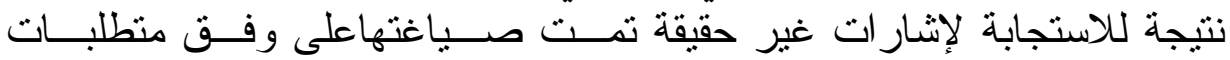

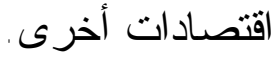

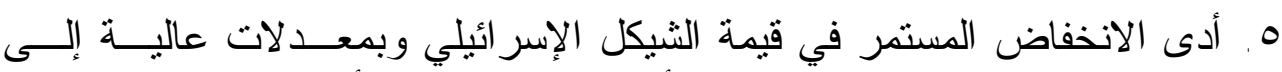

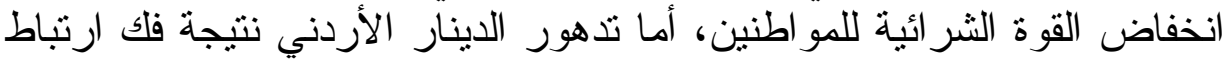

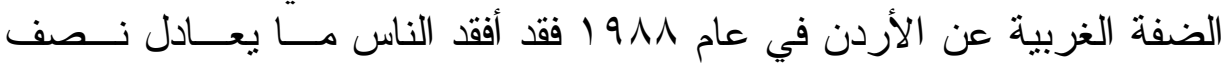

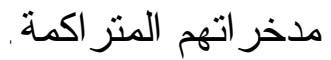
T. إن استخدام عملات مختلفة في التداول في فلسطين، قد يخفق من حدة الآثــار

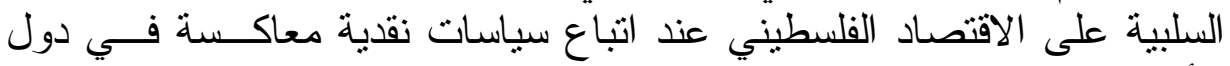

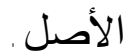

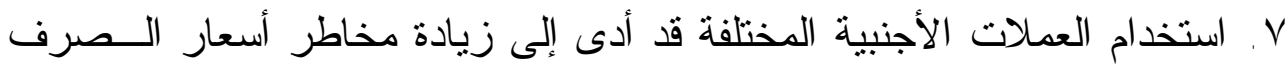

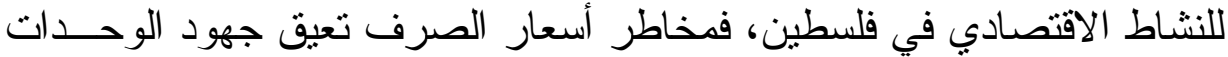

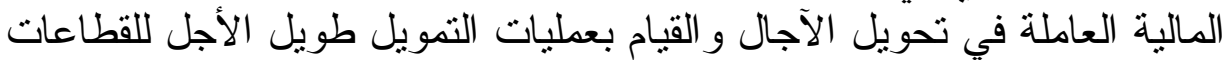

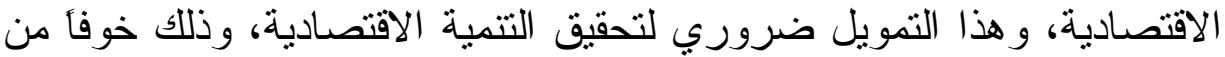

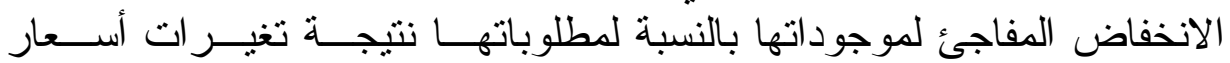

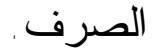


1. استخدام عملات الدول الأخرى ينقل التضخم للاقتصاد الفلسطيني، أو ما يسمى

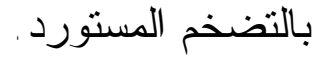

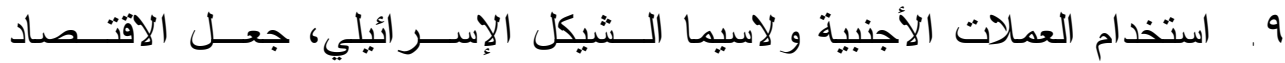

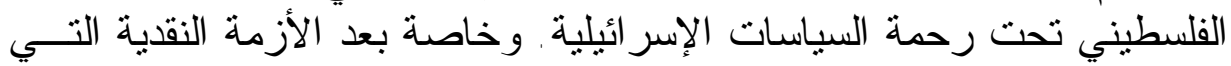

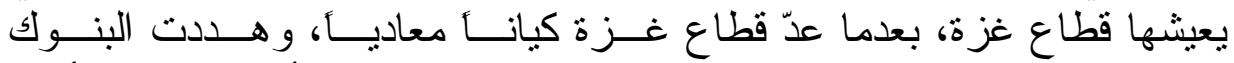

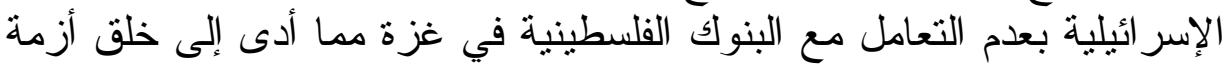
سيولة نقدية في قطاع غزة.

رابعاً - الآثار الناجمة عن غياب العملة الوطنية

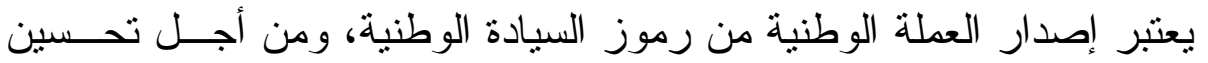

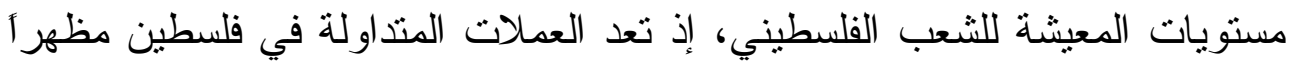

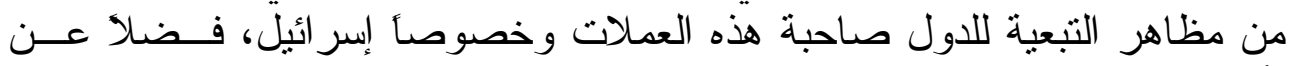

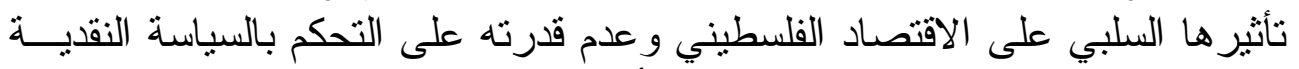

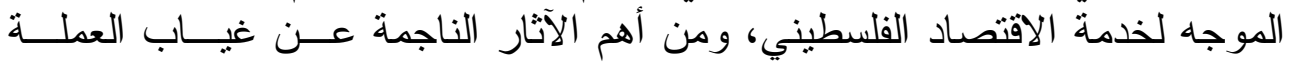

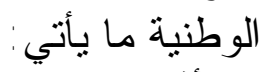

ا ـ أثر غياب ألعملة الوطنية على السياسة النقدية

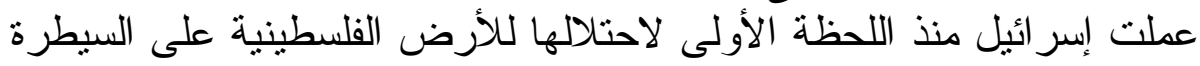

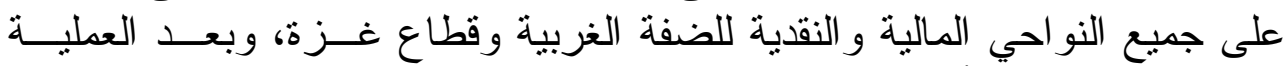

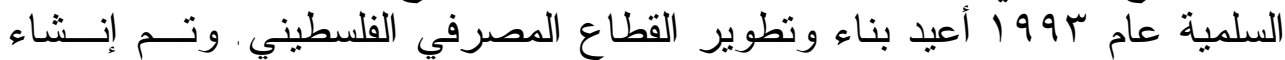

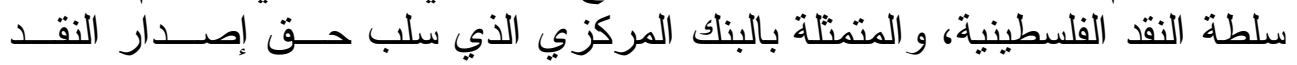

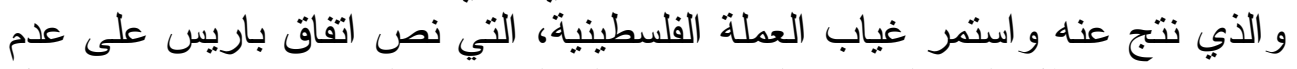

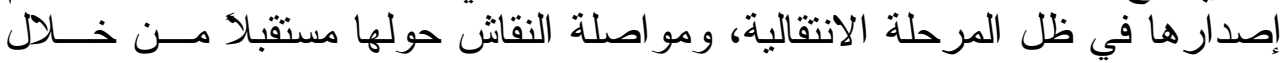
اللجنة الاقتصادية الفلسطينية المشتركة.

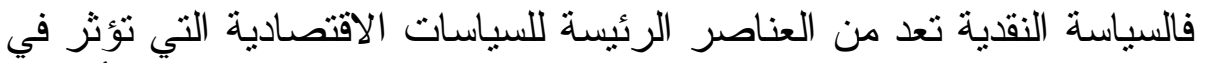

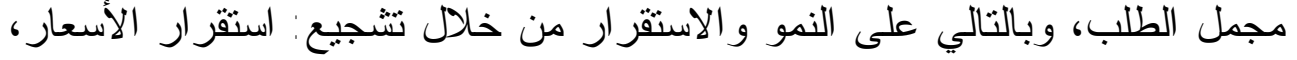

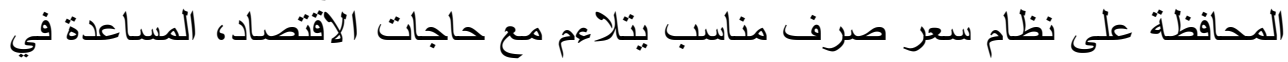

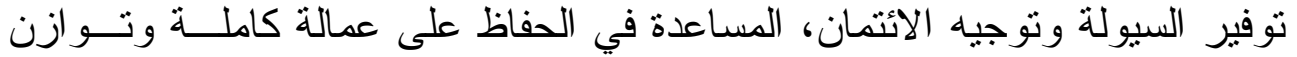

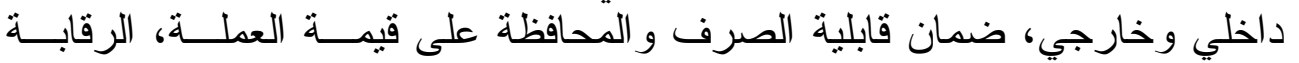

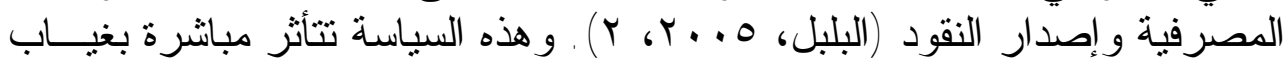

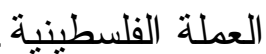

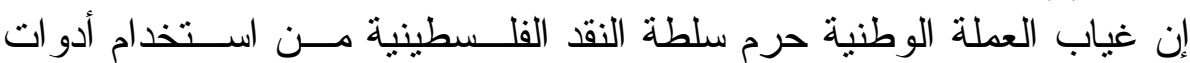

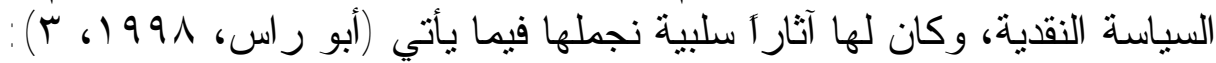

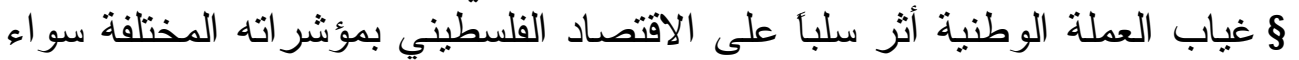

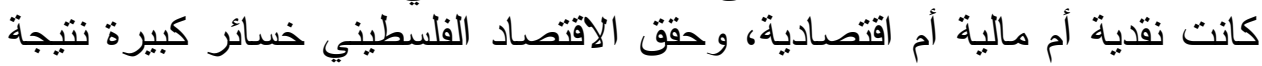


غياب العملة الوطنية واستخدام العملات المختلفة في التذاول و لاســيما الــشيكل

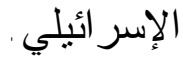

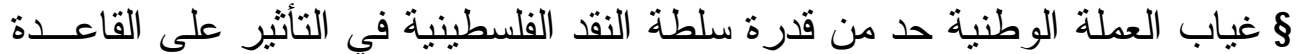

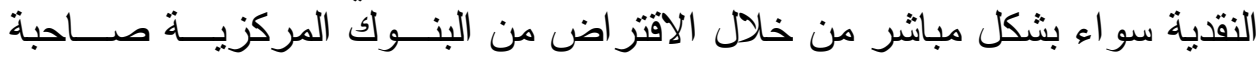

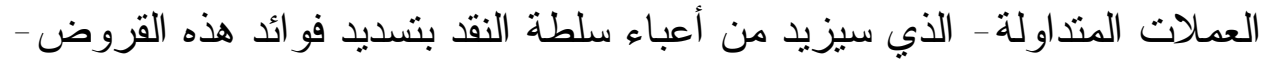

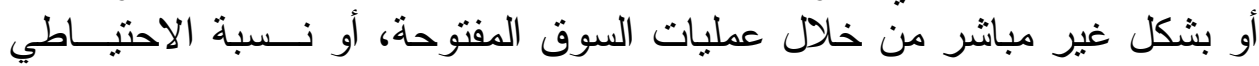
القانوني أو سعر الخصم.

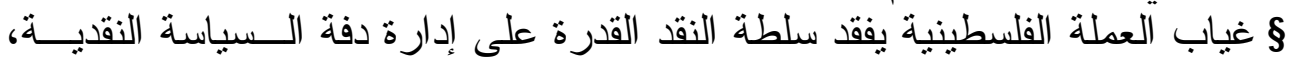
و التي تعتبر من أهم وظائف السلطات النقاية على الإطلاق، بما يحقق المــصالح

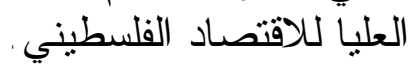
ß غياب النقد الفلسطيني يحرم سلطة النقد الفلسطينية من استخدام أدوات الـسياسة

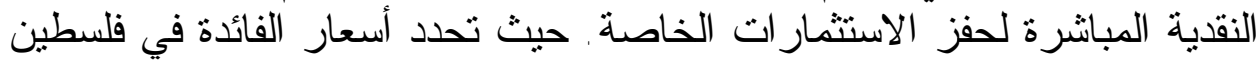

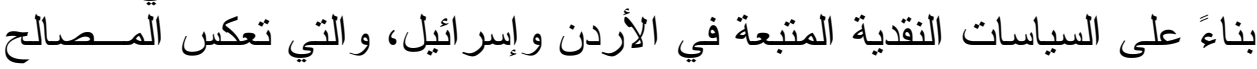

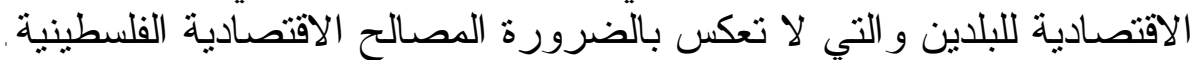

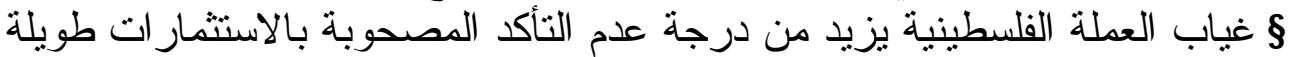

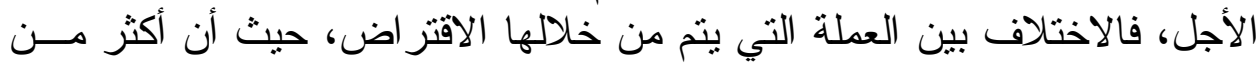

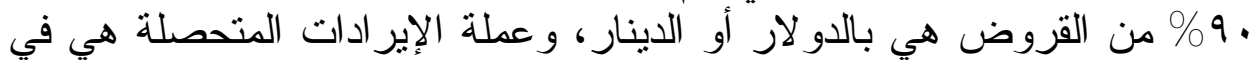

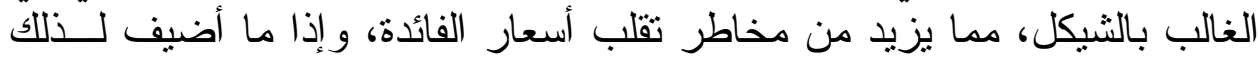
مخاطر تغير السياسات النقدية في الأردن و إسر ائيل وتأثير ذلك على على هيكل الفو ائد

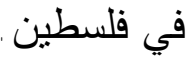

إذأ لا يقتصر أثز غياب العملة الوطنية على غياب السياسة النقدية الفلسطينية

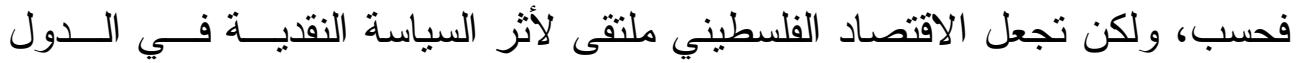

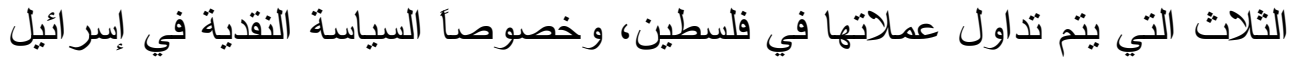

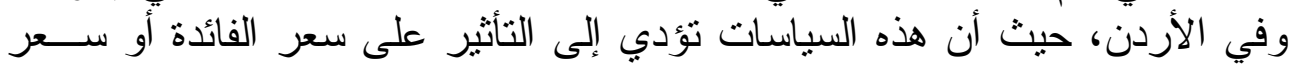

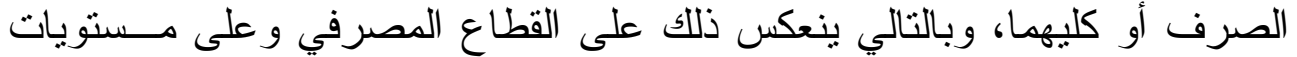

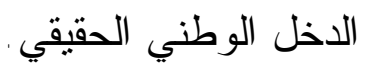

r ـ التكاليف المرتبطة بانخفاض أسعار صرف العملات المتاولة في فلسطين

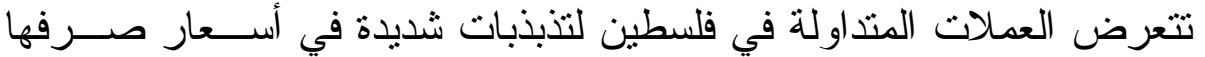

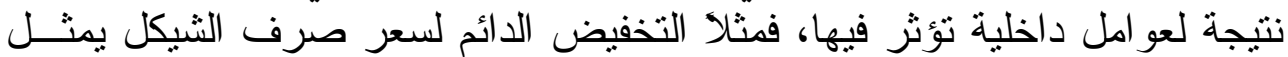

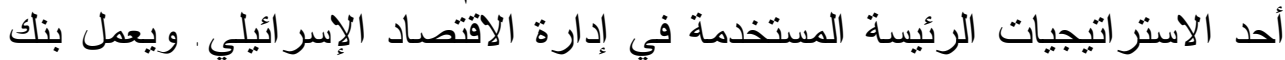

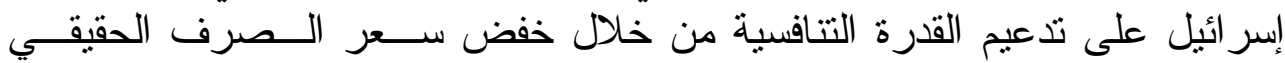

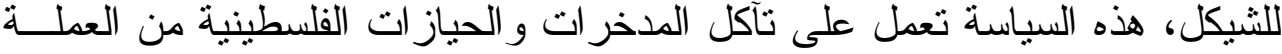

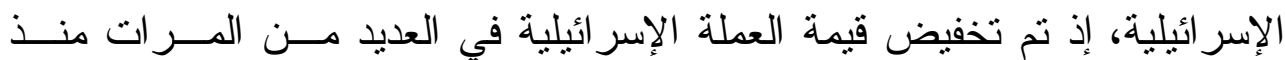

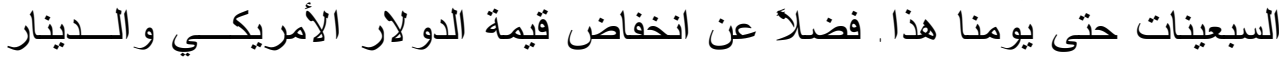

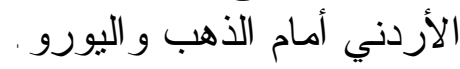


و لانخفاض أسعار صرف العملات المتداولة تأثثير ات كبيرة علــى الاقتـ صـاد

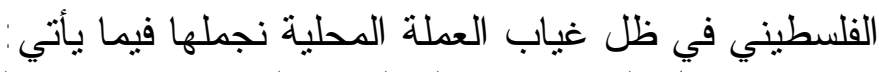

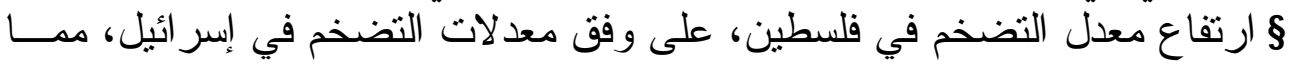

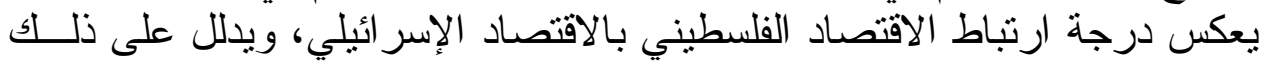

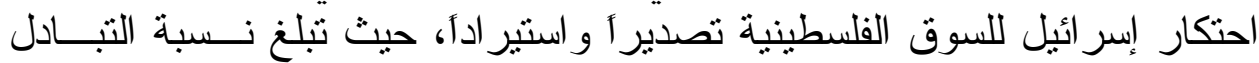

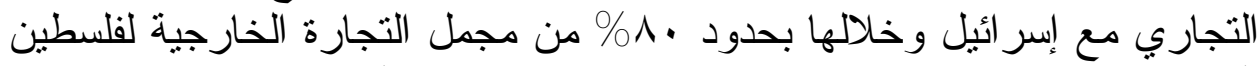

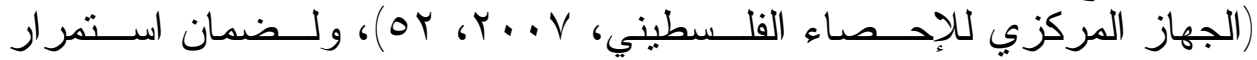

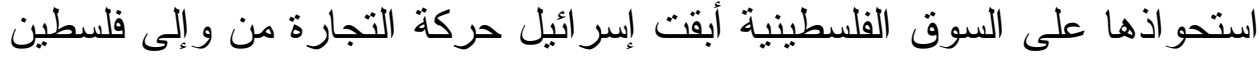

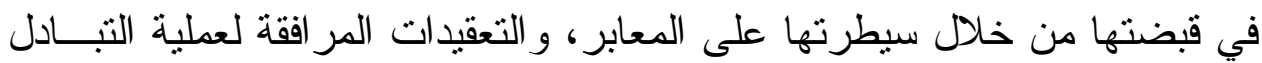
التجاري بين فلسطين وبقية العالم الخارجي.

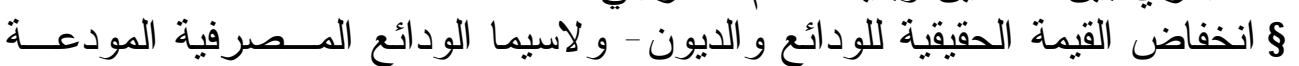

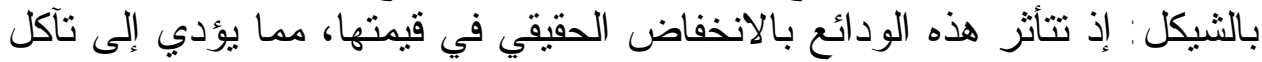

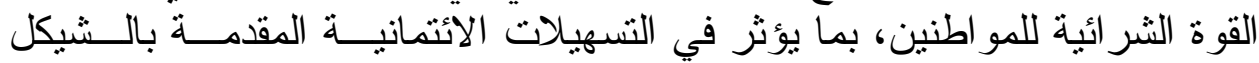

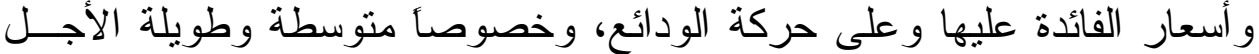

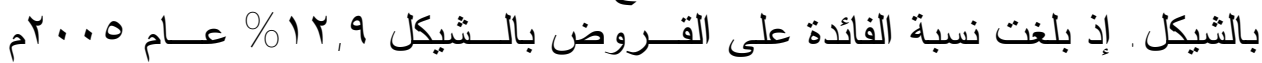

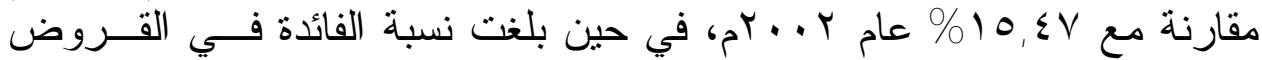

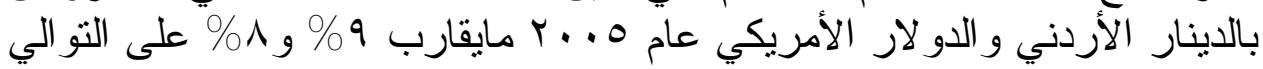

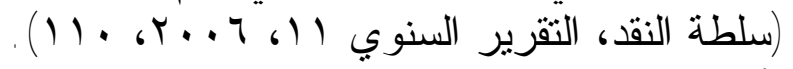

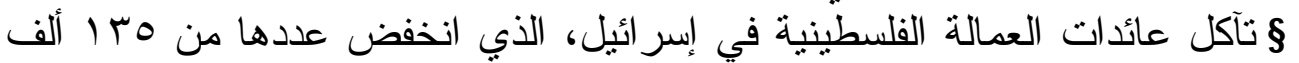

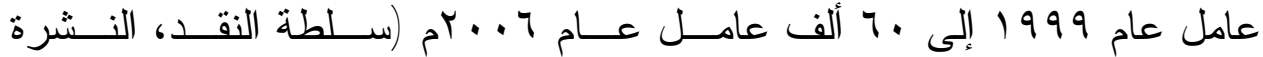

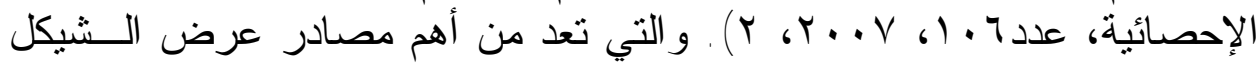

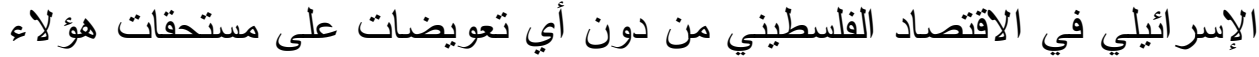

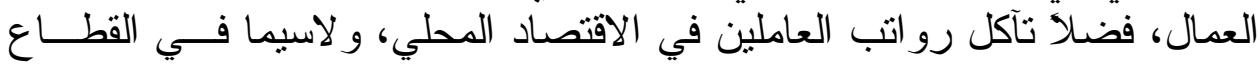

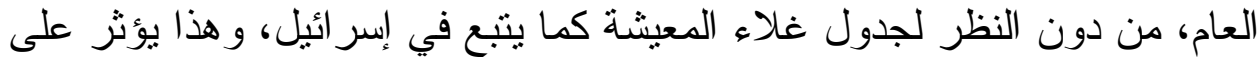

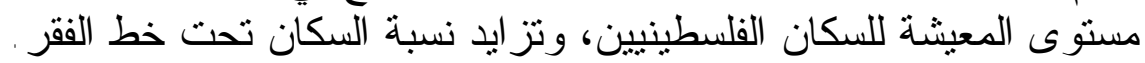

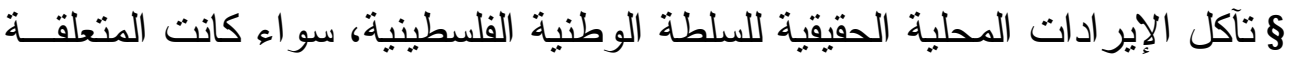

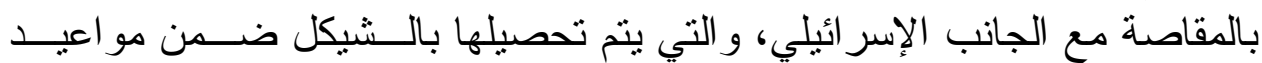

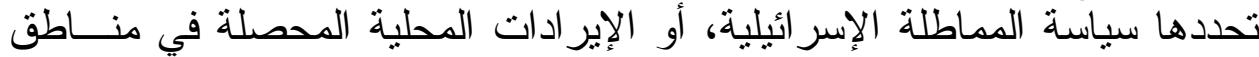

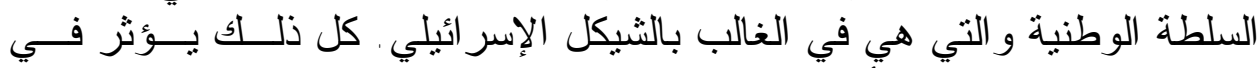

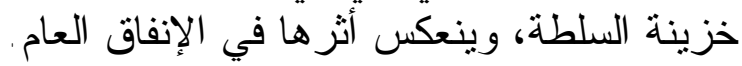

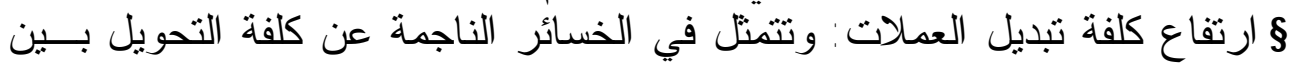

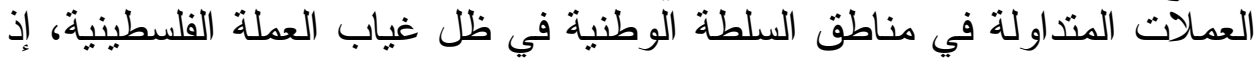

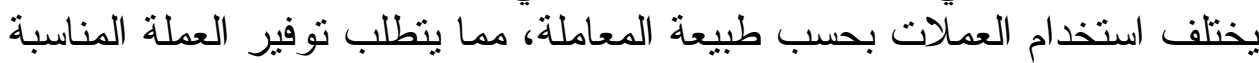

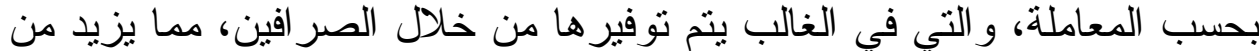

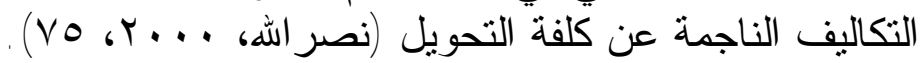




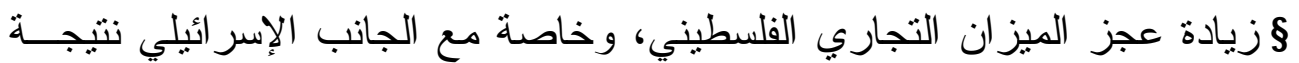

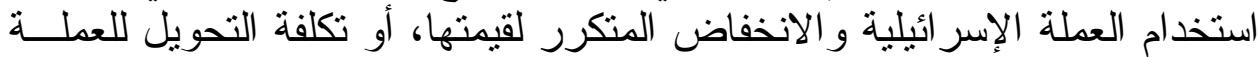

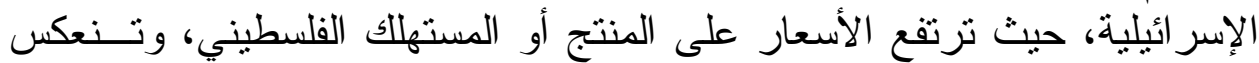

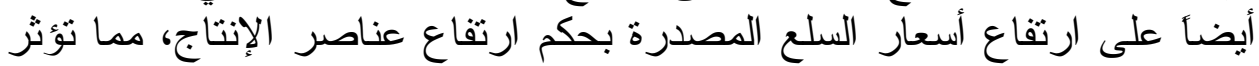

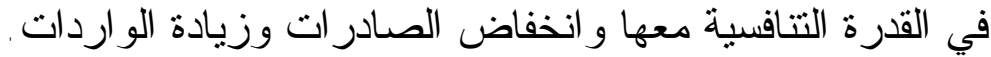

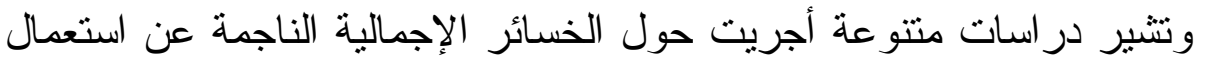

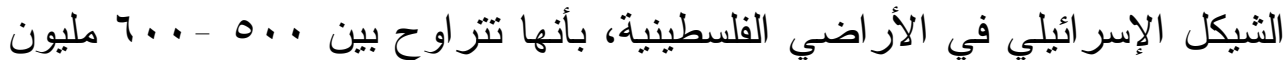

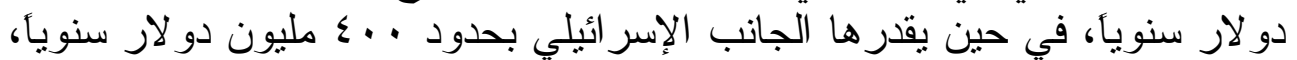

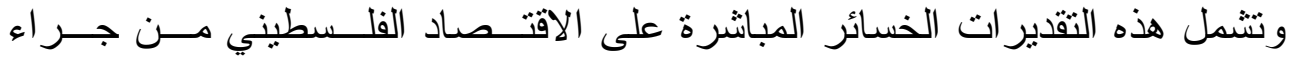

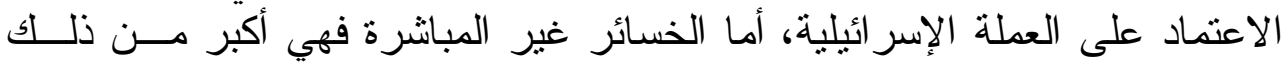

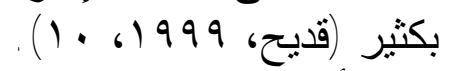

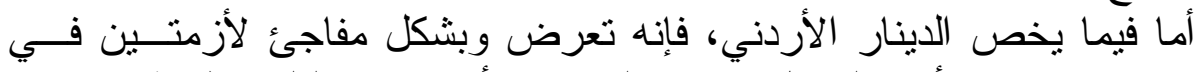

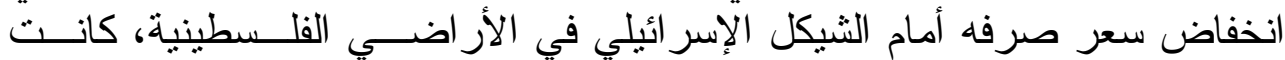

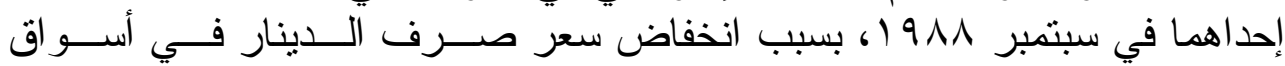

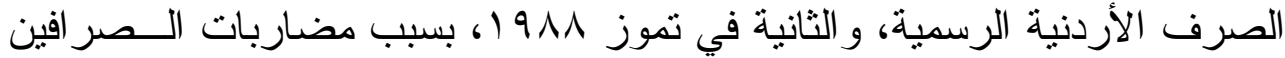

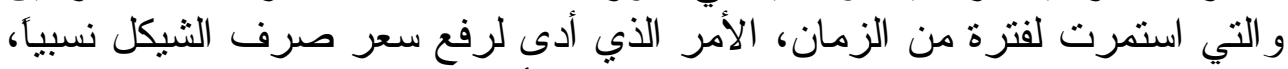

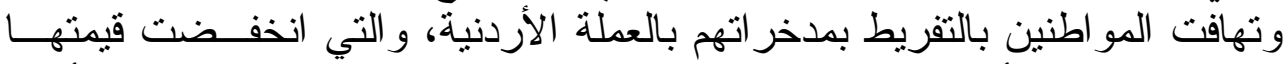

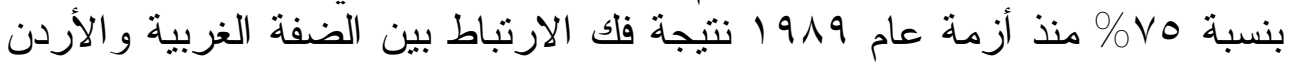

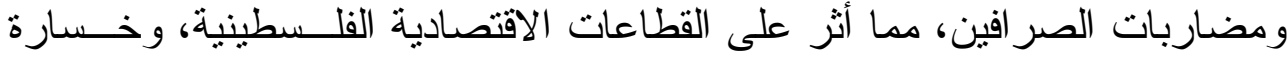

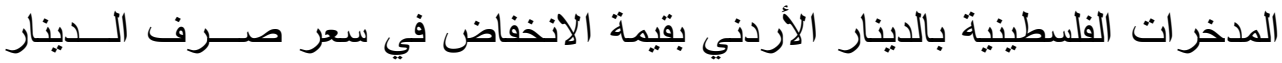

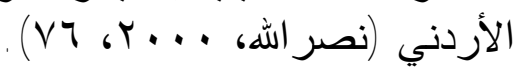

\section{r. مشاكل تطبيق موازنة السلطة الوطنية القلسطينية}

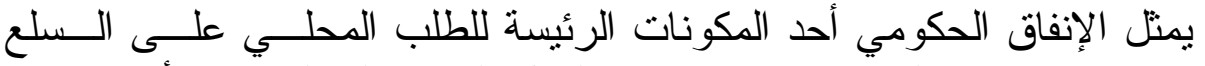

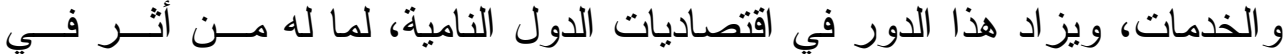

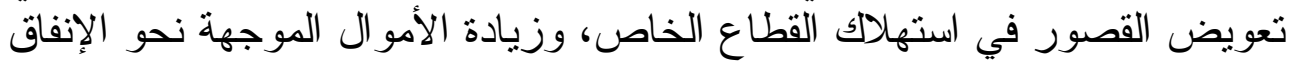

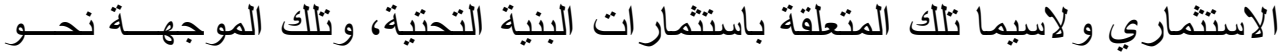

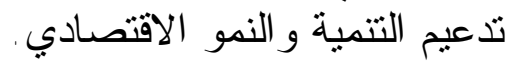

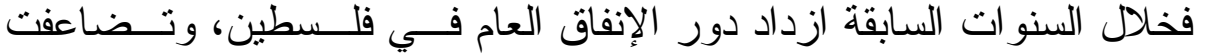

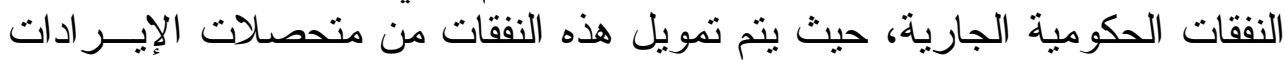

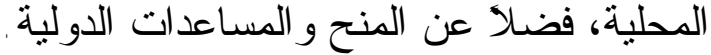

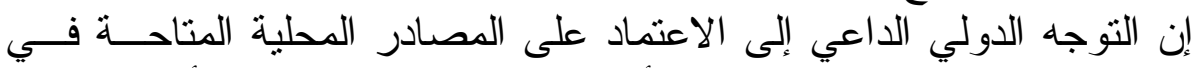

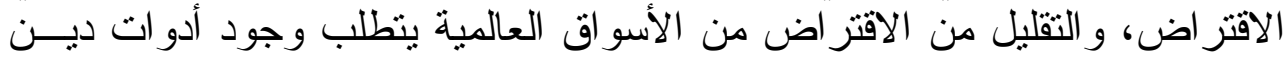

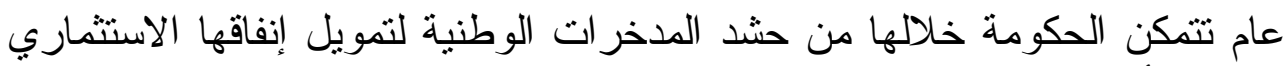

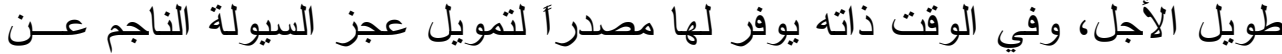

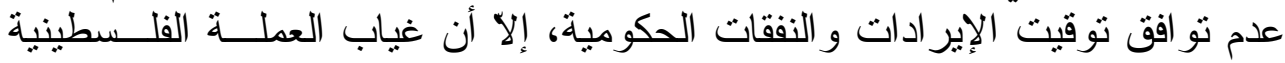




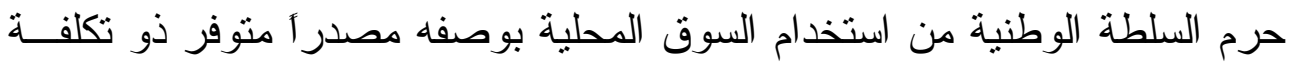

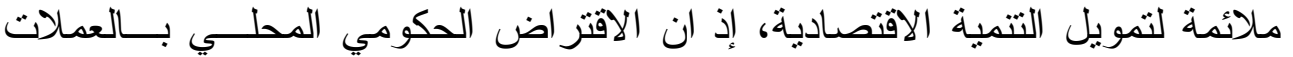

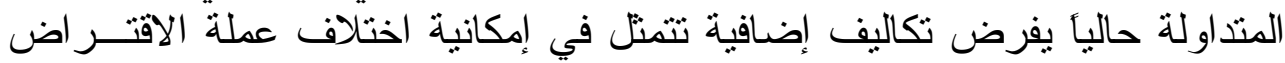

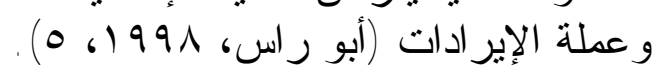

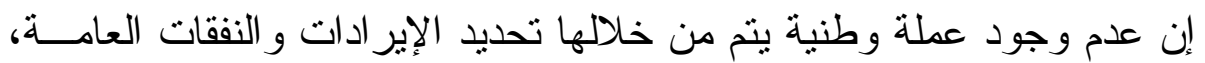

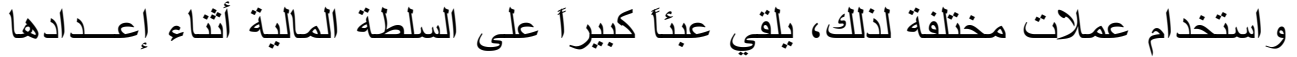

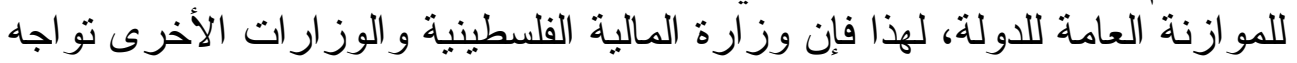

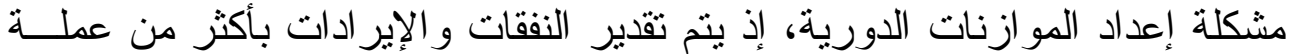

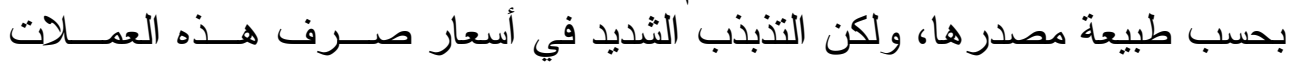

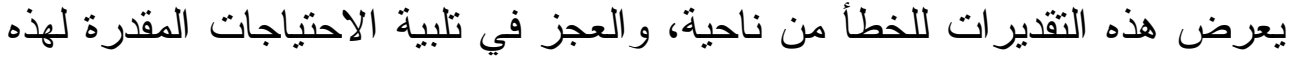

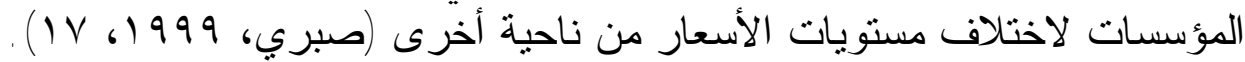

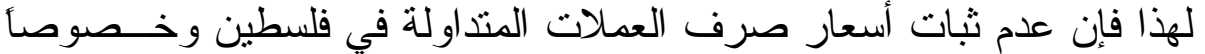

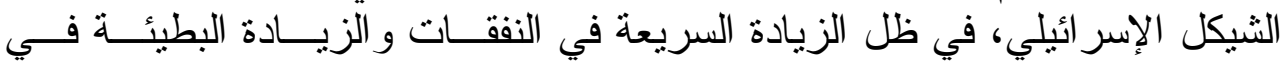

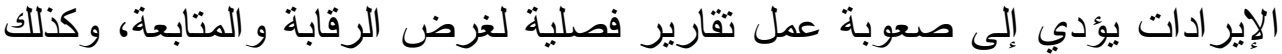

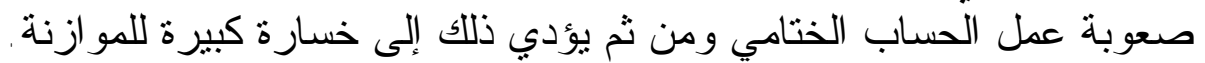

ع ـ ضعف القدرة على ضبط إدارة العلاقات الاقتصادية الخارجية

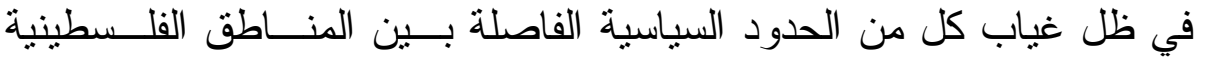

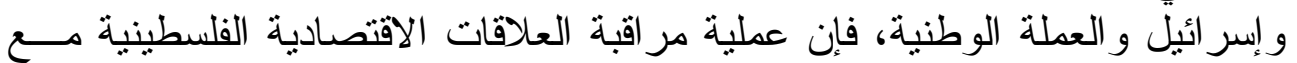

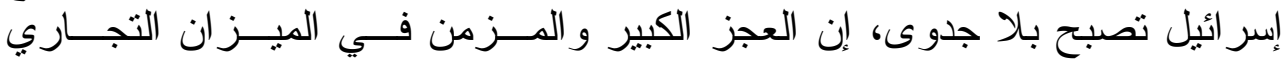

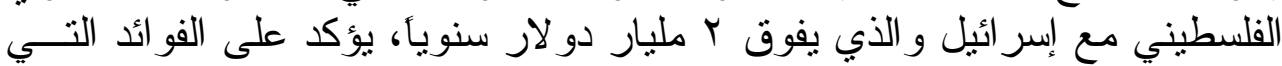

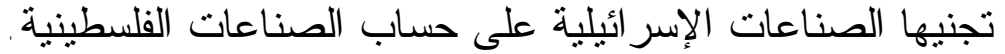

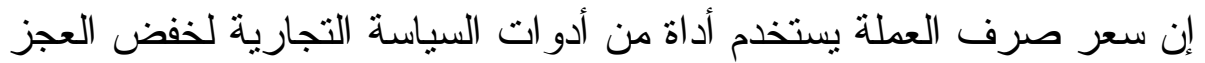

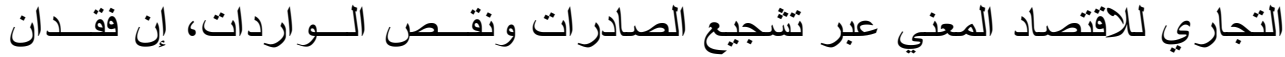

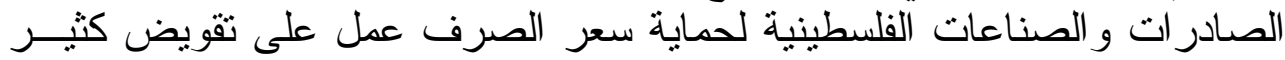

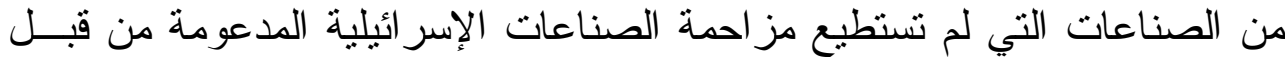

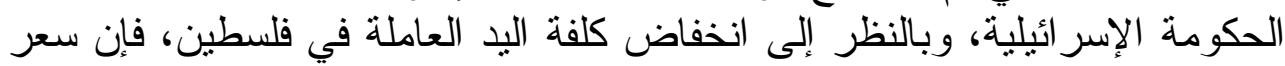

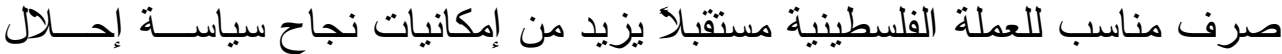

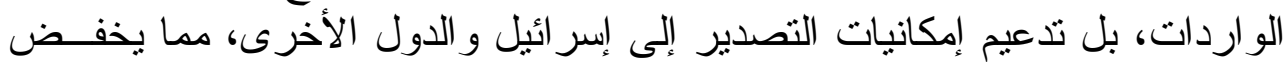

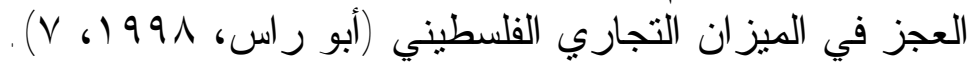




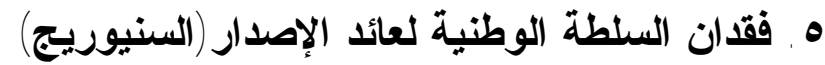

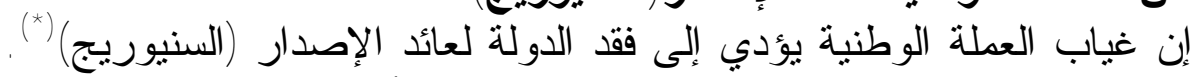

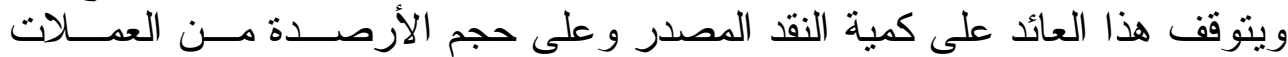

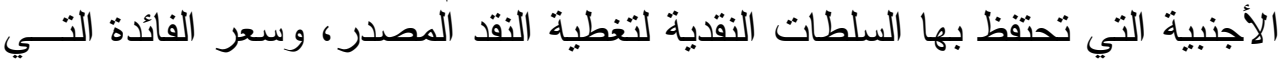

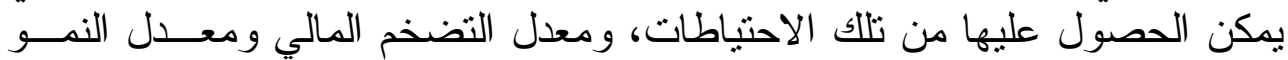
الاقتصادي (World Bank, 1993, 62)

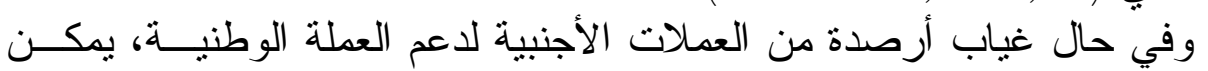

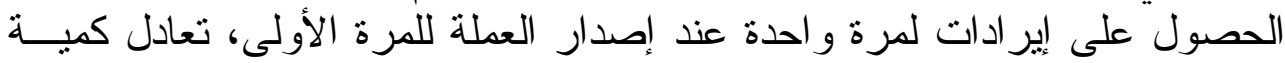

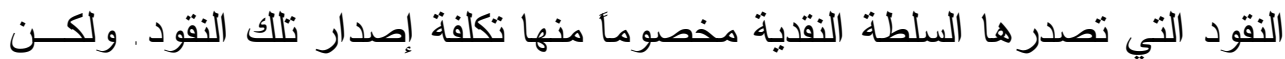

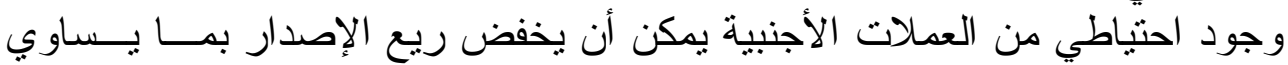

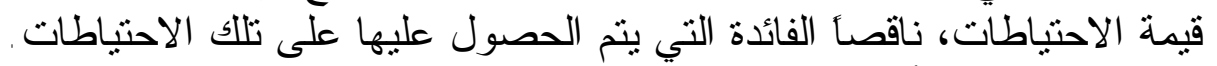

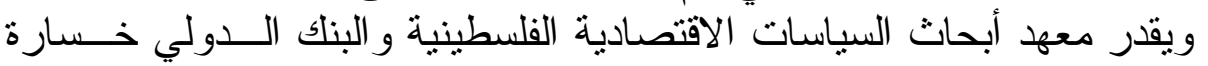

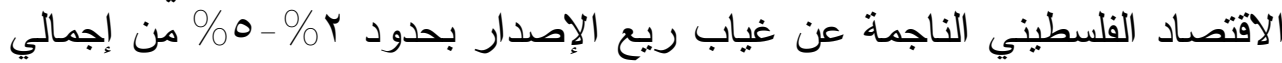

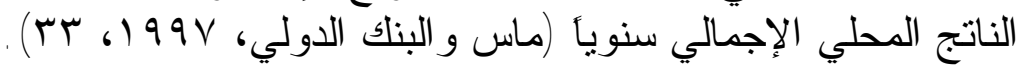

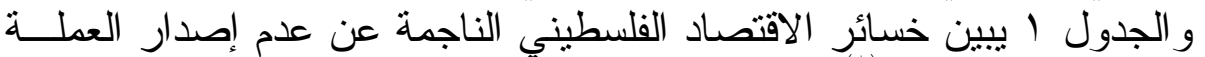

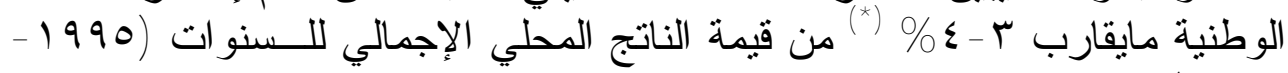

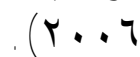
من الجدير بالذكر أن الدول التي يتم تداول عملاتها في فلسطين هـي التـي

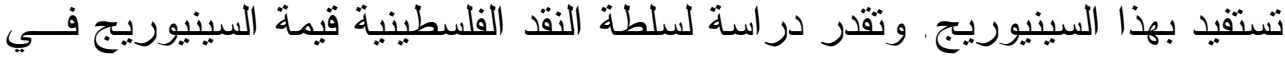
حال إصدار العملة الوطنية بحدود مليار دو لار لمدة خمس سنوات النهات (التقرير النهائي

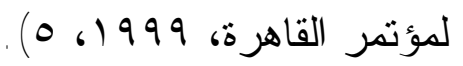

\begin{tabular}{|c|c|c|c|}
\hline \multicolumn{4}{|c|}{ 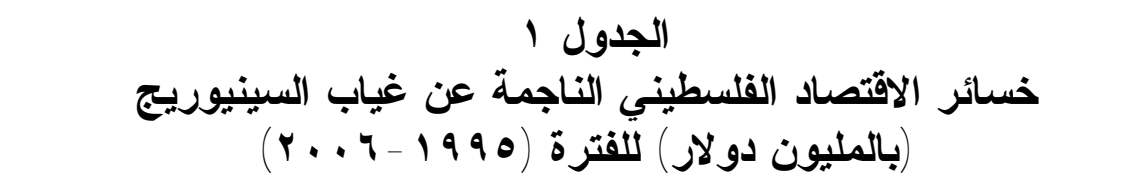 } \\
\hline ؛ \% \% & GDP 3\% من & ${ }^{(* *)}$ GDP & العام \\
\hline$I r V, V T$ & $90, \Lambda$. & $r / 9 r, r$ & 1990 \\
\hline $1 \pi 1, \varepsilon \varepsilon$ & 91,01 & $r Y \wedge 0,9$ & 1997 \\
\hline $1 \leqslant \Lambda, \cdot V$ & $111, .0$ & $r v \cdot 1,7$ & 1991 \\
\hline
\end{tabular}

(") يمثل السنيوريج الريع الذي يمكن للاولة الحصول عليه من جراء الإصدار، وهو العائد على بلى الأصول المغطاة بالعملة المصدرة.

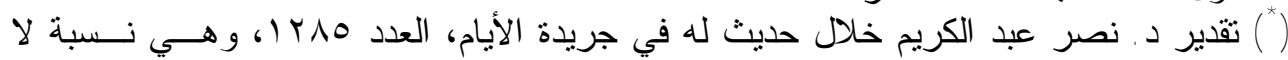

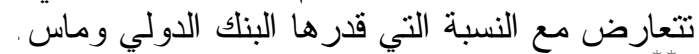

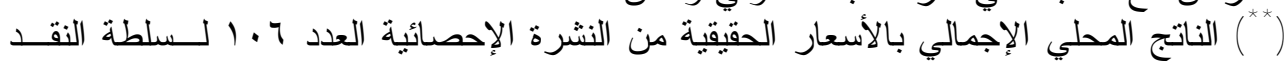




\begin{tabular}{|c|c|c|c|}
\hline ؛ \% من GDP & GDP 3\% من & $T^{* * 1}$ GDP & العام \\
\hline 170,94 & $T K \varepsilon, \varepsilon \varepsilon$ & $\varepsilon 1 \leqslant \vee, q$ & 1991 \\
\hline $1 \wedge \cdot, \varepsilon V$ & $1 \% 0, r_{0}$ & $\varepsilon 011, V$ & 1999 \\
\hline$T V_{\cdot}, \varepsilon \varepsilon$ & $T r V, A T$ & $\varepsilon Y 71,1$ & $r \ldots$ \\
\hline 107,11 & TIV,OT & $r q \mid v, \Lambda$ & $r \ldots l$ \\
\hline $1 \leqslant Y, Y T$ & $1.7, V$. & $r 007, \varepsilon$ & T.. \\
\hline $109,1$. & 119,10 & $r 990$ & $r \ldots r$ \\
\hline 179,91 & $T r V, \varepsilon r$ & $\varepsilon r \leqslant V, V$ & $r \ldots \varepsilon$ \\
\hline$|V V, V|$ & TrT,YA & $\varepsilon \varepsilon \varepsilon r, V$ & $r \ldots 0$ \\
\hline $177, \cdot 4$ & $T Y \varepsilon, O r$ & $\sum 10 \cdot, 7$ & $r \ldots T$ \\
\hline $1 \wedge 97, \varepsilon \wedge$ & $1 \leqslant Y Y, r Y$ & - & المجموع \\
\hline
\end{tabular}

- - جمع البيانات الو اردة في الجدول و استخر اج النسب من إعداد الباحثين .

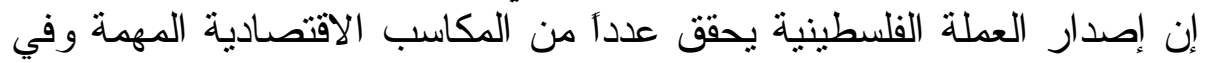

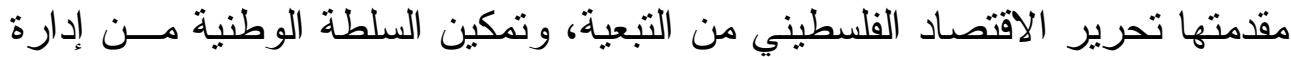

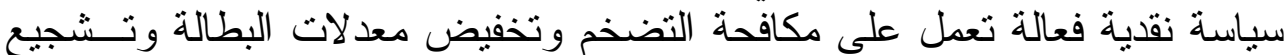

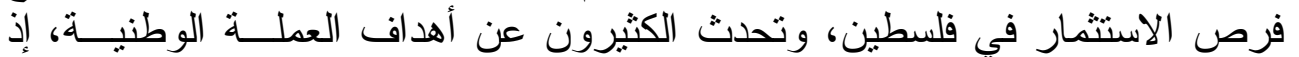

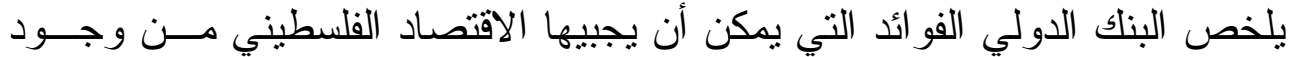

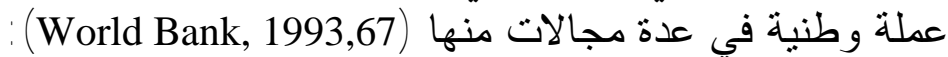

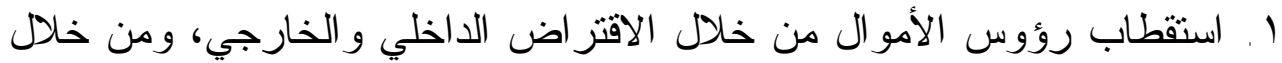
ريع الإصدار (و الذي سوف الأبول يكون محدود في الإن البداية) . r ب إدارة التذفقات الر أسمالية.

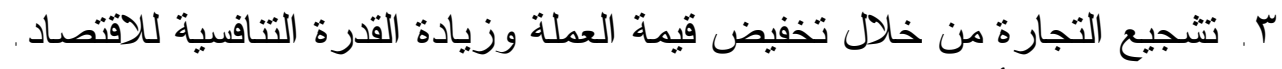

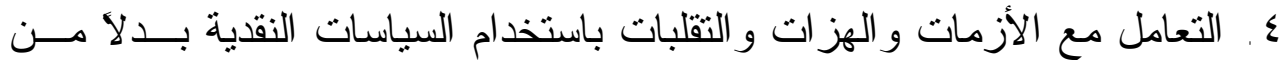
الاعتماد على السياسة المالية فقط.

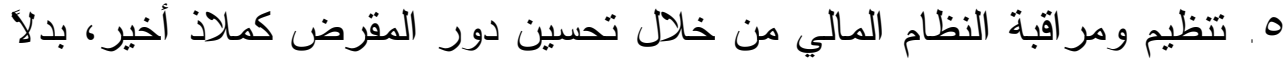

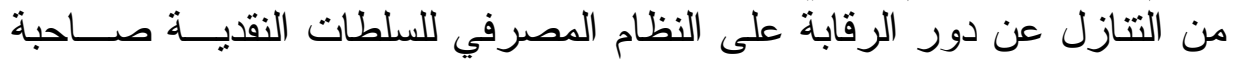

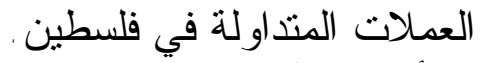

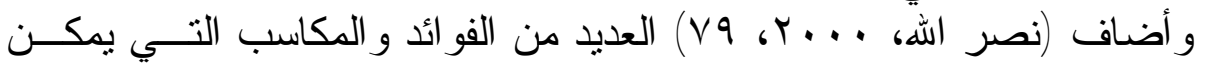
تحقيقها عند إصدار العملة الوطنية منها:

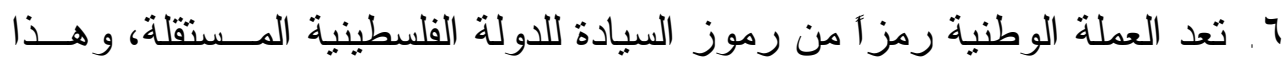

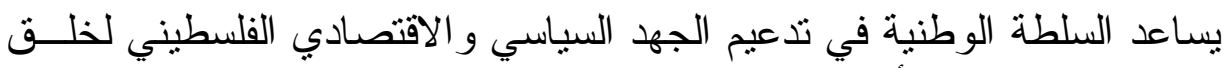
وقائع سيادية على الأر اضي الفلسطينية. 
الدكتور مقداد ومقداد [IVV]

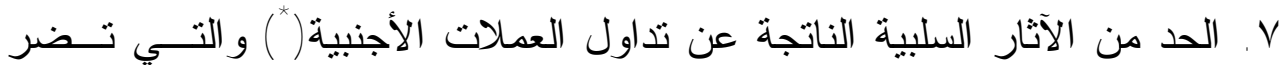

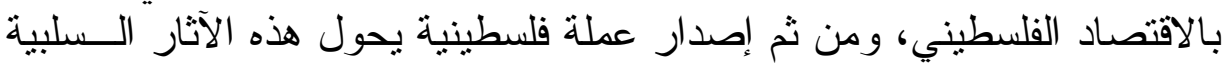

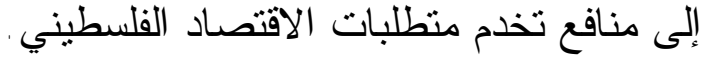

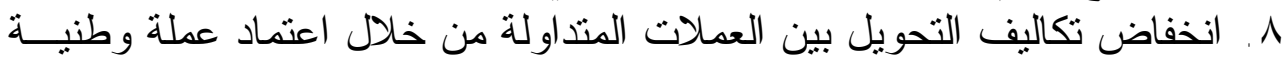
تتداول بشكل قانوني في غالبية المعاملات . 9 ـ انخفاض معدلات التضخم (التضخم المستورد) الناتجة عن استخدام العمــلات الأخرى.

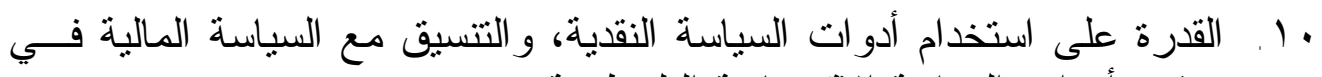
تحقيق أهداف السياسة الاقتصادية الفلسطينية.

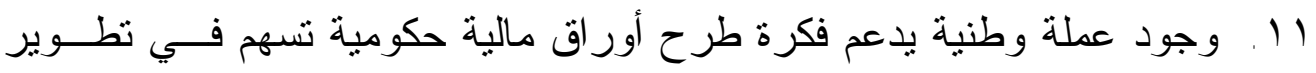
الاقتصاد .

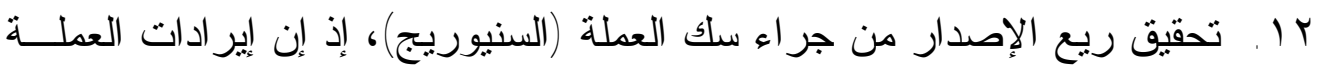

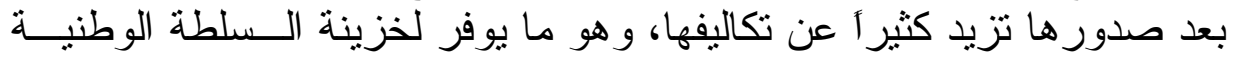
إير ادات مهمة س ا . الحرية في ضبط أسعار الصرف بحسب السياسة العامة التي تضمن الاستقرار

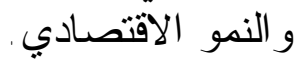

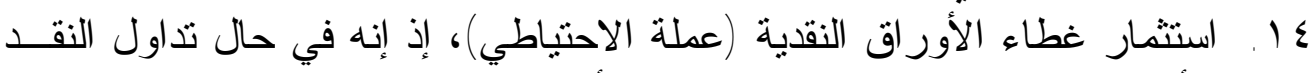

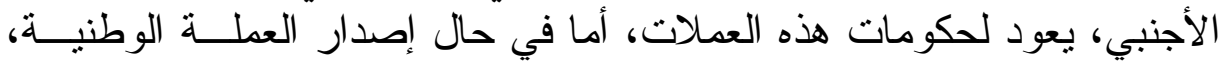

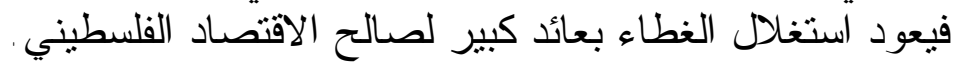

سادساً - محاذير ومعوقات إصدار العملة القلسطينية ومن أهم المحاذير و المخاوف التي يمكن ذكرهات إهـا حول عملية إصدار العملـــة الفلسطينية ما بأني : اهن I ـ الخوف من وقوع السلطة الوطنية في فخ الإغر اء المتمنل في طبع المزيد مــن فئن

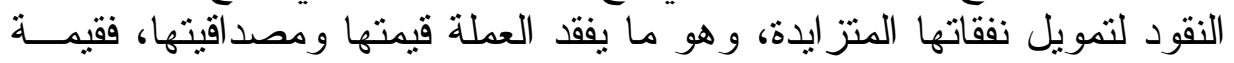

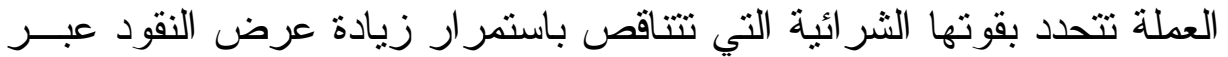

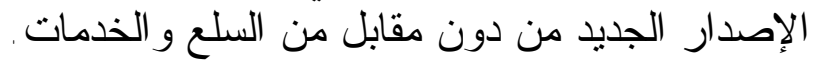

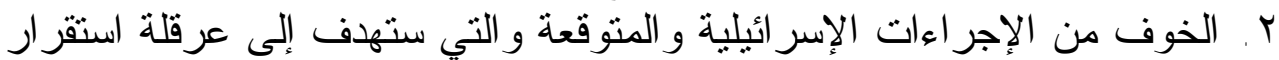

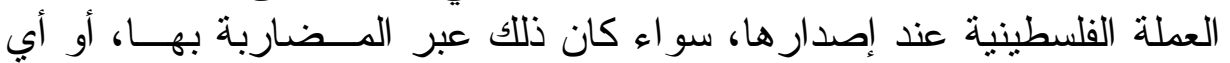
إجر اءات أخرى على المستوى النقدي أو الاقتصادي (لبد، 0 . . ب، 0 (1) ).

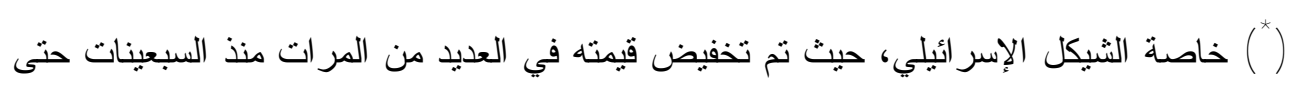

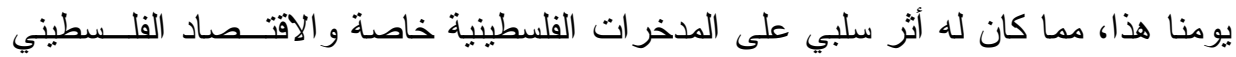


r. الخشية من ضعف الثقة المحلية بالعملة المصدرة من قبل الجمهور ومــن ثـم

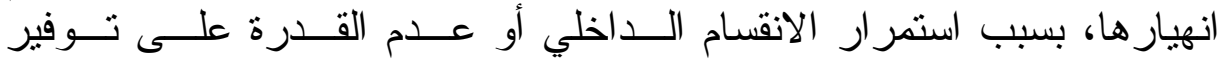
الاحتياطات النقدية اللازمة بوصفها الانيا غطاءً للتعملة الفلسطينية.

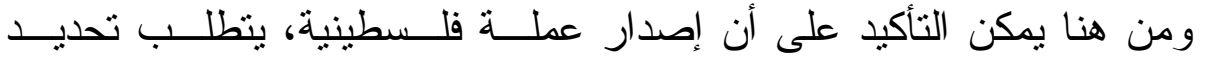

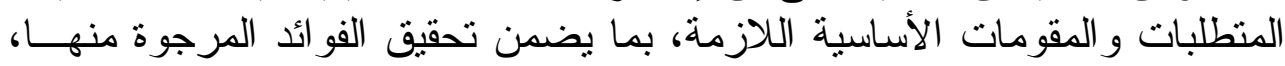

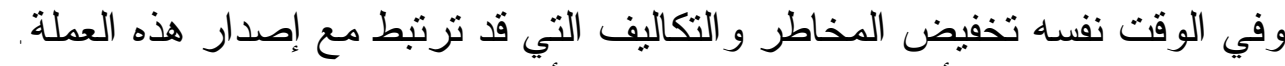

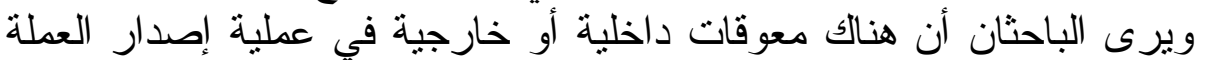

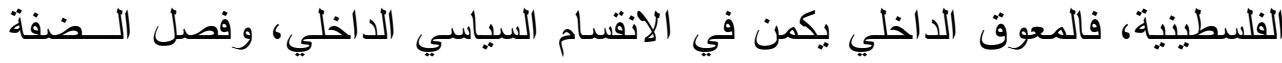

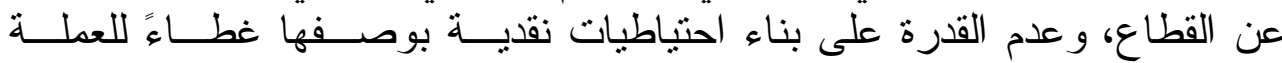

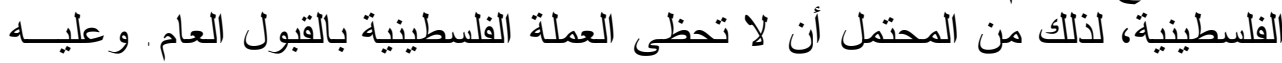

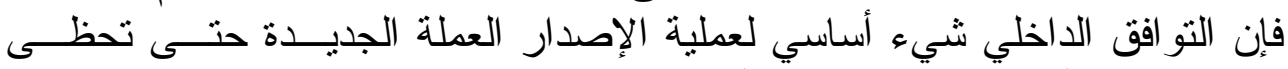

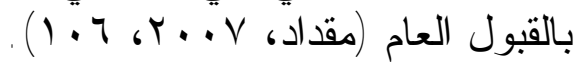

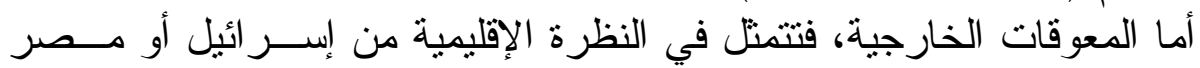

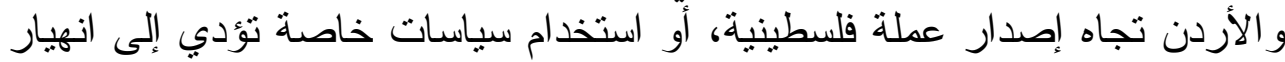

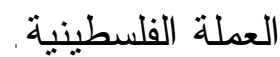

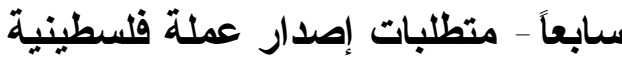

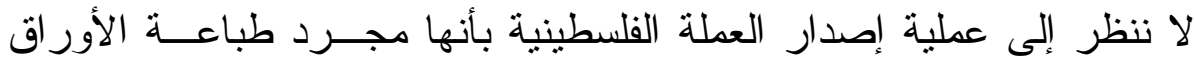

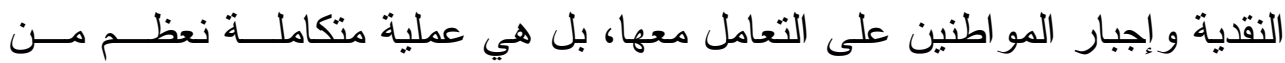

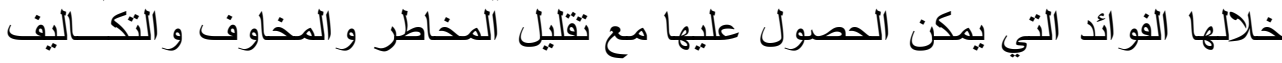
المرتبطة بهذه العملية.

لذللك فمن الضروري توفر المقومات الأساسية المبنية على أسـس سياســية

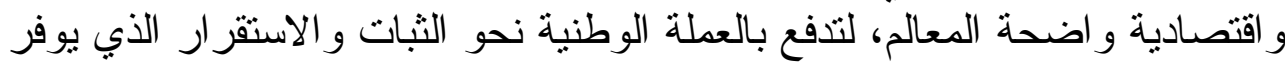

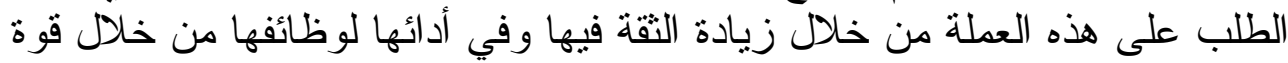
الاقتصاد و أدائه الجيد.

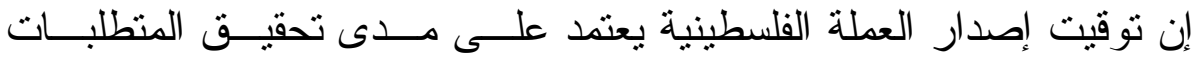

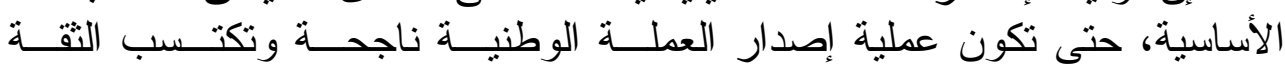
و المصداقية. ويناقش الباحثان مجموعة من المنطلبات المهمة لإصدار العملة على لـى

\section{أ. وجود القتصاد قوي وفعال}

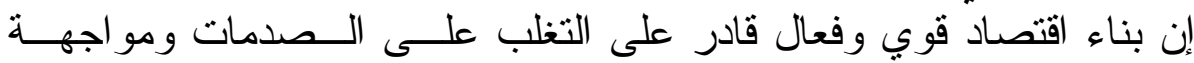

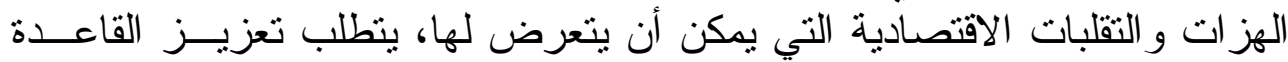

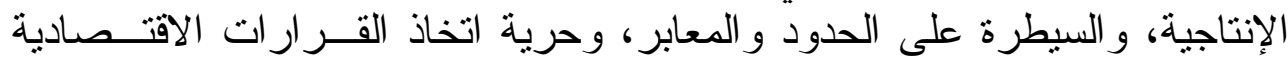

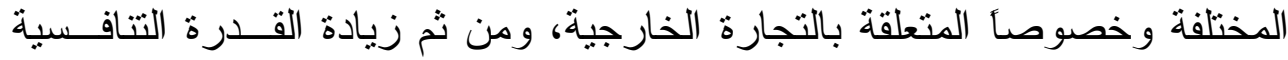

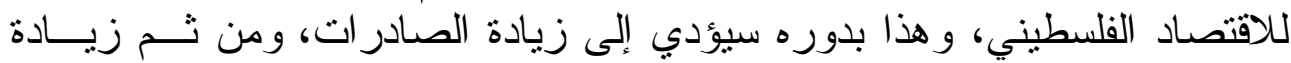




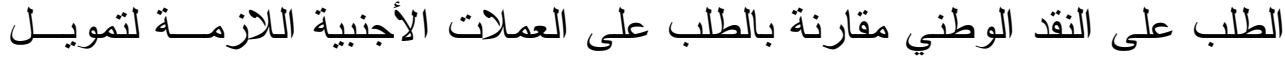

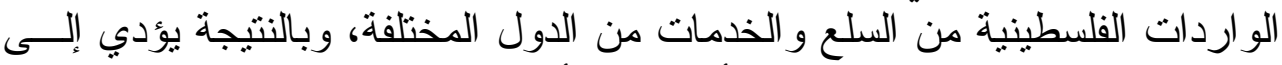

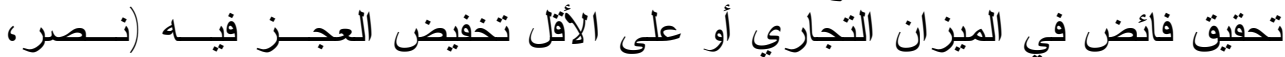
. (9 ، 9 ، 1999 هذه العملية تتطلب استكمال عملية البناء و الإعمار بخطو ات متـسـار عة فــي

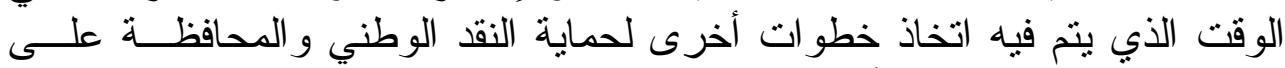

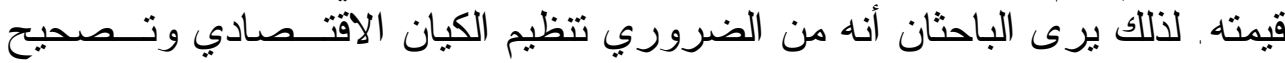

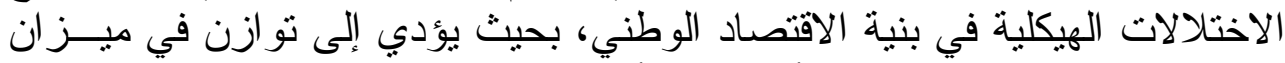

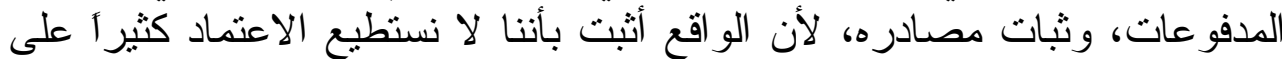

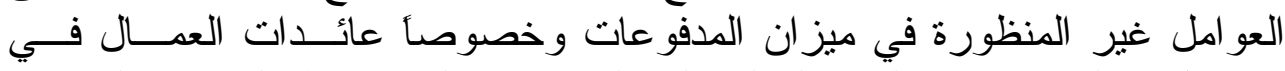

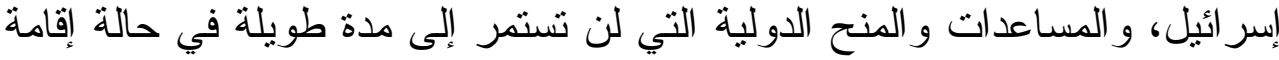

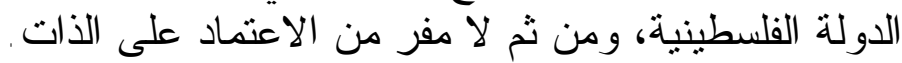

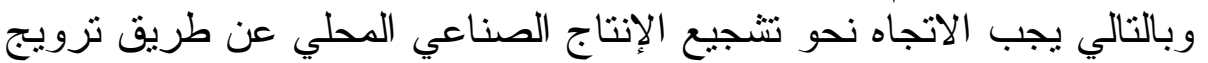

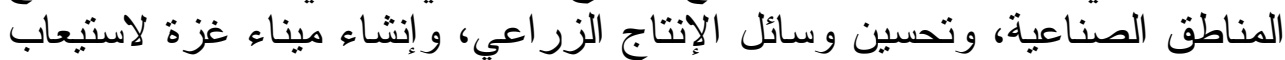

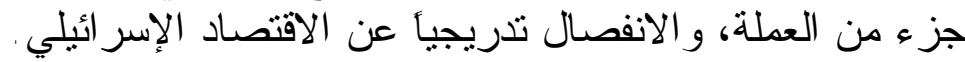
ب. وجود جهاز مصرفي قوي ولان وسليم

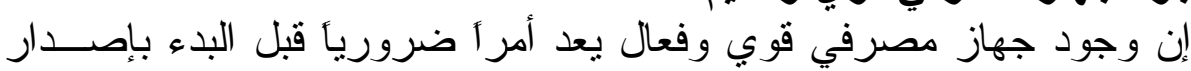

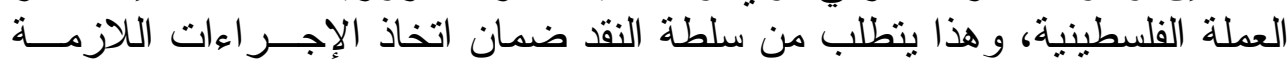

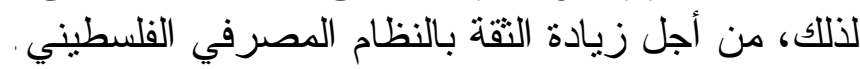

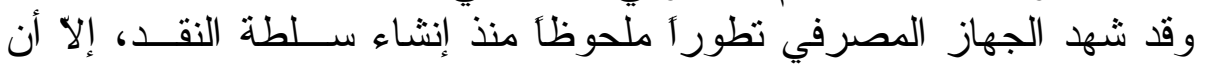

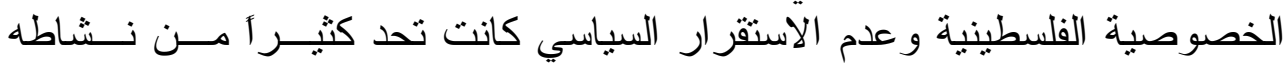

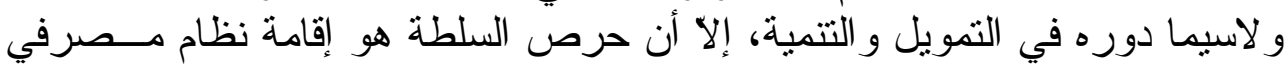

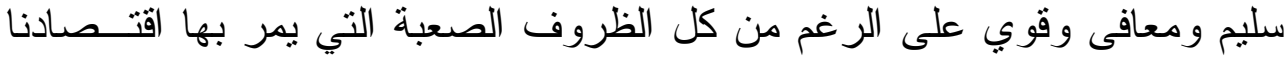

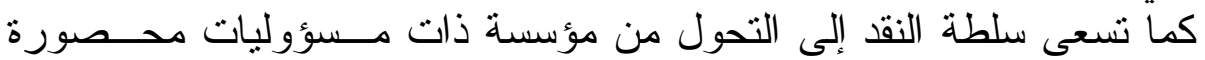

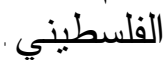

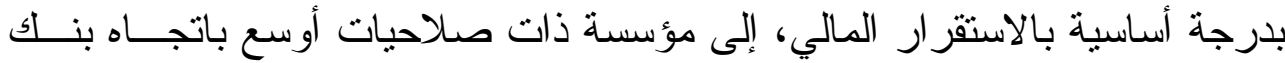

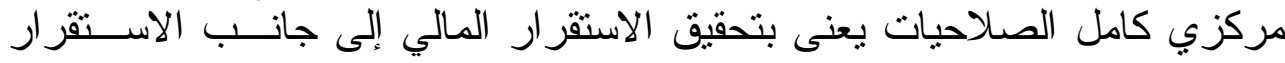

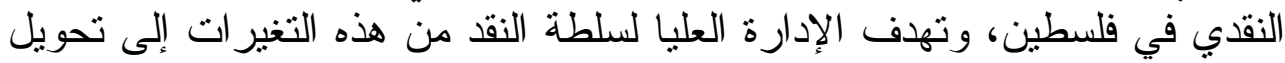

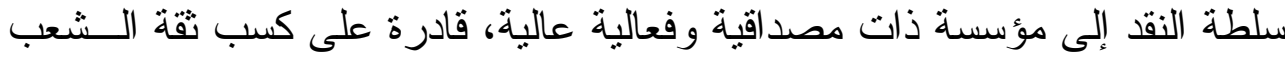

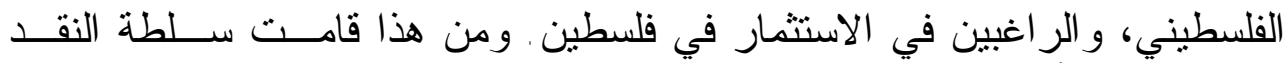

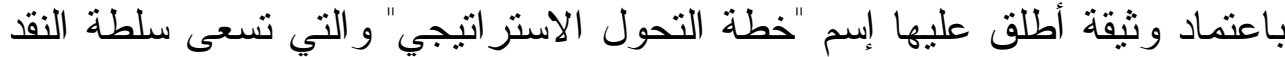

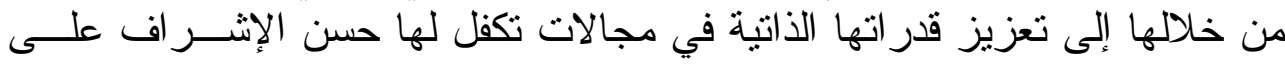

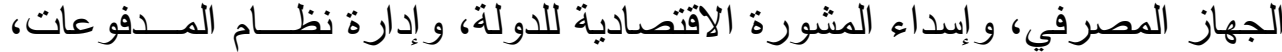

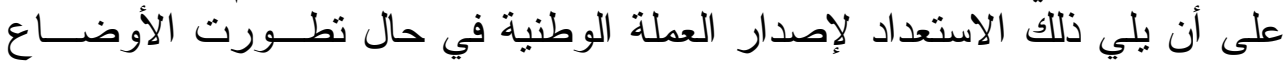

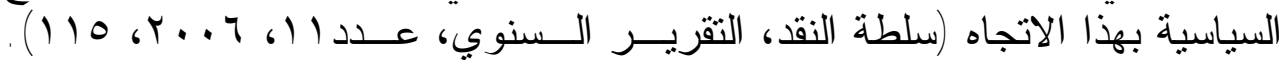

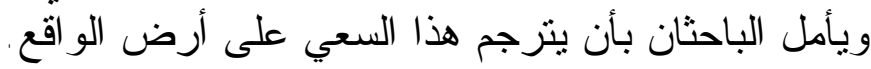


ج. بناء احتياطات نقدية كافية من العملات الأجنبية

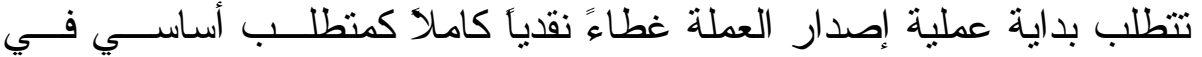

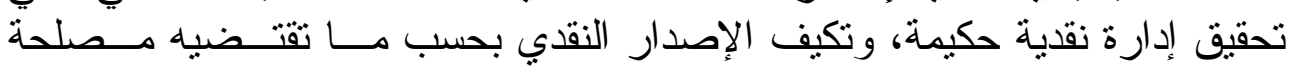

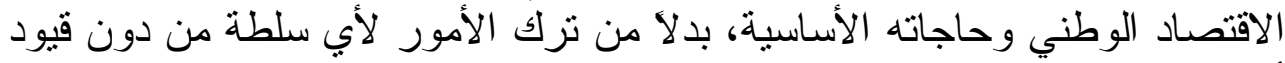

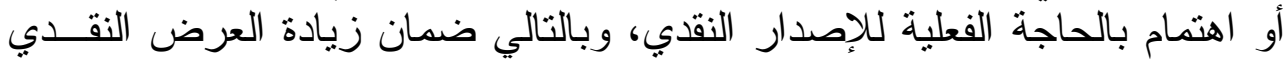

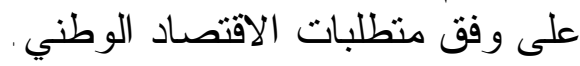
إذ إن عدم بناء احتباطات نقدية كافية من العملة الصعبة لألهات العم العملة الوطنية

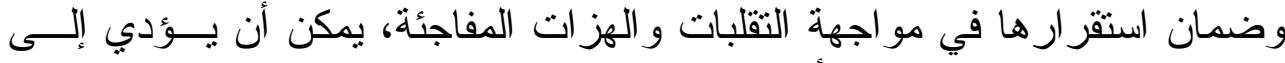

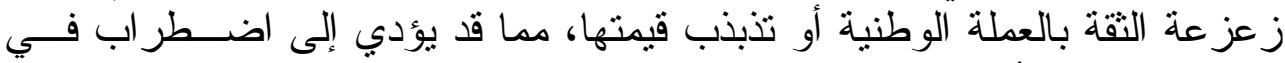

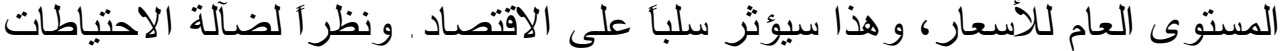

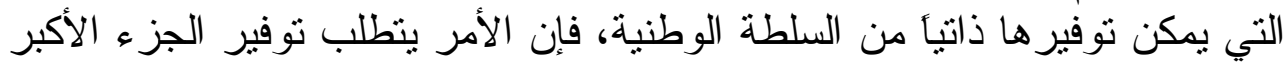

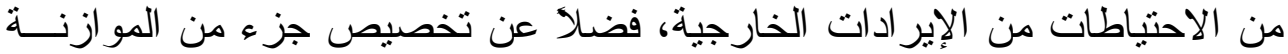

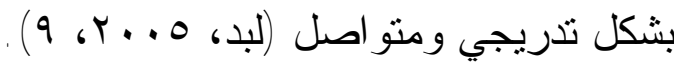

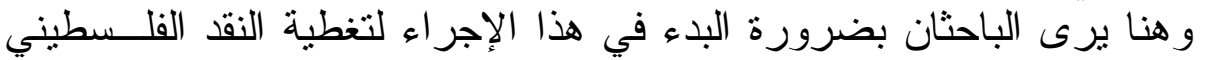

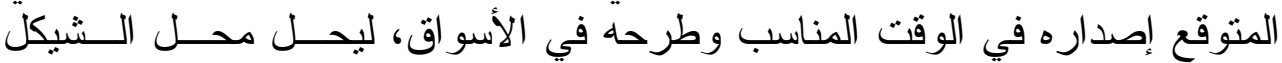

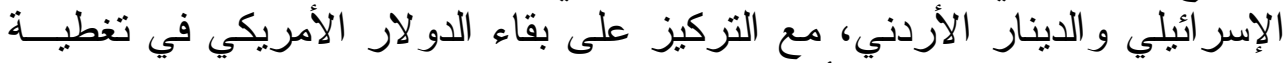

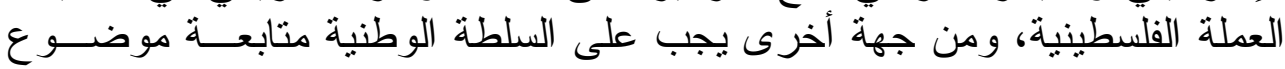

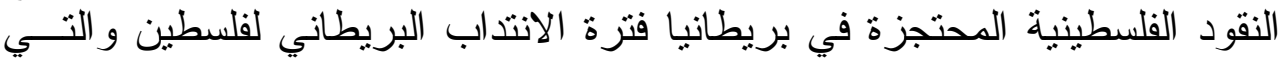

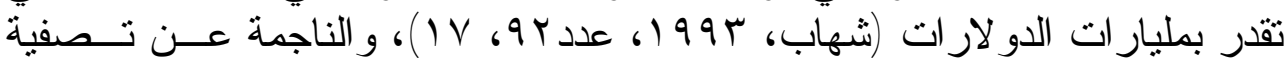

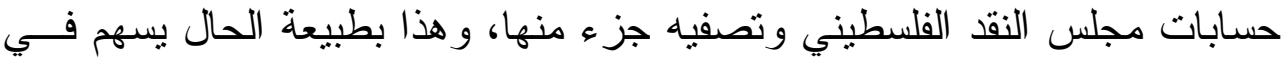

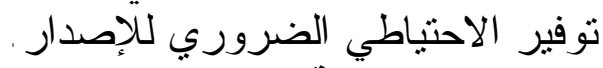

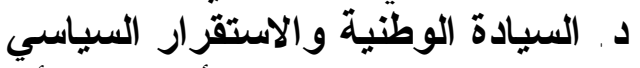

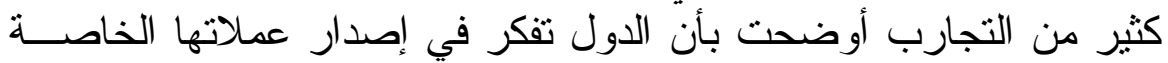

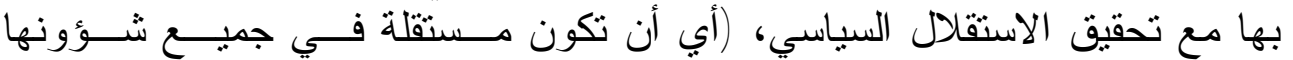

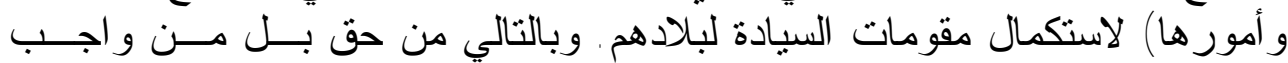

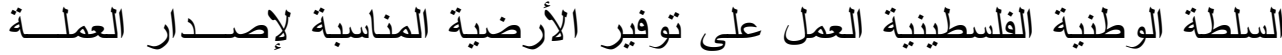

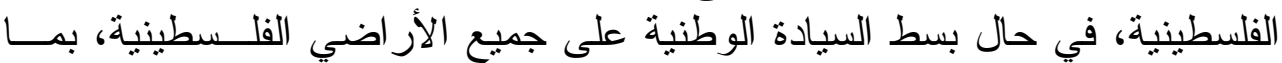

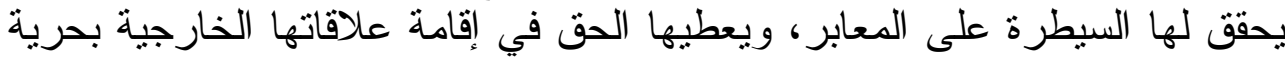
وبشكل مستقل بحسب السياسة العامة للاولة الئل

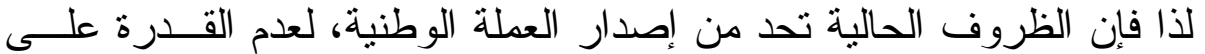

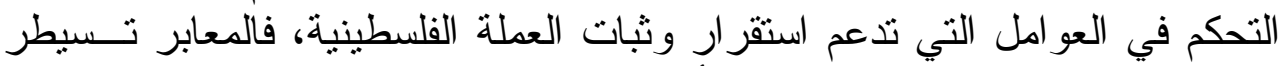

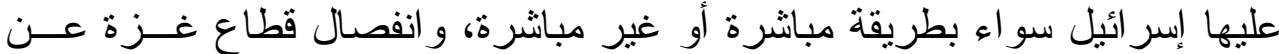

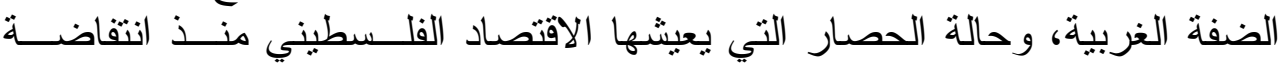

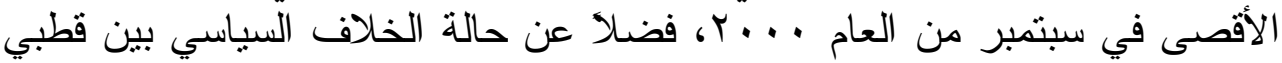

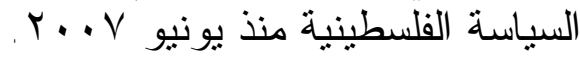




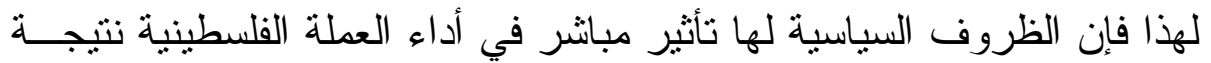

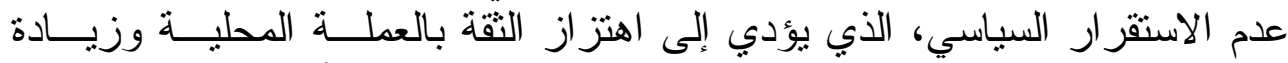

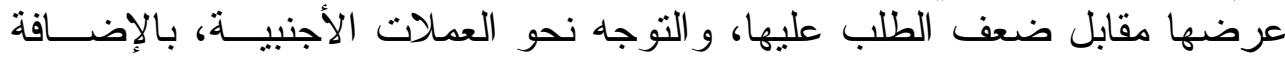

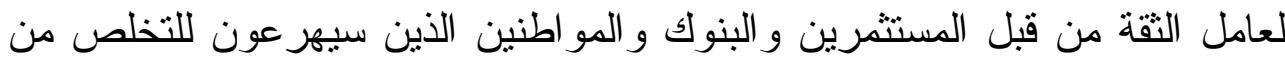

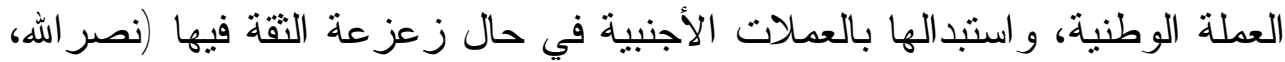

ومن جهة أخرى فإن النو احي القانونية المرتبطة بعملية الاســتقلال الـوطوطني

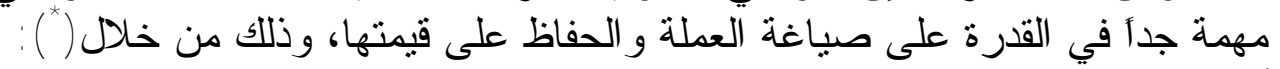
أ ـ تو افر عوامل العرض و الطلب على العلى العملة.

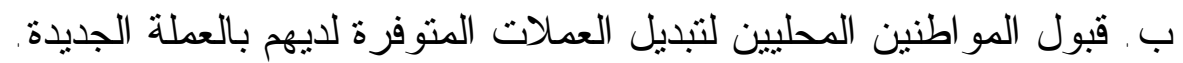

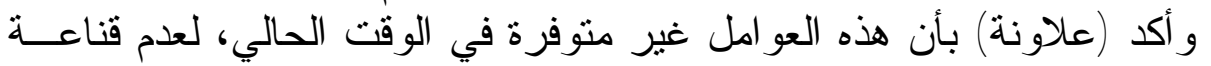

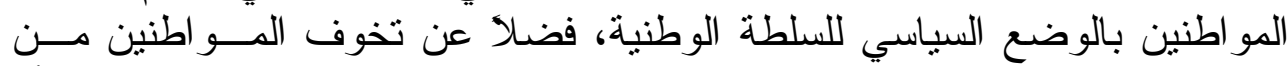

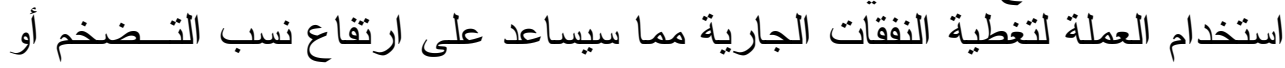

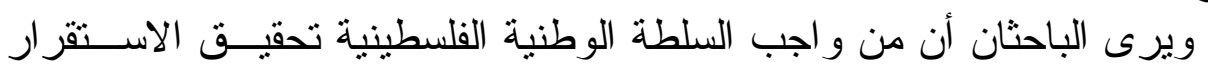

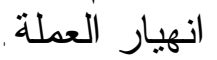

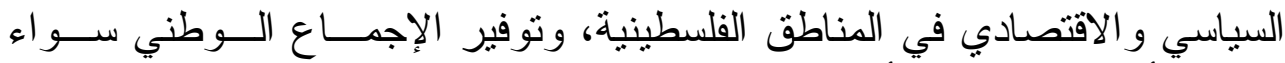

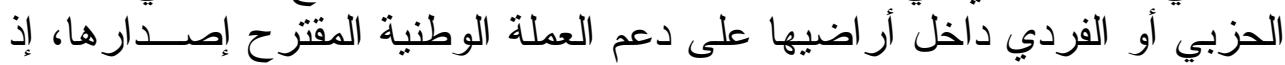

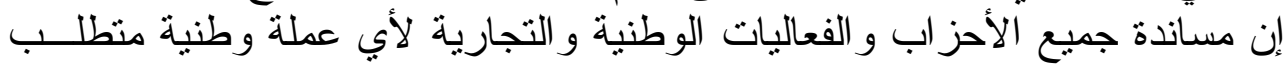

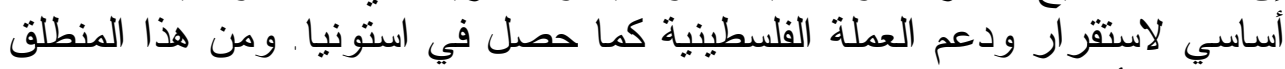

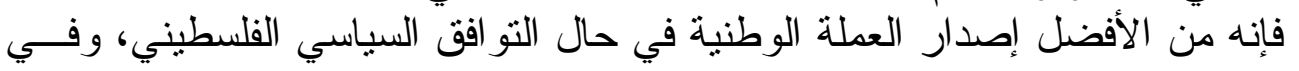

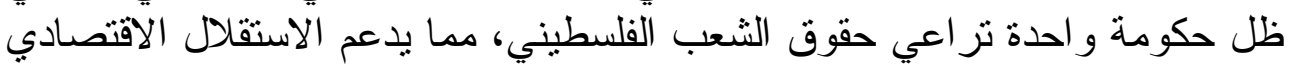
لفلسطين .

هـ استقلالية السلطة النقاية

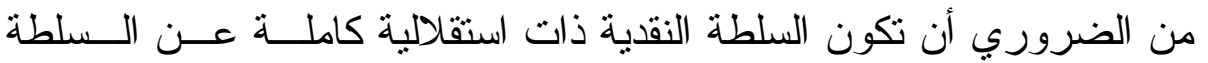

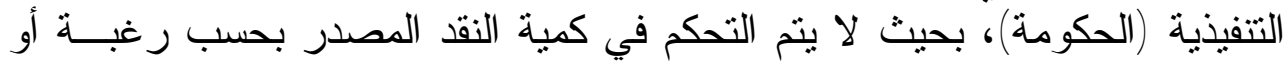

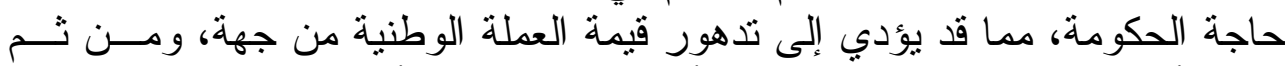

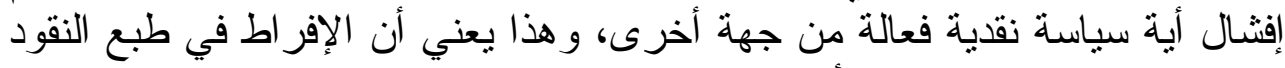

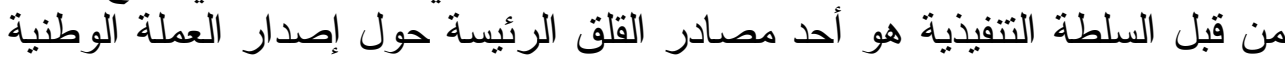

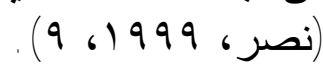

و هناك من برى بأن أحد أهم المنطلبات الرئيسية لإصدار النقد الوطني هو أن

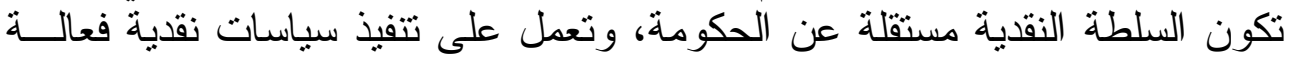

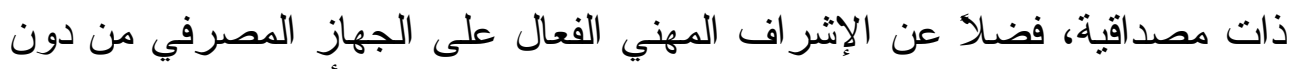
الخضوع للاعتبار ات السياسية المختلفة التي قد تؤثر سلباً في أداء الجهاز المصرفي

\footnotetext{
(") مقابلة مع د. عاطف علاونة، وكيل وزارة المالية سابقا، ومدير عام هيئة سوق رأس المـال

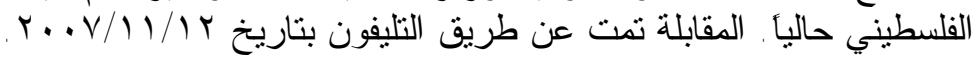




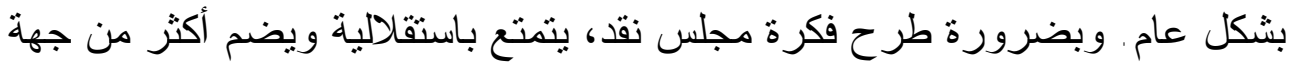

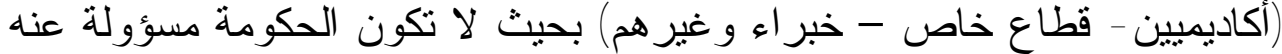

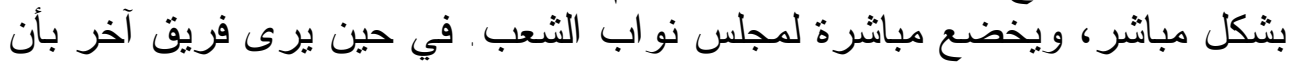

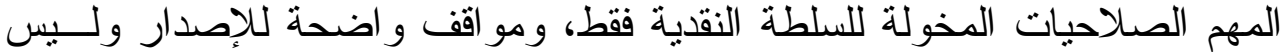

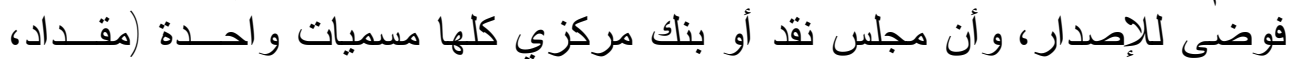

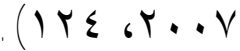

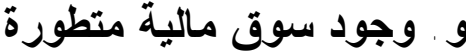

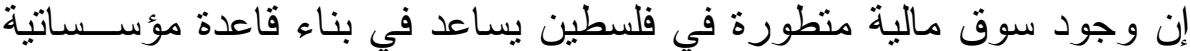

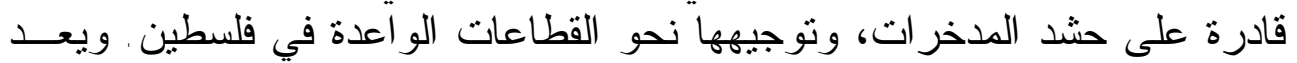

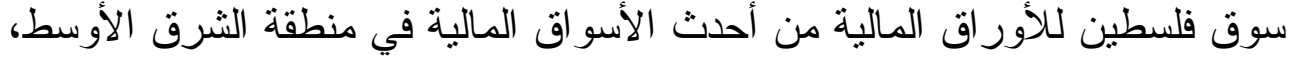

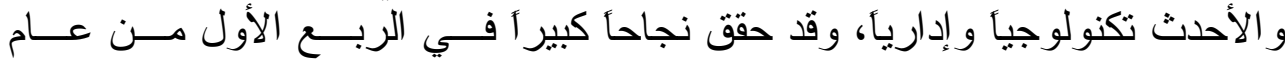

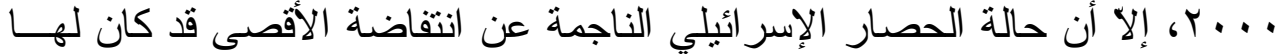

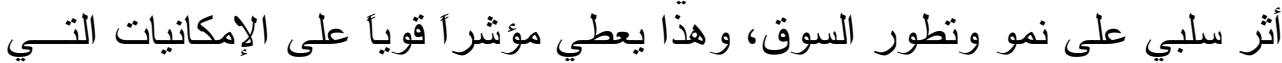
يتمتع بها السوق، لو لا الظروف السياسية التي أثرت مون على أدائه.

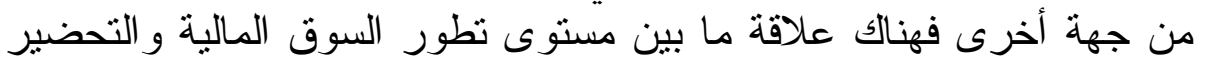

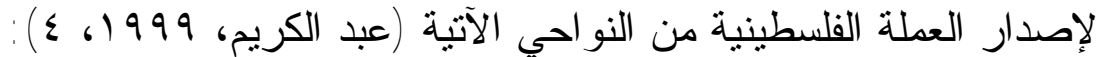

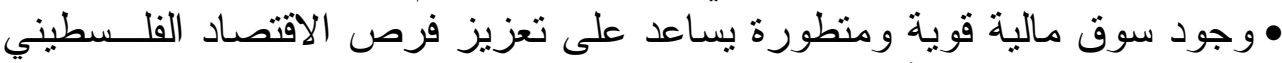

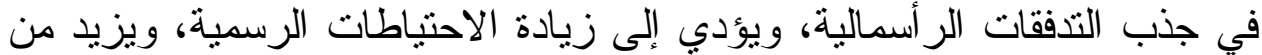
قدرة الاقتصاد على امتصاص أثر الصدمات التئل المحلية و الخارجية.

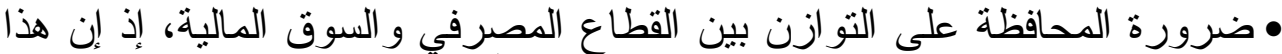

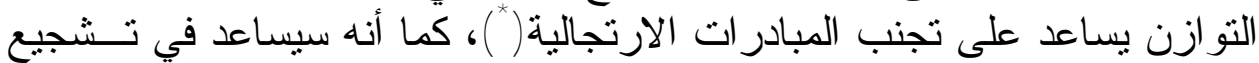

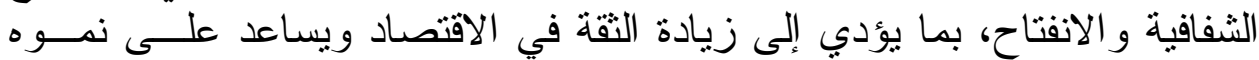

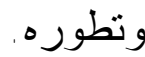
• تطور السوق المالية يعد أمرأ ضروريأ لتعزيز قدرة السلطة النقدية في اســتخدام

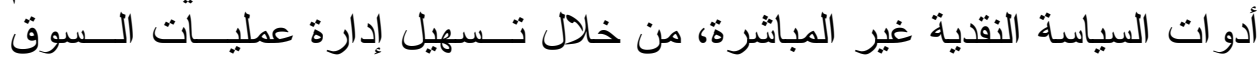

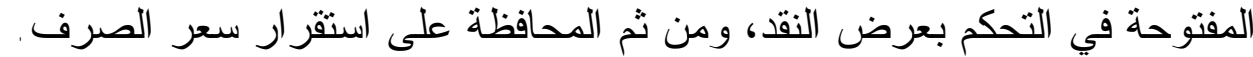

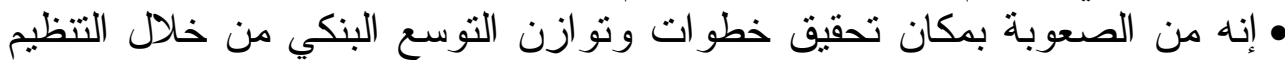

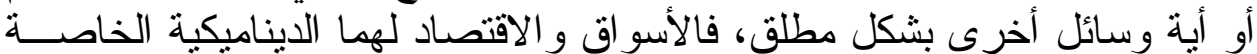

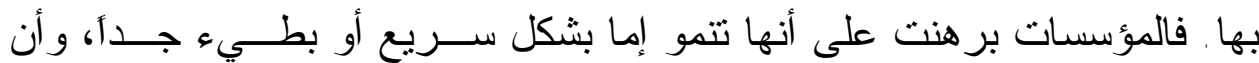

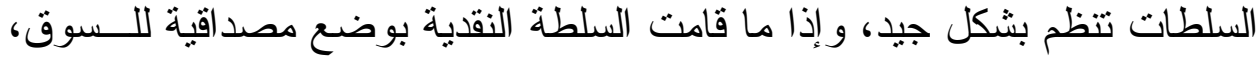

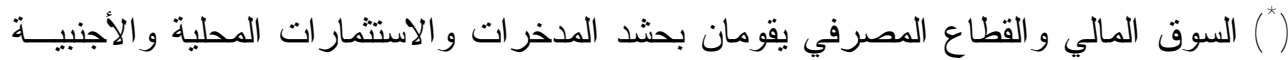

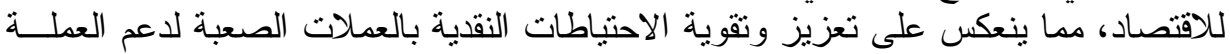

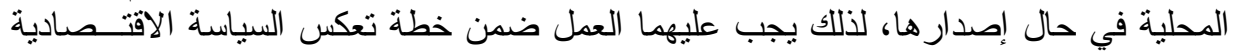


فإن الأزمة إذا ما نشأت يمكن السيطرة عليها بشكل أفضل. وفيــي المقابـلـ، إذا

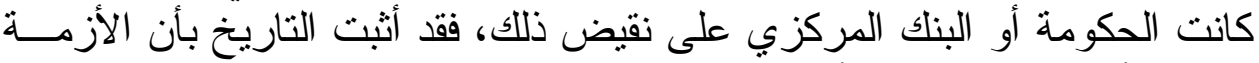

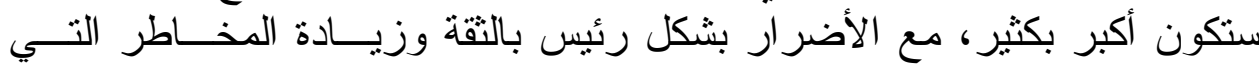
تضعضع الاقتصاد و الأستقر ار الاجتماعي (Axiltod, 1999, 20).

\section{ز. ثقة المواطنين وتقبلهم للعملة المطلوب إصدارها}

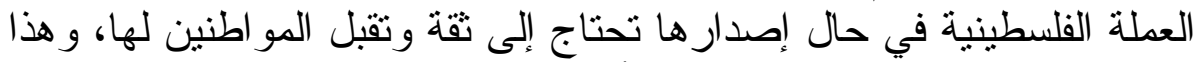

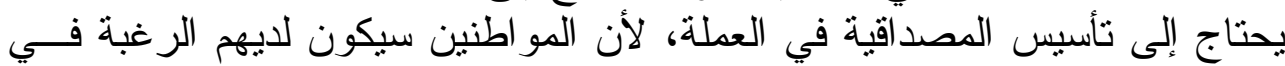

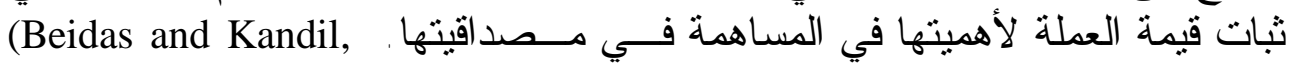
.2005, 22 )

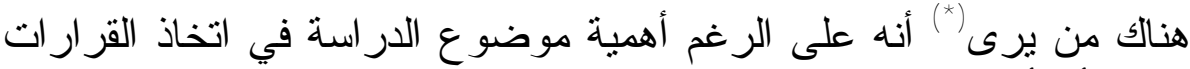
السليمة، إلا أن أهم شيء في عملية إصدار العملة الوطنية هو ثقة وتقبل الهبل المو اطنين للتعامل معها.

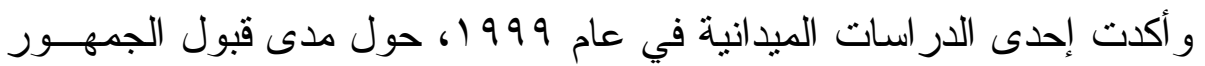

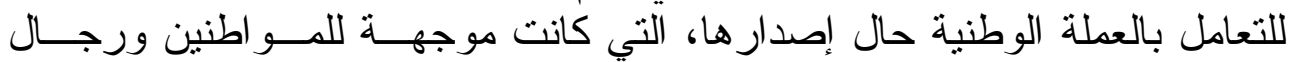

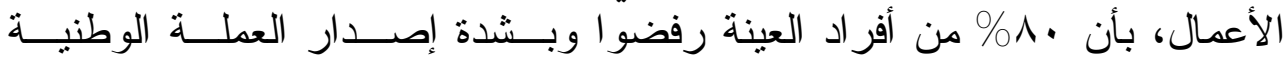

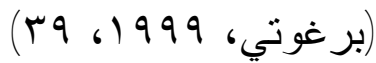
تم استقصاء ر أي عينة من المو اطنين في قطاع غزة لمعرفة فئه مدى ضــرورة

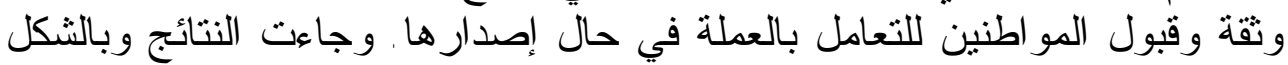
التالي : و

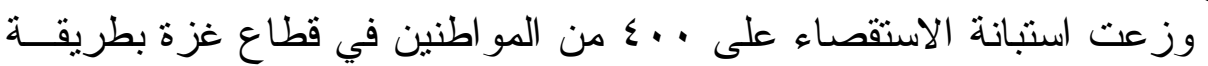

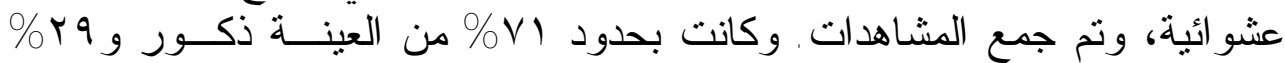

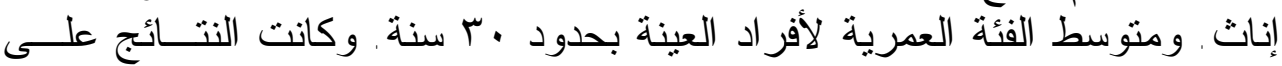

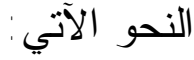

$$
\text { ثامناً - اختبار رأي المواطنين حول الإصدار النقدي }
$$

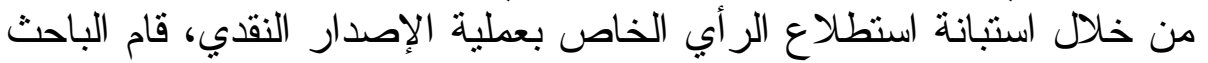

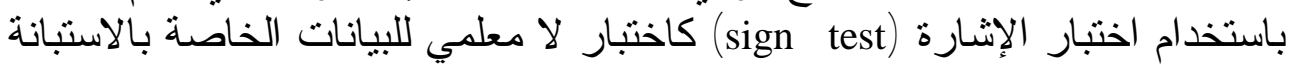

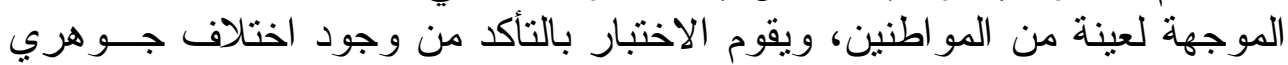

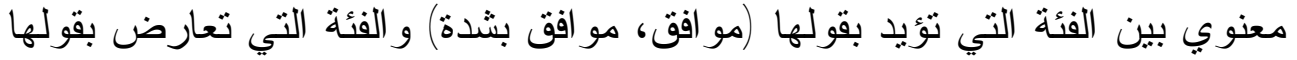

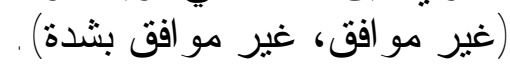

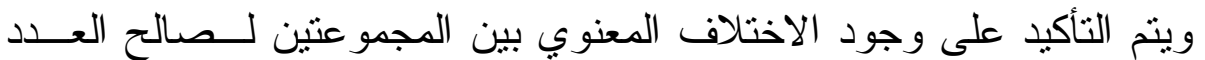

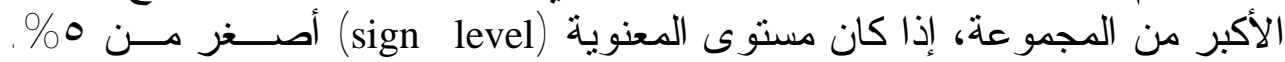
و عليه فالجدول (ع، r ب) رقم يبين مدى معنوية الاختلاف بين الفئنين .

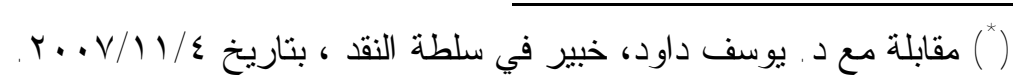




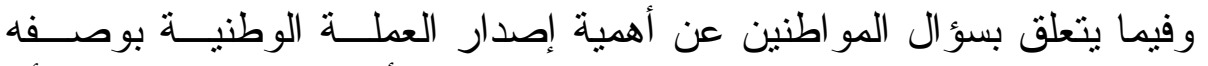

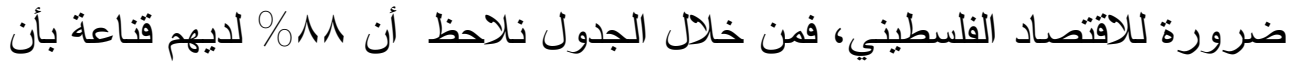

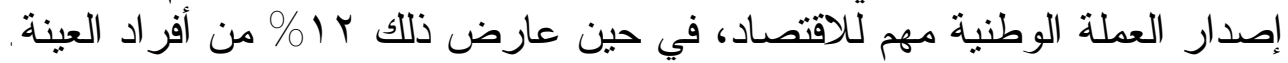

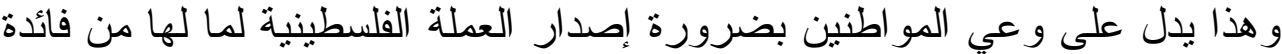

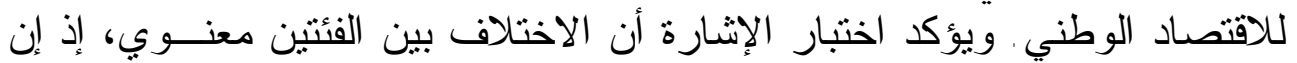
درجة المعنوية = ( ( ., •).

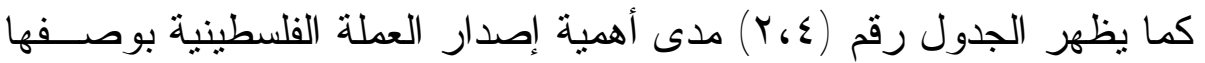

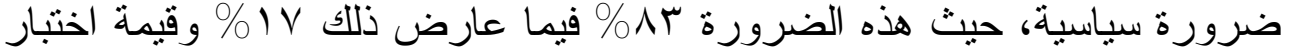

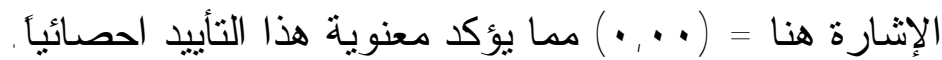

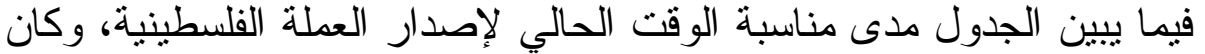

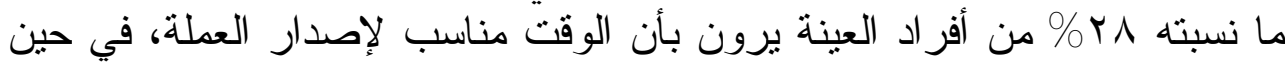

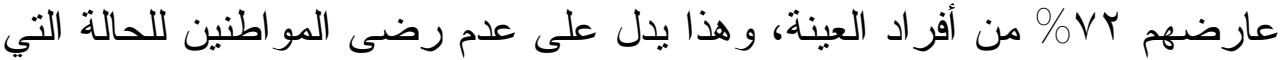

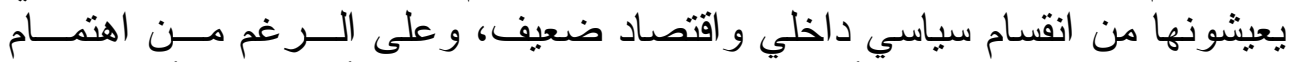

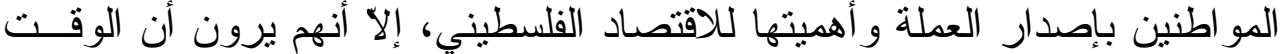

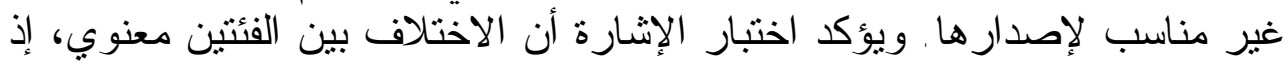
إن درجة المعنوية = ( (., •). ويوضح الجدول أيضاً نقة المو اطنين بالعملة في حال إصدار ها، وتبين النتائج

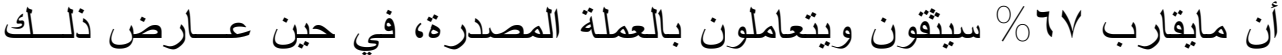

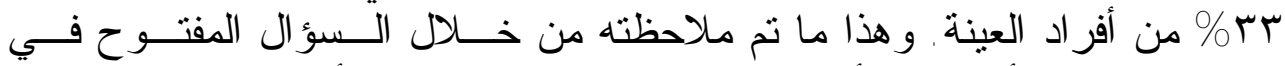

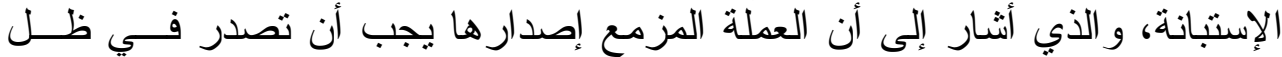

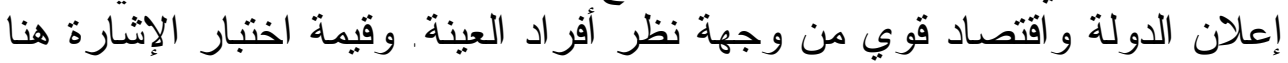

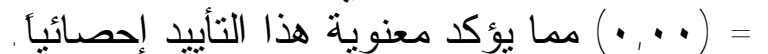

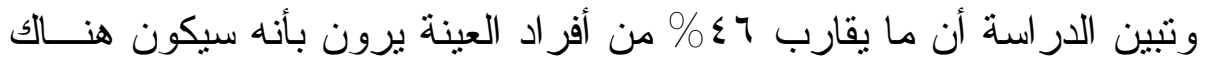

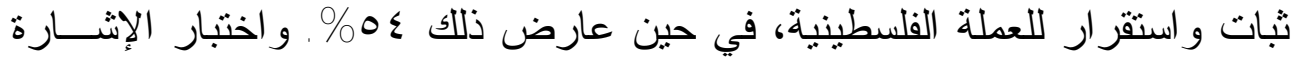
يبين أن الاختلاف بين المؤيدين و المعارضين ليس معنوين لئن من الناحية الإحصائية. 


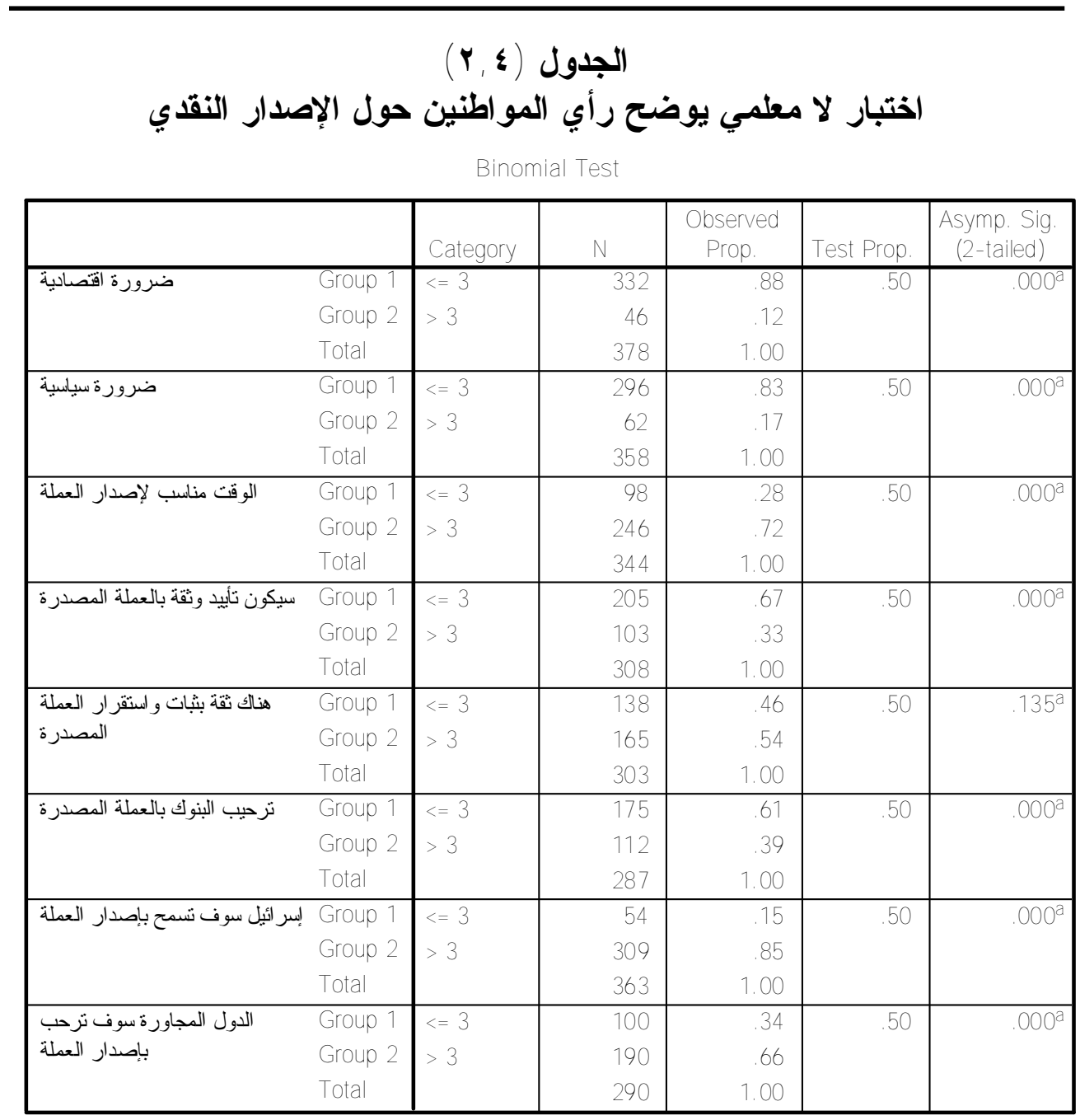

a. Based on Z Approximation.

ويرى اب7\% من أفر اد العينة أن البنوك سترحب بالعملة الفلسطينية وتتعامل

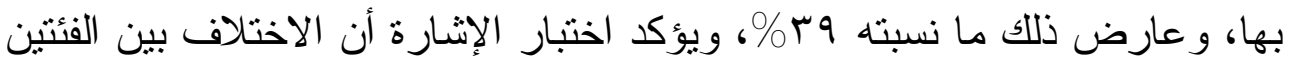

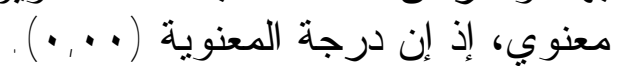

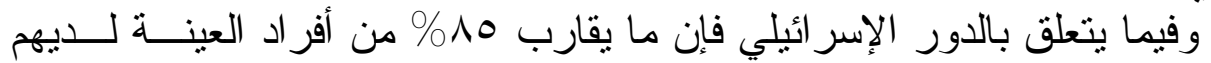

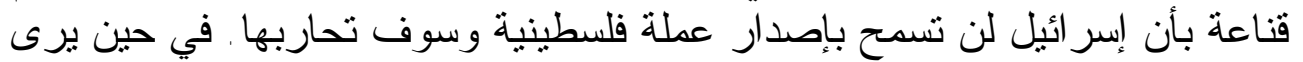

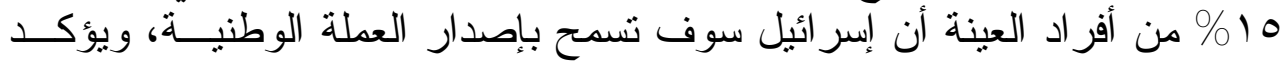

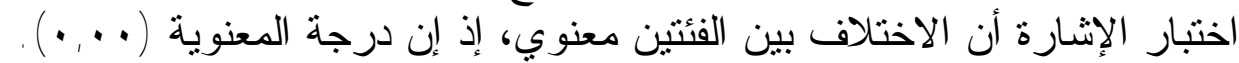

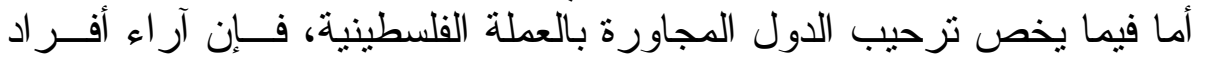

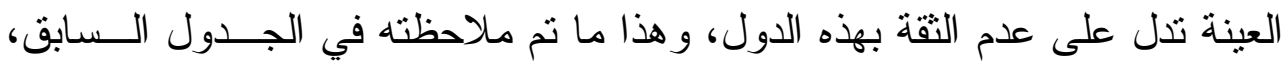

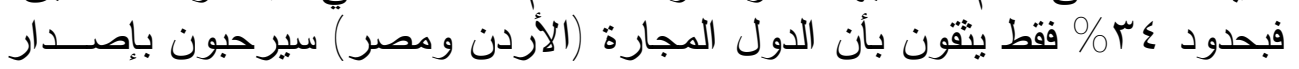




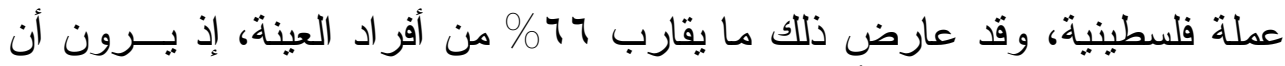

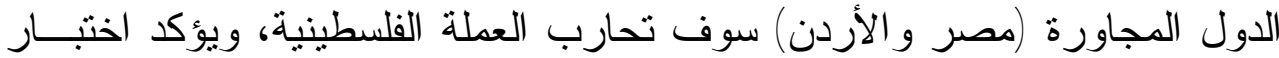

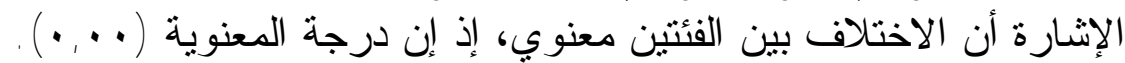

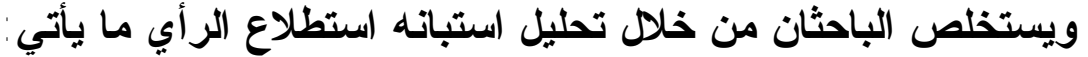

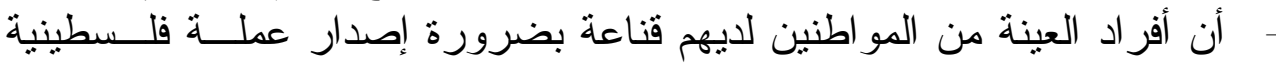
كضرورة اقتصادية وسياسية.

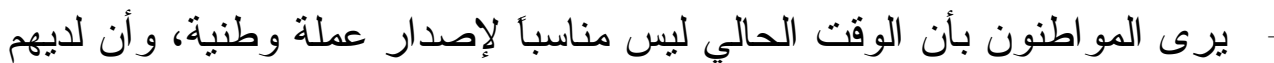
همومأ أكبر من التفكير بإصدار عملة فلسطينية (اقتصاد ضعيف وبطالة الفيلة عاليــة

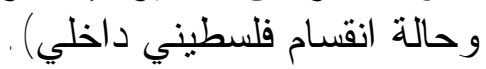

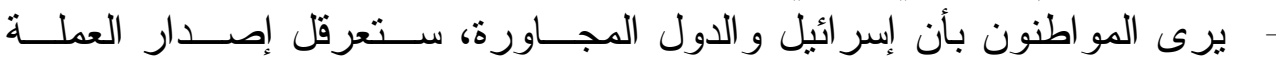

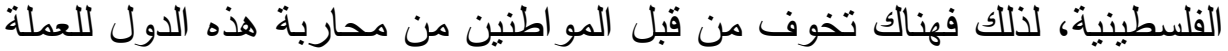

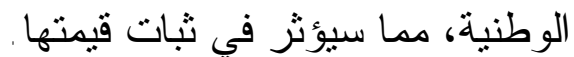

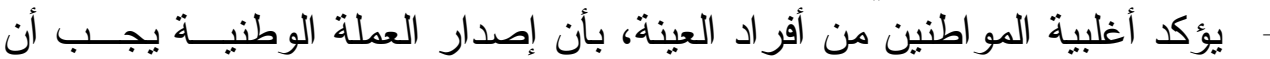
يكون في ظل وجود اقتصاد قوي ووضع سياسي ملائم .

تاسعاً - البدائل النقدية المتاحة و البديل الأمثل

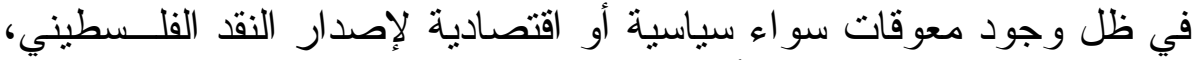

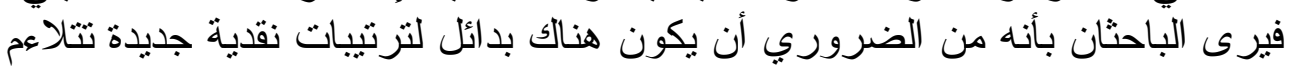

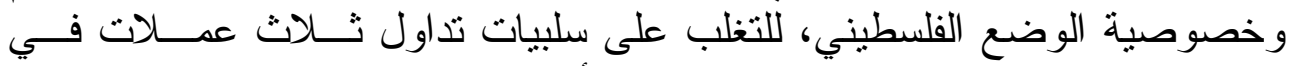

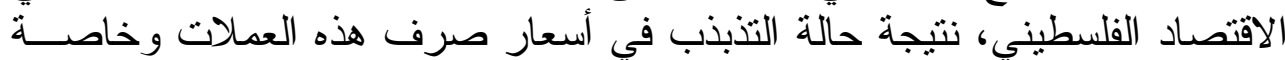

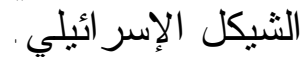

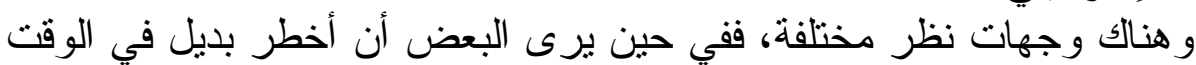

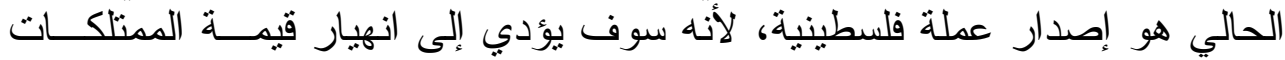

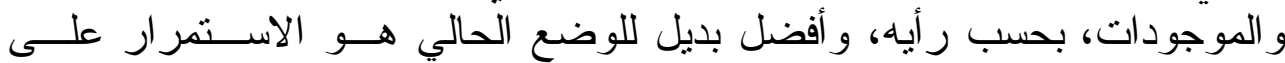

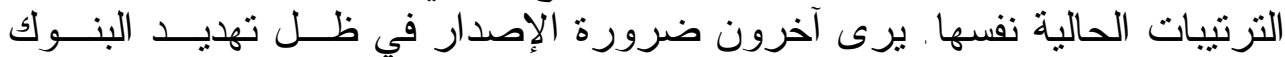

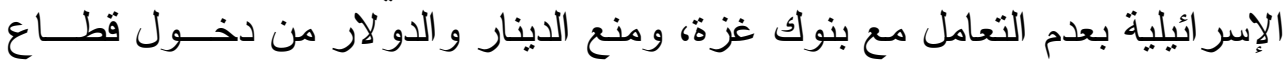

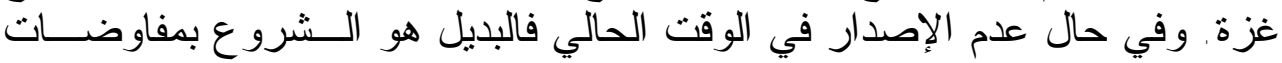

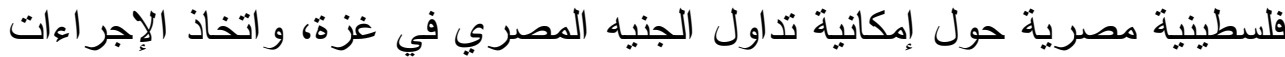

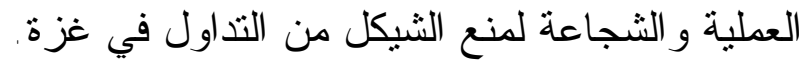

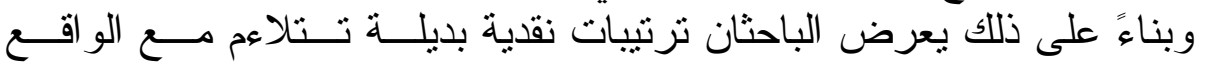

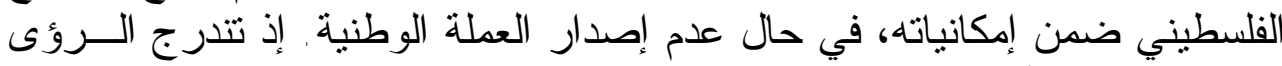

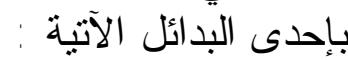
1. اتحداد نقدي مع الأردن: هنالك رأي ينادي بتفضيل الابقاء على اعنبار الــدينار

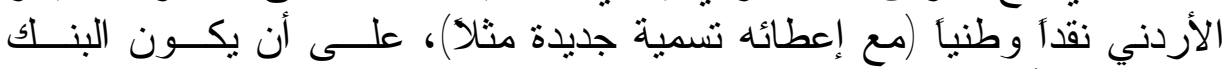
المركزي الأردني هو السلطة النقدية ذات العلاقة (صامد الاقتصادي، 1990 19، 


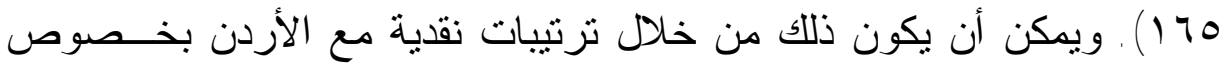

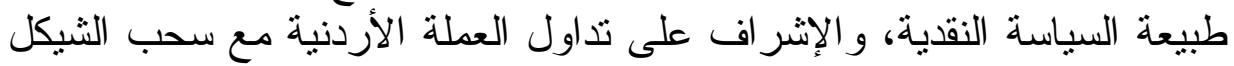

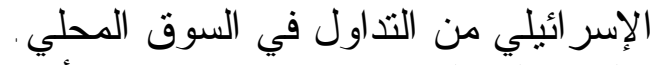

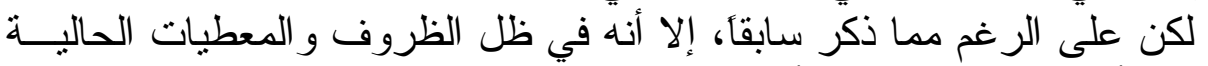

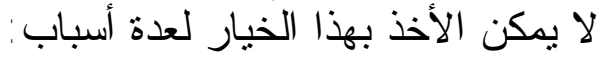

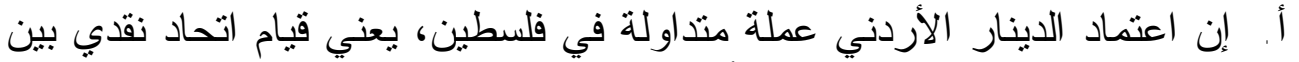

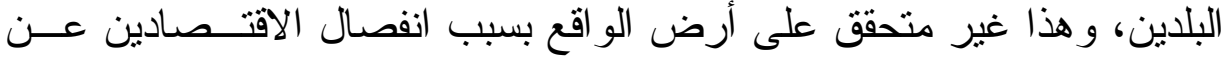

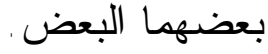
ب. إذا نم تطبيقه فإنه يمكن أن يطبق في الضفة الغربية، أما غزة فنتيجة بعدها عن

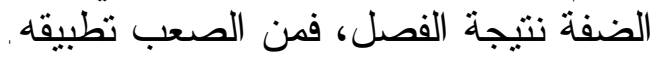

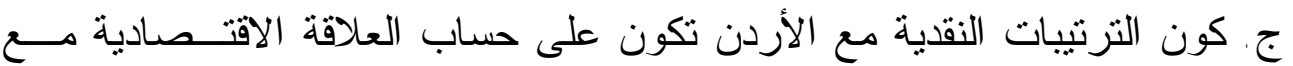

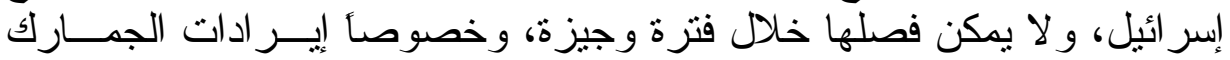

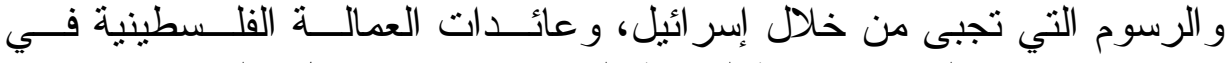

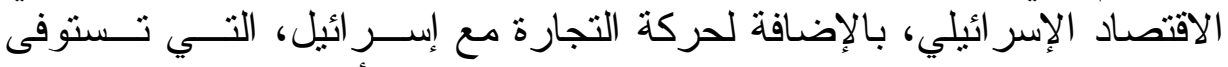

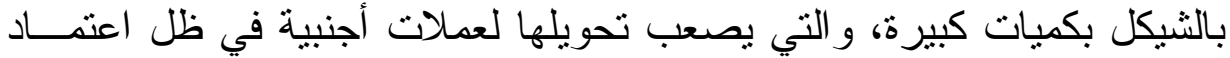

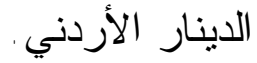
r. اتحاد نقدي مع إسر ائيل: هذا الخيار ينبع من العلاقة الاقتصادية المفروضة على الحئ

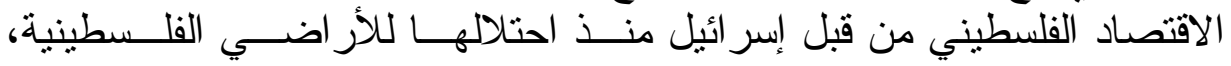

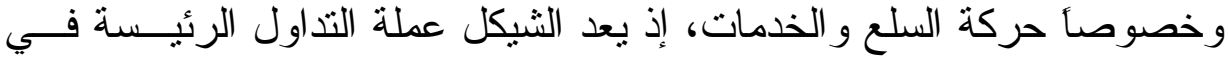

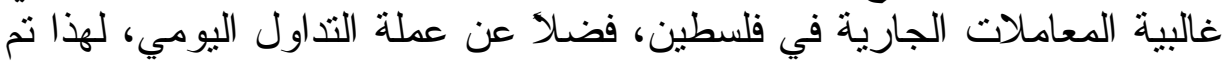

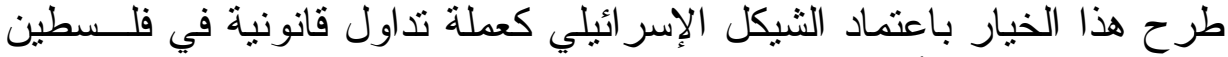

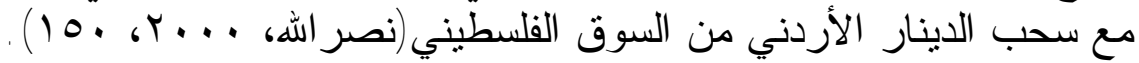

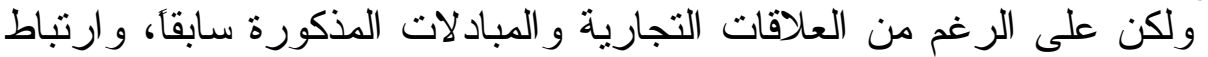

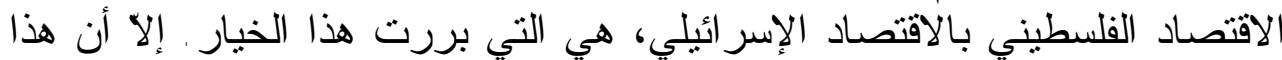
الخيار إذا تم تقبله سياسياً و اقتصاديأ، فلا يمكن تقبله نفيله نفيأ وشعبيأ للأسباب الآتية:

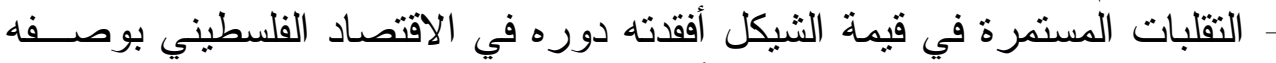

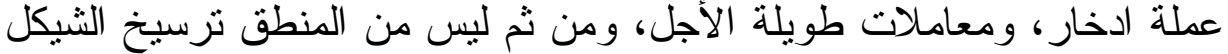
الإسر ائيلي في الاقتصاد الفلسطيني بسلبياته المتعددة.

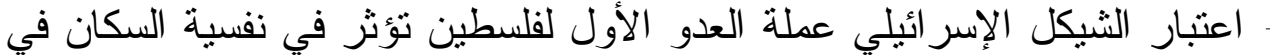

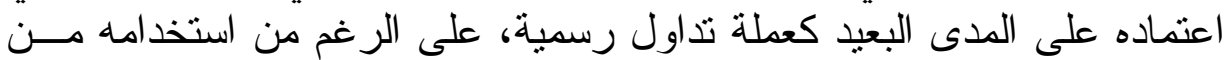

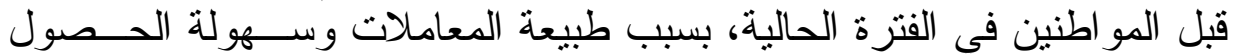
عليه بمصادره المختلفة. r. دولرة الاقتصاد : قامت بعض الداديه لالدول بدولرة اقتصادها عوضأ عن إصدار عملتها

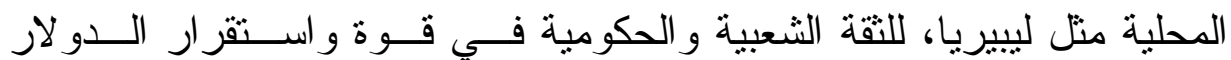
الأمريكي، وبالتالي اعتماده عملة تداول قانونية رئيسة لتسيير معاملاتهم الجارية

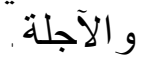


يمكن تحقيق الدولرة من دون الحاجة لمفاوضات ومباحثات محتملة الصعوبة

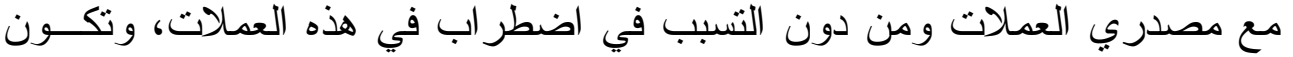

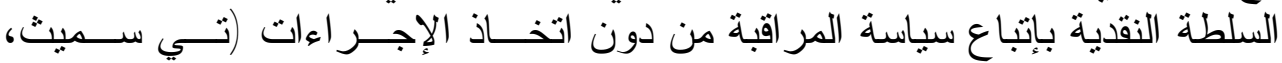
. (r 6) 1999

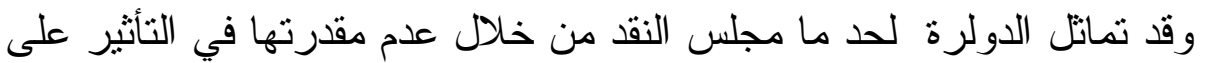

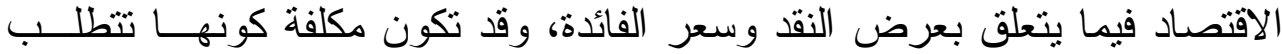

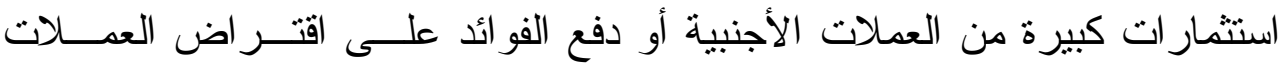

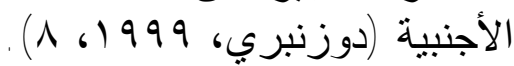

مع هذا قررت إحدى دول أمريكا اللاتينية بدولرة عملتها المحلية، فيما برزت

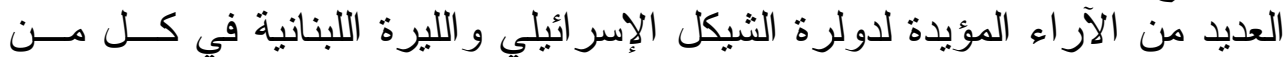

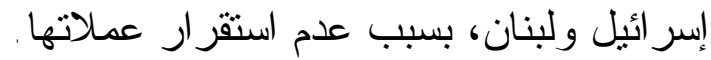

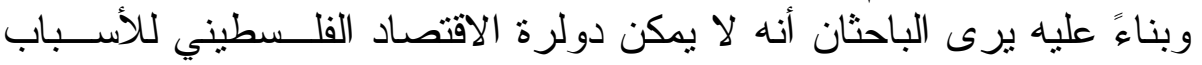

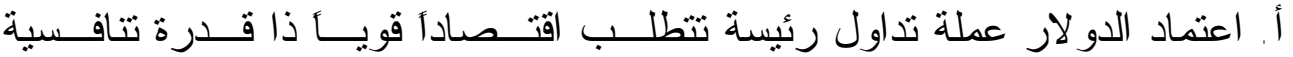

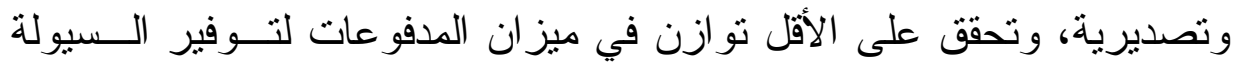

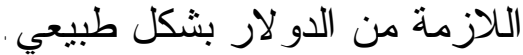

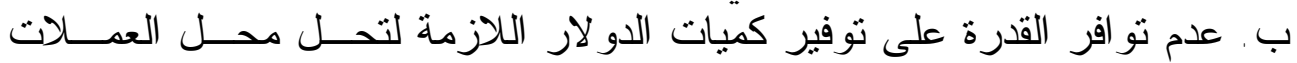

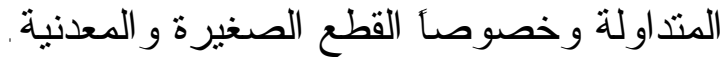

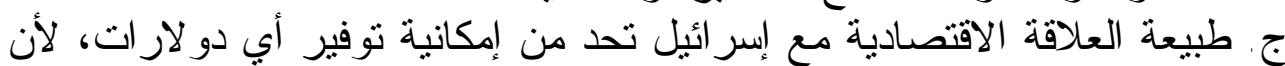

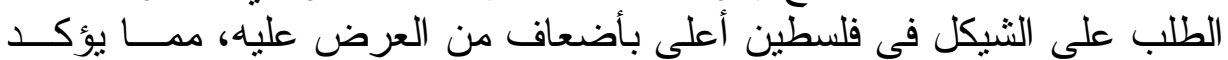
وجود عجز في توفير العملة الصعبة، ومن ثم فيكي عدم إمكانية تطبيق هذا الخيــار في الوقت الحالّي . توني

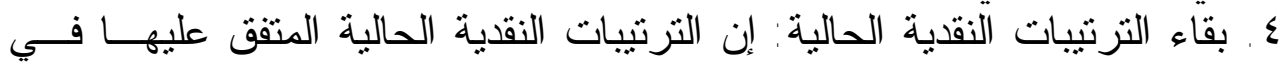
اتفاقية باريس الاقتصادية، و الاتفاقية الاقتصادية مع الأردن حول تداول الدينار

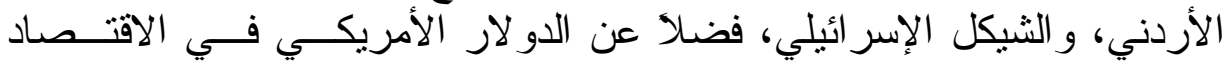

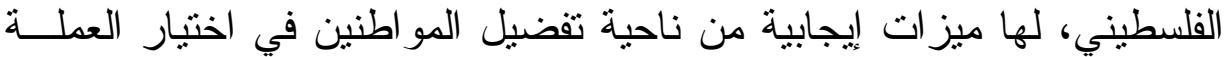

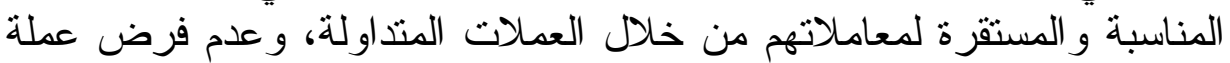

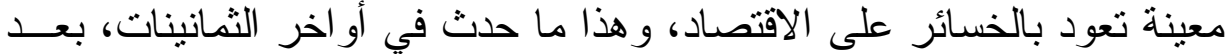

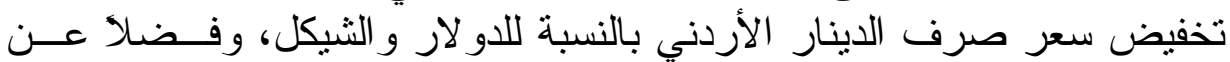
الاعتماد على الدينار و الدو لار خلال فتر ات التضخم في الثنيكل الإسر ائيلي .

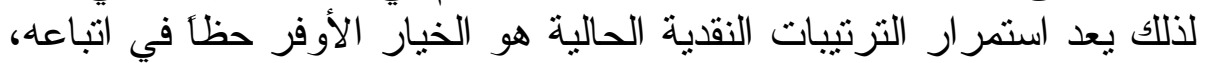
ولكن ضمن اتفاقيات جديدة تأخذ بعين الاعتبار النقاط الآتية:

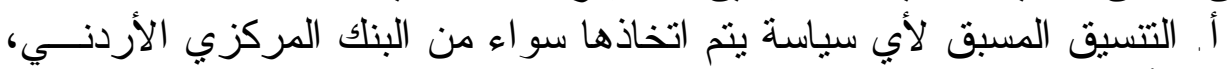
أو بنك إسر ائيل للتأثنير في عملاتها. 
ب . المطالبة بحصة فلسطين من عو ائد الثيكل و الدينار المتداولة في فلسطين، و هي خسائر مباشرة من مواردنا الاقتصادية لحساب الاقتصاد الإســـر ائيلي

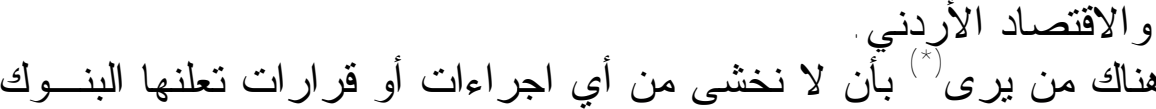

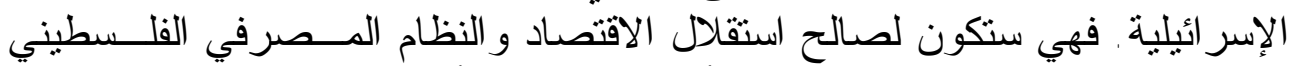

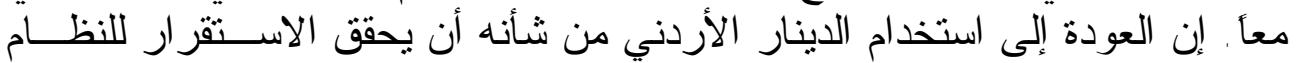

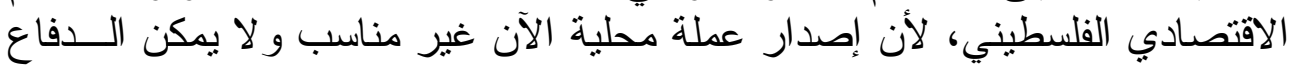
عنها وحمايتها، لأننا حتى الآن ما زلنا نحصل على الآلى رواتبنا من المساعدات الأنس الأجنبية

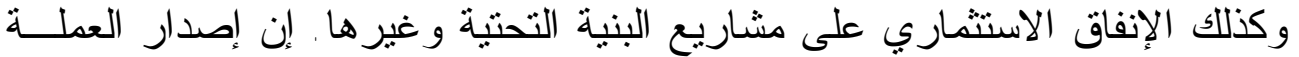

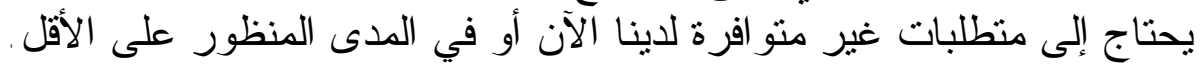

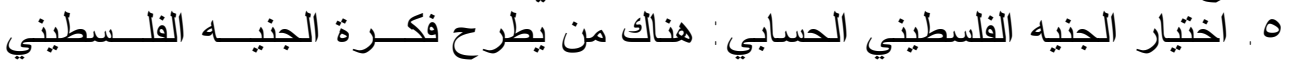

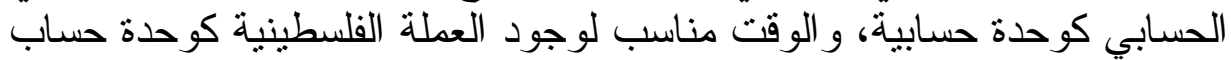
كما كان الحال في الايكو أو الدينار العربي الحسابي، فالبده في في استخدام الجنيه

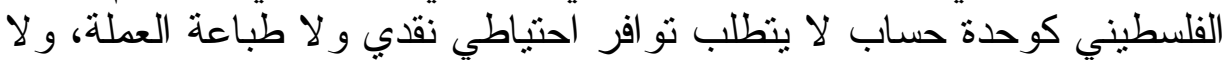

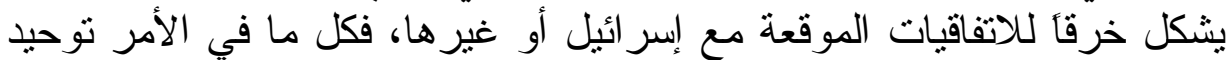

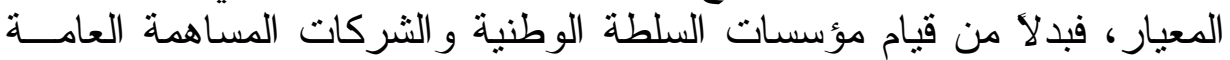

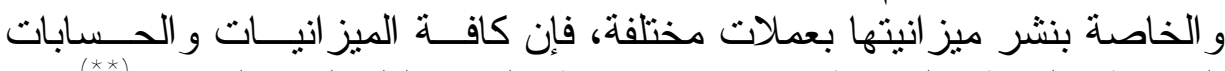

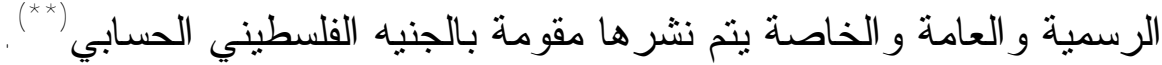

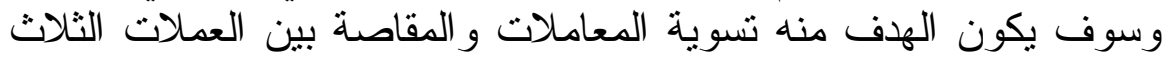

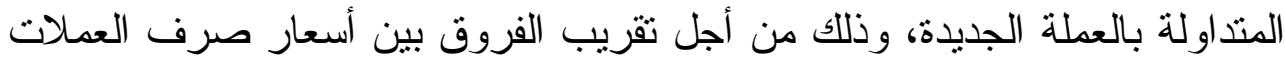

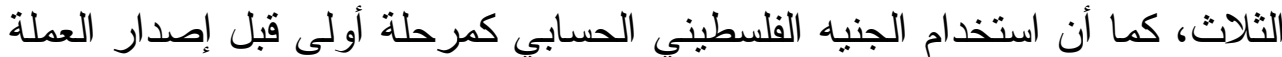

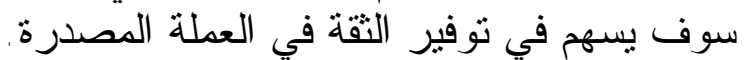

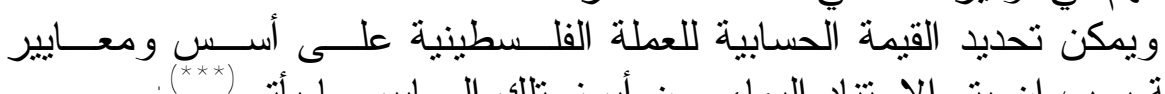

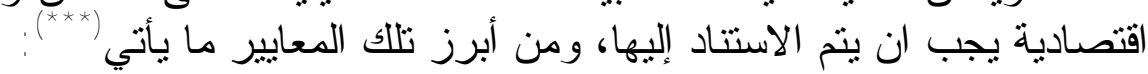

- كمية النقد المتداول من العمات المختلفة في الاقتصاد الفلسطيني. - الناتج المحلي الإجمالي للدول المقترحة إدخال عمالتها في سلة العمدات الندات النقدية.

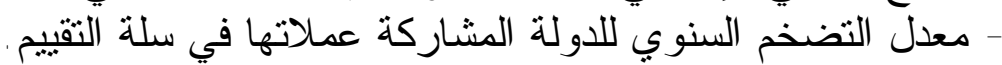

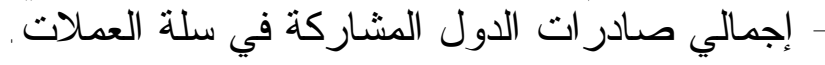

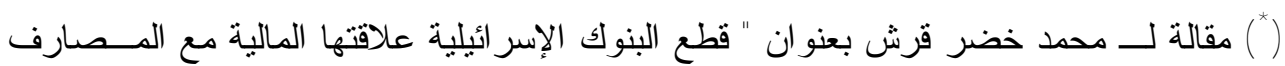

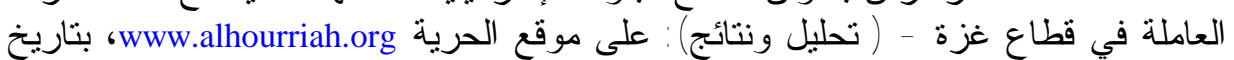
( ) مجلة البنوك في فلسطين، مجلة شهرية متخصصة في الثؤون المـصرفية، العـدد الأول، يونيو اليجلة الينوك 1997.

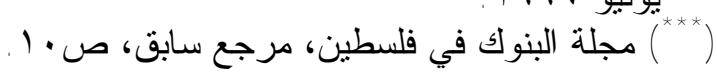




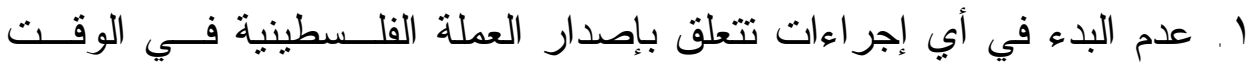

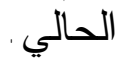

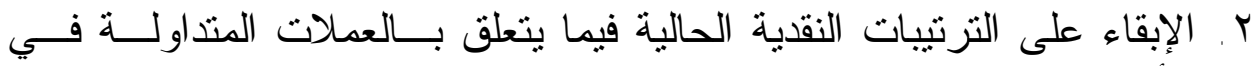

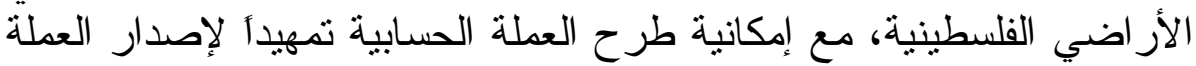

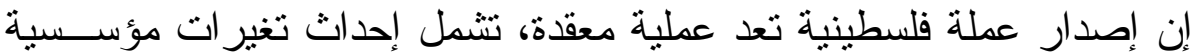

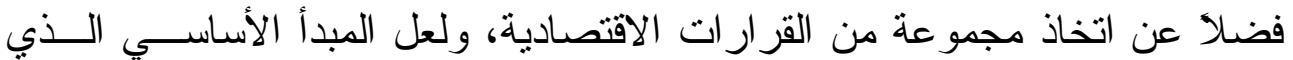

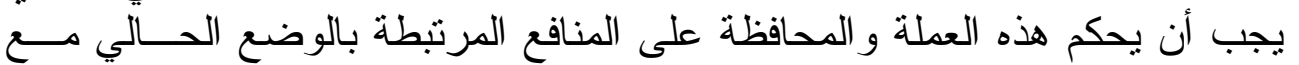

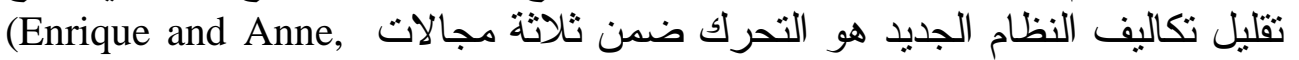
:1999, 14)

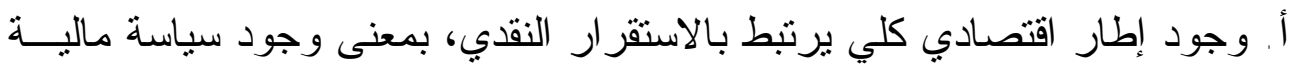

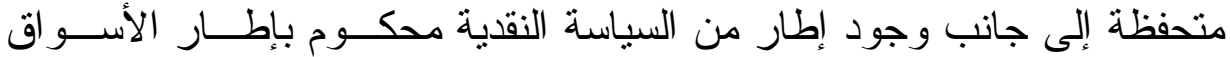
الكفو عة.

ب. اختيار نظام سعر الصرف الثابت الذي يحقق أعلى مــصداقية، ويقلـلـل مــن التكاليف و التتويشات المرتبطة بطر ح العملة الجديدة.

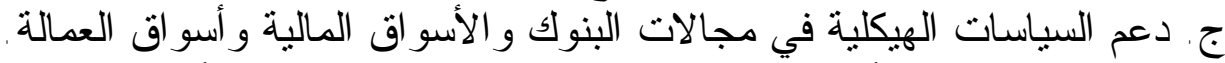

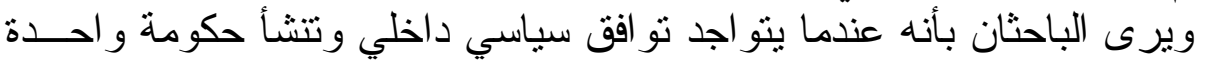

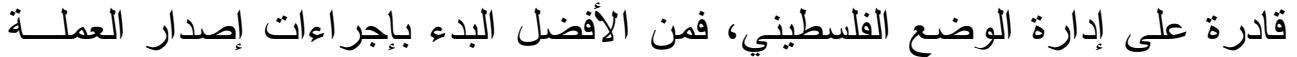
الوطنية للادولة الفلسطينية.

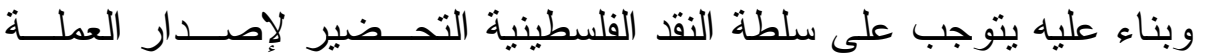

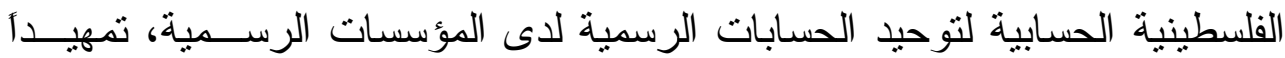

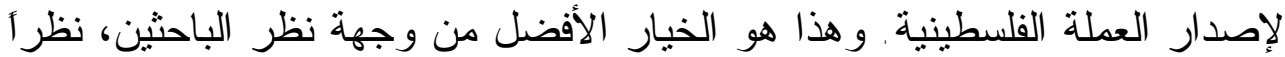

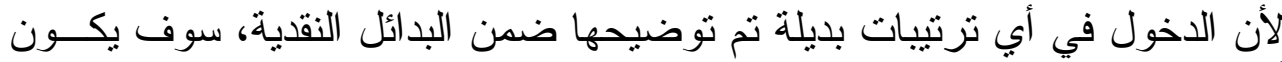
أصعب من عملية إصدار العملة الفلسطينية.

\section{عاشر آ - التوصيات \\ 1 أسلطة الوطنية الفلسطينية}

- أن تعمل السلطة الوطنية الفلسطينية على توحيد الصف الوطني، و التماســك من أجل إقامة الدولة الفلسطينية المستقلة.

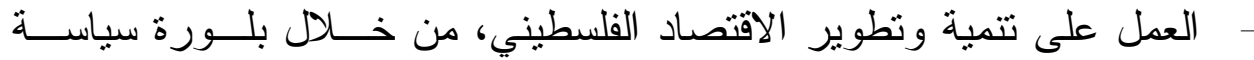

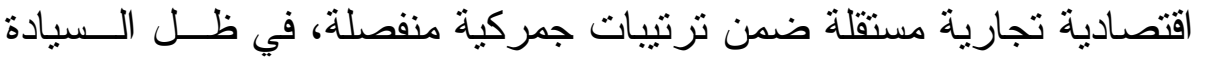




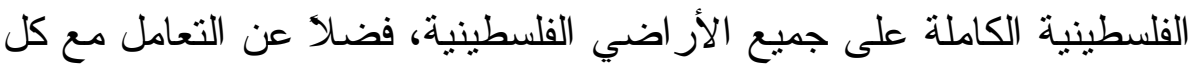

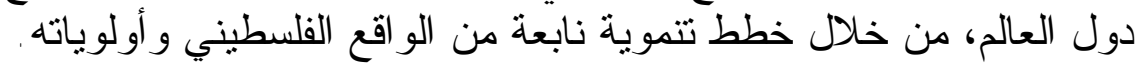

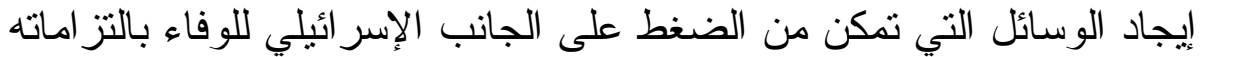

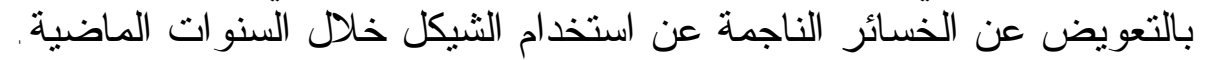

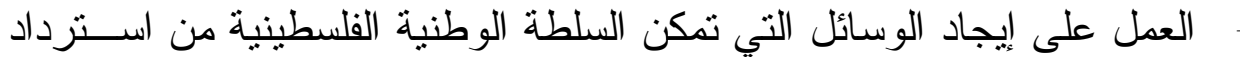

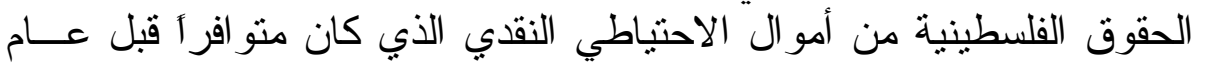

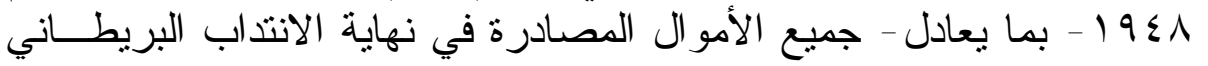
على فلسطين.

\section{r ب ا بلطة النقل الفلسطينية}

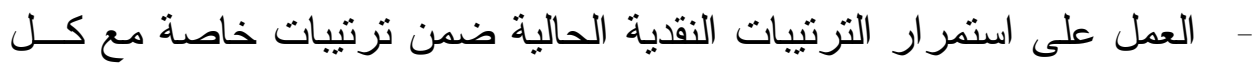
من إسر ائيل، و الأردن بما يضمن الحقوق الفئل الفيطينية.

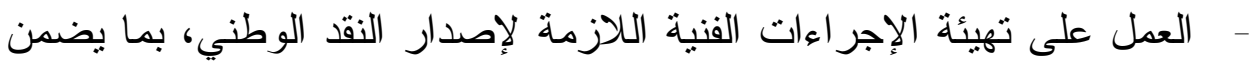

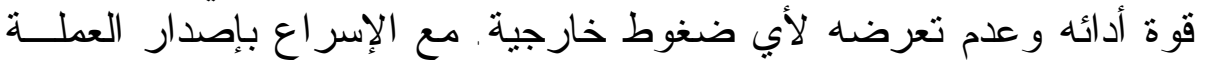

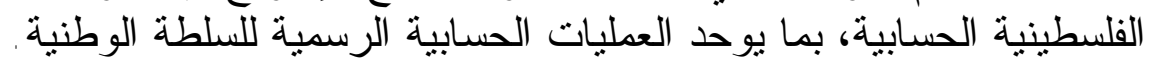

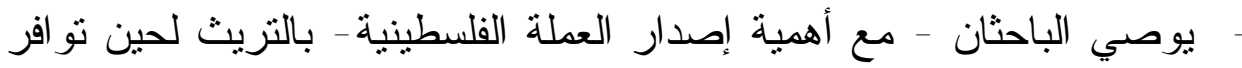

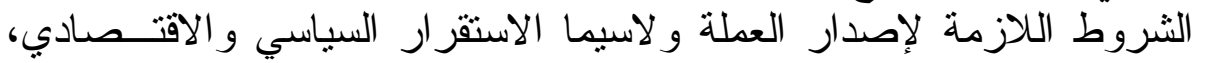
وتطوير النظام المالي و المصرفي.

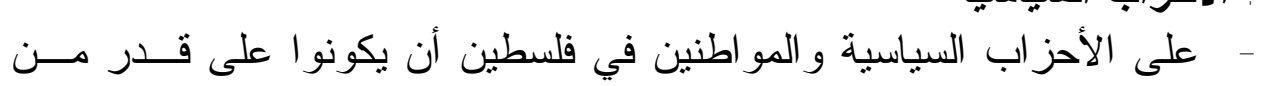

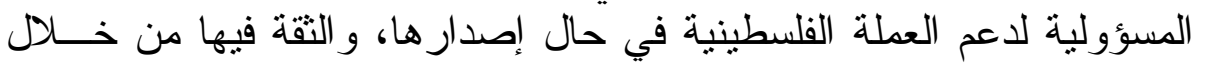

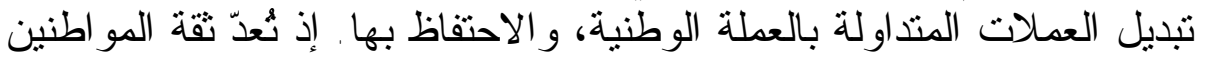
بالتعامل بالعملة المصدرة ذات أهمية في الحفاظ على قيمنها.

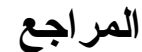 \\ أولاً - المر اجع باللغة العربية}

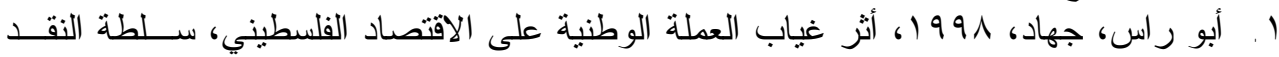

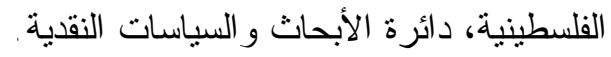

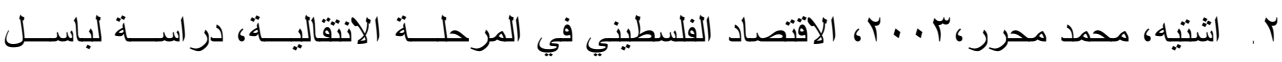

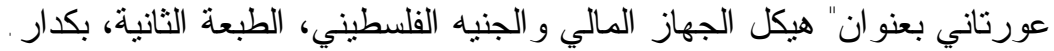

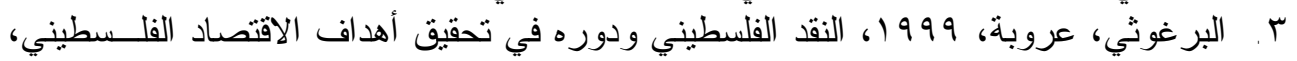
ورقة عمل مقدمة إلى مؤتمر ملامح النظام النقدي الفلسطيني، القاهرة، جامعة الدول الفئ العربية، . $1999 / 11 / 1 \leqslant-14$

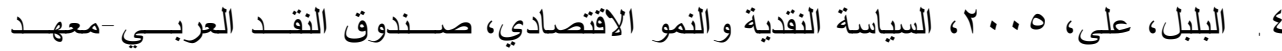

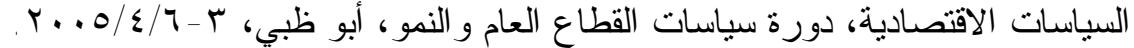

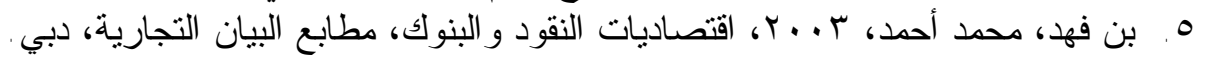


7 . تي سميث، ال. (ف، 999 19، العملة الفلسطينية - دروس مستفادة من مجلس النقد الفلسطيني

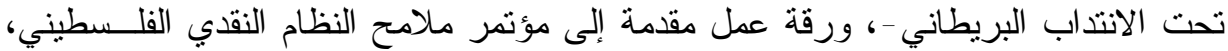

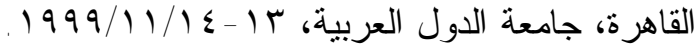

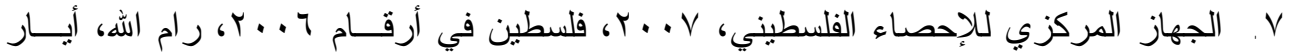
. $r . . V$

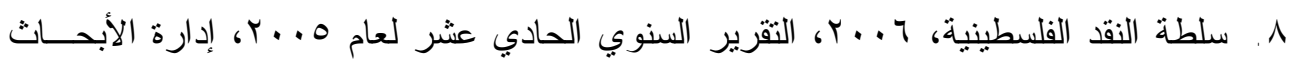

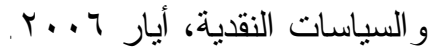

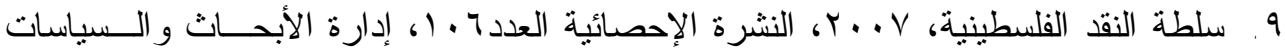

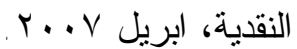

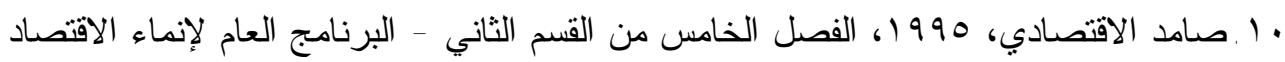

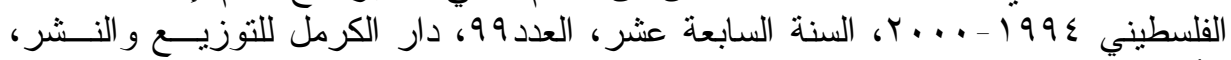

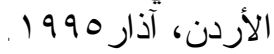
1 (1.صبري، نضال، 1999، القطاع المالي في فلسطين ومتطلبات إصدار العملة، ورقة عمــل

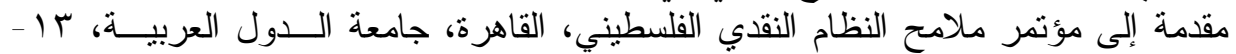
.1999/11/1

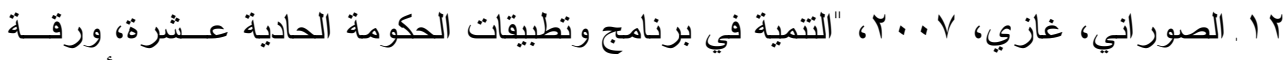

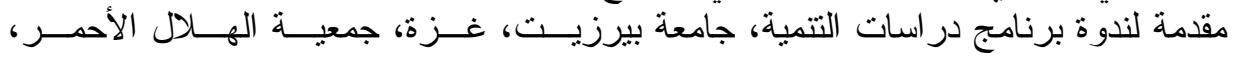
.

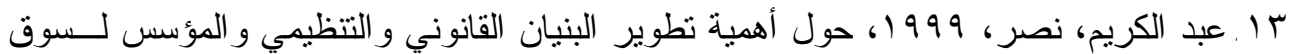

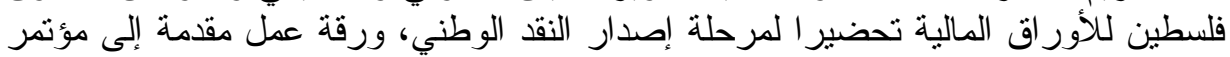

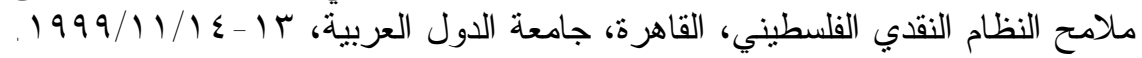

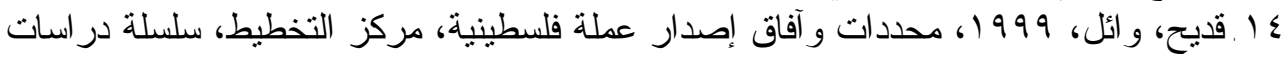

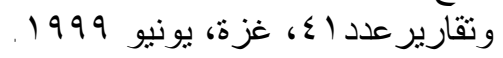

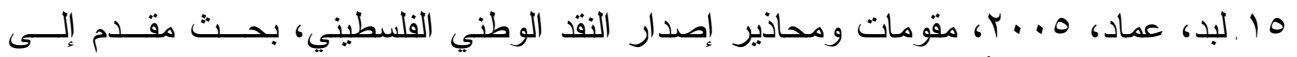

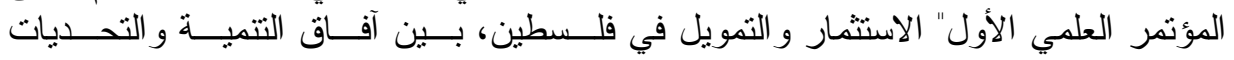

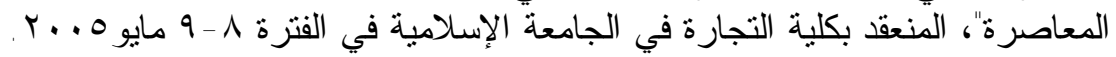

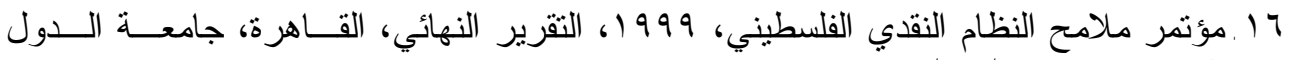

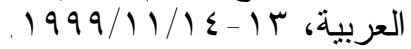

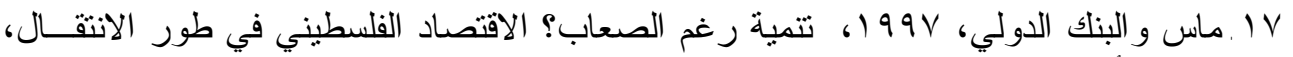

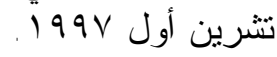

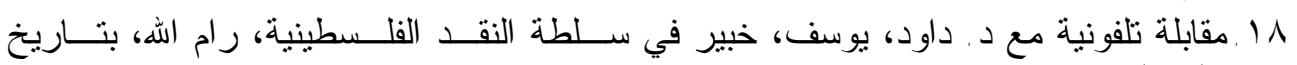
.r..V/l1/

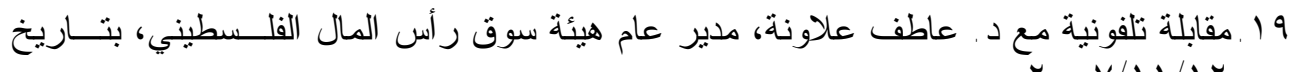
r...V/T/1/T

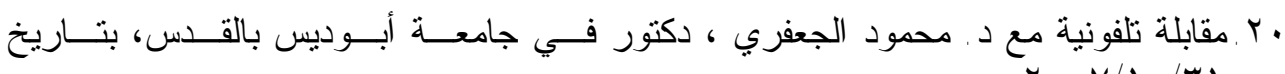
$r+. V / 1 \cdot / T 1$

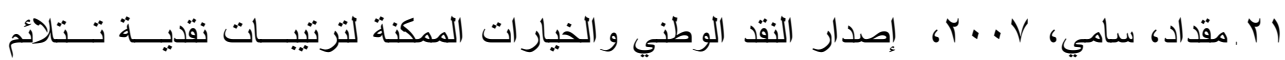

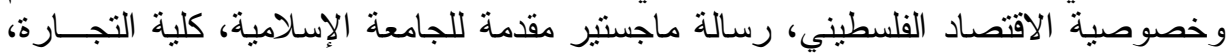
قسم الدر اسات العليا. غزة الأنة 


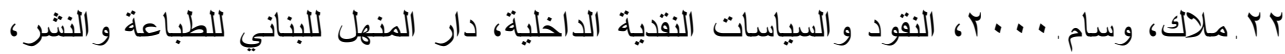
لبنان.

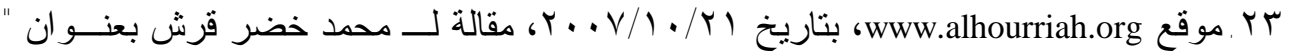

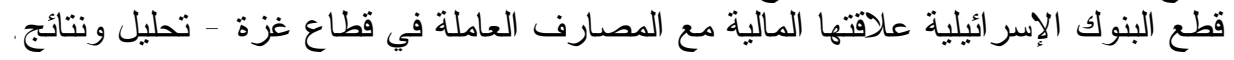
ع ا.بموقع الموقع الالكتروني لوز ارة المالية الفلسطينية.

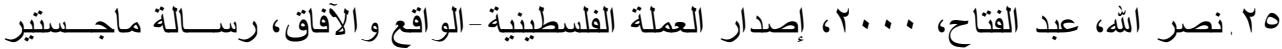

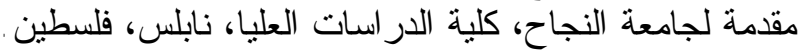

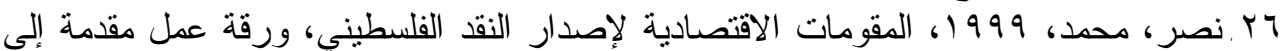

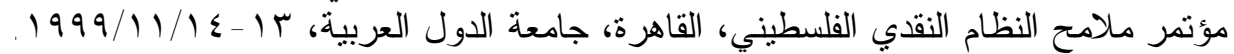

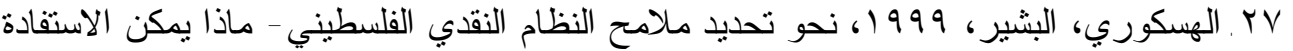

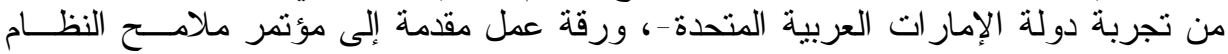

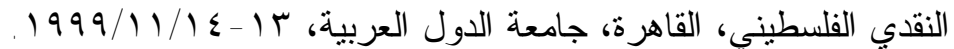

\section{ثاتياً - المر اجع باللغة الأجنبية}

1. Axiltod, Stephen H., 1999, Financial Systems, Regulation, and Monetary Policy Application in Palestine, Cairo, October 1999.

2. Beidas, Samya and Kandil, Magda, 2005, Setting the Stage for National Currency in West Bank and Gaza: The Choice of Exchange Rate Regime, IMF, April 2005.

3. Enrique Co, and Anne-Marie Gulde, 1999, Monetary and Exchange Affairs Department International Monetary Fund, conference of The features of the Palestinian monetary system, Cairo, October 1999.

4. World Bank, 1993, Report of the financial and economic situation in the Palestinian territories, Washington. 